Florida International University FIU Digital Commons

4-13-2017

\title{
Contemporary State Policies Toward Anti- Semitism in Germany and Poland
}

Thomas Just

Florida International University, tjust004@fiu.edu

DOI: $10.25148 /$ etd.FIDC001907

Follow this and additional works at: https://digitalcommons.fiu.edu/etd

Part of the Comparative Politics Commons, Eastern European Studies Commons, International Relations Commons, Policy Design, Analysis, and Evaluation Commons, and the Public Policy Commons

\section{Recommended Citation}

Just, Thomas, "Contemporary State Policies Toward Anti-Semitism in Germany and Poland" (2017). FIU Electronic Theses and Dissertations. 3487.

https://digitalcommons.fiu.edu/etd/3487 


\title{
FLORIDA INTERNATIONAL UNIVERSITY
}

Miami, Florida

\section{CONTEMPORARY STATE POLICIES TOWARD ANTI-SEMITISM IN GERMANY AND POLAND}

\author{
A dissertation submitted in partial fulfillment of the \\ requirements for the degree of \\ DOCTOR OF PHILOSOPHY \\ in \\ INTERNATIONAL RELATIONS \\ by
}

Thomas Just

2017 
To: Dean John F. Stack, Jr.

Steven J. Green School of International and Public Affairs

This dissertation, written by Thomas Just, and entitled Contemporary State Policies

Toward Anti-Semitism in Germany and Poland, having been approved in respect to style and intellectual content, is referred to you for judgment.

We have read this dissertation and recommend that it be approved.

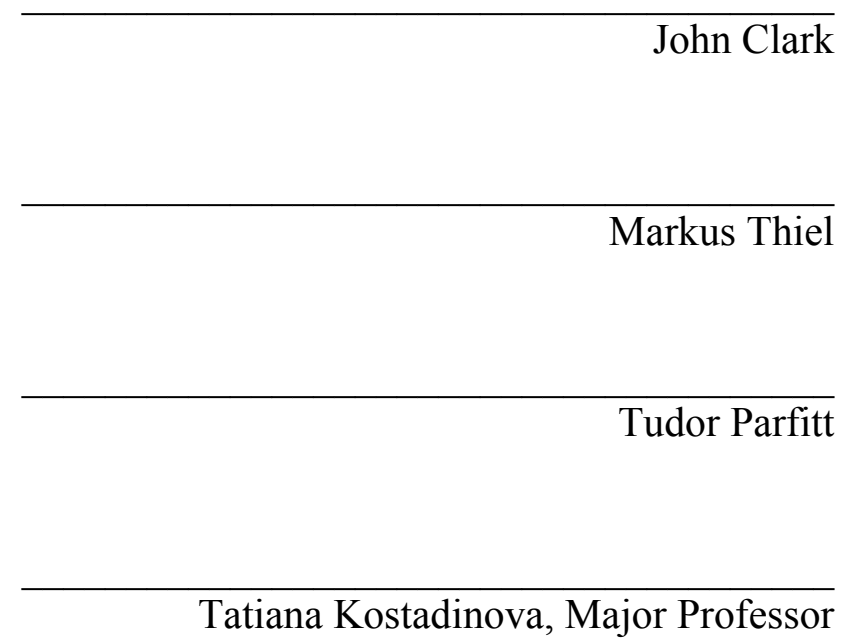

Date of Defense: April 13, 2017

The dissertation of Thomas Just is approved.

Dean John F. Stack, Jr. Steven J. Green School of International and Public

Affairs

Andres G. Gil

Vice President for Research and Economic Development

And Dean of the University Graduate School

Florida International University, 2017 


\section{DEDICATION}

I dedicate this dissertation to the memory of my late grandparents Esther Just and

James Patrick Robertson. Without their love, support, and guidance in life, this

dissertation would not have been possible. 


\section{ACKNOWLEDGMENTS}

I first want to acknowledge my family and friends for their support and sacrifices that allowed me to achieve this goal, especially my parents Thomas Just Sr. and Susie Stone. I also want to thank the members of my committee for their dedication, advice, and encouragement. Dr. Tatiana Kostadinova has been an exceptionally helpful mentor in providing constructive feedback and constantly strengthening my skills as a researcher. Dr. Markus Thiel's regional expertise and advice throughout the writing process has been instrumental in elevating the quality of this dissertation. Dr. John Clark has been a consistently supportive and encouraging presence throughout my doctoral studies. Dr. Tudor Parfitt through his work with the Initiative for Global Jewish Communities and Jewish Museum of Florida-FIU has been an excellent resource who has allowed me to share my research with other students and the community.

I offer a special thanks to Mr. Jonathan Symons and Ms. Sandra Seligman for their generosity and the FIU Graduate School for awarding me a Dissertation Year Fellowship that ensured a timely completion of this manuscript. I am forever grateful to Florida International University and the Department of Politics and International Relations for believing in me and providing me the opportunity to pursue a doctoral degree. 


\begin{abstract}
OF THE DISSERTATION
CONTEMPORARY STATE POLICIES TOWARD

ANTI-SEMITISM IN GERMANY AND POLAND
\end{abstract}

by

Thomas Just

Florida International University, 2017

Miami, Florida

\title{
Professor Tatiana Kostadinova, Major Professor
}

Broadly speaking, this research is intended to shed light on how post-genocide societies attempt to address a traumatic history and reconcile the problems of ethnic and religious hatred. Germany and Poland are especially ripe cases for such research given their historical memories of the Holocaust and unique legal and diplomatic efforts to counter anti-Semitism. However, since many of the policies on this issue have only been implemented in the past ten to fifteen years, there has not yet been a comprehensive study that has evaluated their effectiveness. This dissertation will attempt to fill this gap in the literature and provide new insight as to how states can best grapple with this problem. The central question for this research is: Have state policies been effective in reducing levels of anti-Semitic attitudes and incidents in Germany and Poland since 1990?

This question will be investigated by first examining the historical development of anti-Semitism in each country, then discussing the policies implemented to address the problem, and finally evaluating the results of such measures. From a public policy perspective, this research will contribute to our understanding of the approaches taken by these two countries and discover which measures have been most effective in reducing 
anti-Semitic behavior and ideology. The findings show that while the policies implemented have tended to be effective in reducing general anti-Semitic attitudes and helping revive domestic Jewish communities, they have been less successful in reducing levels of anti-Semitic crime. The policy analysis portions of the dissertation provide a number of explanations for these outcomes and acknowledge areas for potential policy improvement. This research has implications not only for the region of Central Europe, but also other societies that continue to grapple with problems of ethnic and religious hatred. 


\section{TABLE OF CONTENTS}

CHAPTER

PAGE

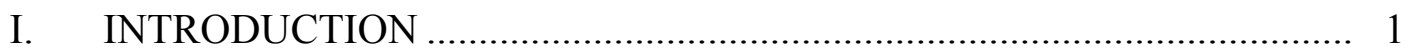

II. THE PROBLEM OF ANTI-SEMITISM IN GERMANY ........................ 21

a. Conceptualizing Anti-Semitism............................................ 21

b. Religious Anti-Semitism in Germany...................................... 35

c. Economic Anti-Semitism in Germany...................................... 41

d. Racial Anti-Semitism in Germany .............................................. 48

e. Political Anti-Semitism in Germany ......................................... 53

III. THE PROBLEM OF ANTI-SEMITISM IN POLAND ............................. 64

a. Religious Anti-Semitism in Poland ............................................ 64

b. Economic Anti-Semitism in Poland............................................. 73

c. Racial Anti-Semitism in Poland.................................................. 81

d. Political Anti-Semitism in Poland ........................................... 86

IV. STATE RESPONSES IN GERMANY ……………………………....... 95

a. Germany's Legal Response ................................................... 96

b. Germany's Public Diplomacy Response ................................. 105

V. STATE RESPONSES IN POLAND ................................................... 126

a. Poland's Legal Response ...................................................... 127

b. Poland's Public Diplomacy Response ...................................... 138

VI. EVALUATING THE EFFECTIVENESS IN GERMANY ...................... 160

a. The Influence of Far Right Groups ........................................ 160

b. Anti-Semitic Attitudes ............................................................ 165

c. Anti-Semitic Attacks and Crimes ............................................... 169

d. Jewish Perceptions and Revival........................................... 176

VII. EVALUATING THE EFFECTIVENESS IN POLAND ......................... 185

a. The Influence of Far Right Groups ....................................... 185

b. Anti-Semitic Attitudes ........................................................... 188

c. Victimhood Competition ........................................................ 198

d. Anti-Semitic Crimes .......................................................... 200

e. Revival of Judaism.............................................................. 205

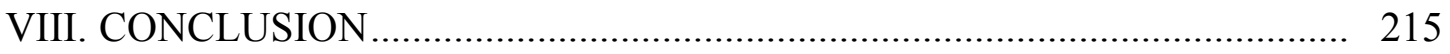

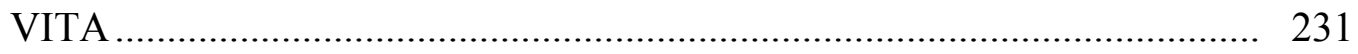




\section{LIST OF TABLES}

TABLE

PAGE

3.1 Actors of Public Diplomacy................................................................... 111

5.1 NPD Landestag Election Results ......................................................... 164

5.2 Violent Anti-Semitic Attacks by Perpetrator in Germany ........................... 173

5.3 Anti-Semitic Crimes by Perpetrator in Germany...................................... 174

5.4 Perceptions of Anti-Semitism by German Jews .................................... 177

6.1 Perceptions of Religious Discrimination (2012) ....................................... 192 


\section{LIST OF FIGURES}

FIGURE PAGE

5.1 Membership in German Far Right Groups (1991-2014) ............................. 161

5.2 Bundestag Election Results for Major Parties with Anti-Semitic Ideologies

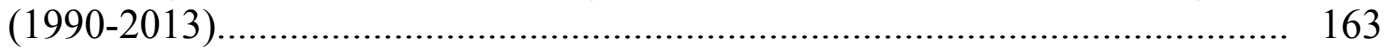

5.3 Percentage of German Population with Anti-Semitic Attitudes (2002-2014).. 166

5.4 Percentage of German Population with Xenophobic Attitudes (2002-2014) ... 167

5.5 Violent Anti-Semitic Attacks in Germany (1991-2015)............................ 170

5.6 Anti-Semitic Crimes in Germany (1991-2014) ........................................ 172

6.1 Sympathy and Antipathy Among Poles Toward Jews (1993-2015).............. 188

6.2 Jews Are Responsible for the Death of Christ (Percentage of Poles Who Agree)

6.3 Jews Use Christian Blood for Religious Purposes (Percentage of Poles Who Agree)

6.4 Jews Have Too Much Economic Influence (Percentage of Poles Who Agree)

6.5 Anti-Semitic Hate Crimes Reported in Poland. 201

6.6 Anti-Semitic Incidents Reported to Polish Authorities 204 


\section{CHAPTER I}

\section{INTRODUCTION}

The problem of anti-Semitism has left deep scars on the history and identity of Central Europe. As the location of the largest genocide in history, memories of the Holocaust continue to remain an important issue in the social and political affairs of Germany and Poland. Numerous groups on the far right and far left, as well as adherents of radical Islamism continue to perpetuate the problem of anti-Semitism. Consequently, the governments of these countries have recently taken steps to respond to this problem, such as making Holocaust denial illegal, granting Judaism legal status on par with Christianity, and facilitating the revival of domestic Jewish organizations. However, there has not yet been a comprehensive study that has evaluated the effectiveness of these efforts. Filling this gap in the literature will be the primary goal of this dissertation.

\section{Research Question}

The central question for this research is: Have state policies been effective in reducing levels of anti-Semitic attitudes and incidents in Germany and Poland since 1990 ? These two countries are especially ripe for such research given their unique efforts on this issue and their historical memories of the Holocaust. The largest genocide in history has in many ways contributed to defining each state's modern identity. Because of this, both states have had increased motivation to address anti-Semitism - not only to reduce crime and violence domestically, but also to improve international perceptions about their respective histories and national identities.

To fully understand and answer this question, the dissertation will first define and conceptualize the terms central to the study - anti-Semitism, public diplomacy, and anti- 
radicalization legal measures. Therefore, the dissertation will begin by engaging the existing literature to further establish clear and concise conceptualizations of these terms that will be operational throughout the following chapters. Second, the dissertation will examine the contemporary history and relationships among anti-Semitic groups in each country to clearly and completely understand the problem that is being addressed. Third, the dissertation will provide a thorough analysis of each state's policies. And finally, the dissertation will evaluate the impacts of such policies on the prevalence and activities of those groups who undertake anti-Semitic activities, as well as the welfare of the respective domestic Jewish communities. These are the necessary components needed to most fully answer the central question of the dissertation.

\section{Significance of the Research}

Broadly speaking, this research is intended to shed light on how post-genocide societies attempt to cope with a traumatic past and evaluate to what extent state policies have been effective in reconciling enduring tensions and conflict. Although the demographics and political dynamics of Europe have changed greatly since the end of the Second World War, the problem of anti-Semitism persists. Many of the policies targeted to combat anti-Semitism have only been implemented since the end of the Cold War, and many within the past ten to fifteen years. Therefore, it has only recently become possible to thoroughly analyze these policies and the consequent effects on the groups and individuals that they concern.

From a public policy perspective, this research will contribute to our understanding of the policies implemented and analyze which have been most effective in reducing levels of anti-Semitism. As anti-Semitism is a social problem, the efforts taken 
to address it often attempt to influence not only behavior, but also attitudes. States tend to use two primary methods in addressing this problem - legal measures and public diplomacy. The legal measures tend to be more focused on punishing particular acts, such as Holocaust denial, spreading anti-Semitic propaganda, or hate crimes. On the other hand, public diplomacy initiatives attempt to influence perceptions and attitudes. By comparing the policies of these two states and analyzing the results, this study will be able to evaluate which approaches and policies tend to achieve the most desirable outcomes.

The issue of anti-Semitism is a rare issue in which public diplomacy initiatives have been launched to specifically address a domestic problem. The theoretical literature on public diplomacy most often focuses on the idea of 'promotion' and emphasizing the positive aspects of a country's culture, political values, and foreign policies, but does not directly address such a situation in which public diplomacy is connected so closely to a domestic problem. These two Central European countries have been rare cases where public diplomacy has been employed to listen and respond to controversial and negative perceptions. The reason for this is that anti-Semitism uniquely affects both a country's domestic environment and the foreign perceptions of the country's identity. As a result of these policies, state relationships with NGOs advocating for Jewish interests are likely to expand, and we expect to observe an increase in the number and funding of Jewish organizations within each country. Whether these resources come directly from the state or private donors, the state is likely to at least have a role in facilitating the growth of these organizations. It is therefore important as a contribution to the field of international 
communication to evaluate the effects of these efforts and whether the findings can be employed in other geographic regions and issues.

The results of this study will shed light on a number of important issues. First, the historical and data analysis portions can be expected to demonstrate the nature of the problem of modern anti-Semitism in Central Europe. Second, the study will produce findings on the state responses to anti-Semitism and provide indications of which elements are likely to be most effective. Third, this study will examine the mechanism that connects the concepts of soft power and public diplomacy, typically viewed only in an international context, to the domestic realm. The findings advance our understanding of the problem of modern anti-Semitism and the ways in which states can most effectively respond. Accomplishing these tasks provide a contribution to the existing literature on both the subjects of anti-Semitism and policy analysis. This research has implications not only for the region of Central Europe, but also other societies that continue to grapple with problems of ethnic and religious hatred.

\section{Literature Analysis}

In order to better understand how this dissertation relates to the existing literature, there are a number of debates and works to consider. First, the theoretical literature on anti-Semitism remains divided as to whether or not contemporary anti-Semitism differs from what could be termed 'classical' anti-Semitism. Second, another literature on the two states in question demonstrates that while Germany and Poland share certain aspects of Holocaust post-memory, there are distinct differences with regard to the contemporary problem of anti-Semitism in each country. And third, an emerging body of literature on 
public responses to the problem offers insight about state policies toward anti-Semitism and the instruments that states can employ in the twenty-first century.

The theoretical literature on anti-Semitism remains divided with regard to defining the term. Much of the recent debate on the issue concerns what has been termed 'new anti-Semitism' - a concept that has been developed by historian Robert Wistrich since the 1970's. Wistrich argues that since the establishment of the State of Israel, antiSemitism and anti-Zionism have become more closely linked. Wistrich's (2010) most recent book entitled A Lethal Obsession: Anti-Semitism - From Antiquity to the Global Jihad examines how anti-Semitism has evolved, and since the establishment of Israel, become more political in nature. Whereas past anti-Semitism tended to focus on theological, cultural, and racial sentiments, Wistrich argues that these prejudices have become increasingly political with attacks on Jews and Jewish symbols occurring often under the guise of opposition to Zionism and the State of Israel. Historian Irwin Cotler (2004) takes a similar view and has categorized 'new anti-Semitism' into nine categories including: genocidal, political, ideological, theological, cultural, and economic antiSemitism, Holocaust denial, anti-Jewish racist terrorism, and international legal discrimination. These scholars represent the range of the theorists who tend to provide a broader definition of anti-Semitism and have come to include certain criticisms of Israel deemed disproportional or delegitimizing as anti-Semitic.

Other scholars, such as Brian Klug (2004), argue that the notion of 'new antiSemitism' is confused and that the term has become too encompassing of critiques of Israel. Klug argues that definitions such as that of Wistrich may even 'water down' the term anti-Semitism as it comes to include 'new' elements. Klug contends that there is 
nothing 'new' about anti-Semitism in the twenty-first century, but rather there is a continuation of a 'classical anti-Semitism' and stereotypes of Jews that have endured. Moreover, Klug claims that one must clearly differentiate hostility toward Israelis from hostility toward Jews, because criticisms or hostility toward Israelis is not necessarily the same thing as anti-Semitism. As he writes, "When anti-Semitism is everywhere, it is nowhere. And when every anti-Zionist is an anti-Semite, we no longer know how to recognize the real thing - the concept of anti-Semitism loses its significance" (Klug 2004).

The problem of anti-Semitism in Germany has a long and well-documented history. However, scholars are careful to distinguish between different forms of antiSemitism. Paul Rose (1992) chronicles the history of anti-Semitism in Germany and argues that anti-Semitism in medieval times, reflected by the attitudes of such figures as Martin Luther, was primarily driven by theological motives, whereas modern antiSemitism has taken on a more racial tone. Christian Davis (2012) argues a similar point to Rose, but contends that these racial tones of anti-Semitism originated in German procolonial movements around the time of the modern German state in 1871. Davis goes on to argue that the nationalist sentiment within the pro-colonial movements emphasized a sense of German racial superiority, which attracted anti-Semitic political parties and organizations to the movement, eventually forming the basis for National Socialist ideology. Clemens Heni (2012) points out that contemporary anti-Semitism also has a more nuanced element, in which some groups trivialize the Holocaust and other past persecutions of Jews. Heni argues that trivializing these parts of history is common 
among groups of various political leanings and is a primary reason why many antiSemitic groups and movements are able to endure.

While the history of anti-Semitism in Germany is commonly associated with National Socialism and groups on the far right, many scholars point out that antiSemitism is not isolated to these groups. There is indeed a history of groups with antiSemitic beliefs coordinating with one another. The relationships among the far right and Islamic groups are complex, but there is literature that has explored the ways in which common anti-Semitic views have united elements of each movement. Klaus Gensicke's (2007) book Der Mufti von Jerusalem und die Nationalsozialisten examines this relationship dating back to the origins of the Third Reich with a particular focus on the role of the Grand Mufti of Jerusalem. Gensicke chronicles the manner in which Nazi officials attempted to appeal to Muslim populations, often on anti-Semitic grounds, and even recruited Muslim soldiers in some cases. Ian Johnson's (2010) book A Mosque in Munich: Nazis, the CIA and the Rise of the Muslim Brotherhood in the West follows this relationship during the Cold War and the ways in which the anti-Semitic propaganda of the far right and Islamism often overlaps. Johnson also illustrates cases in which former Nazi officials converted to Islam after the war and their various reasons for doing so. Robert Wistrich's (2010) work in A Lethal Obsession explores similar themes, but also includes an examination of anti-Semitism among leftist groups such as the Baader Meinhof Group and others. Günther Jikeli (2015) provides a more focused analysis on Muslim anti-Semitism in Europe specifically, and examined the role of Middle East conflict and Islamist ideology in perpetuating this problem. Jikeli argues that there has been a certain normalization of anti-Jewish hostility among some of these ideological 
groups, many of whom tend to reside in immigrant communities that are often not well assimilated with the native populations. Understanding these relationships and ideologies is important to defining the problem of anti-Semitism in Central Europe, and particularly within Germany, which has a sizable and growing Muslim population.

Scholars who have examined anti-Semitism in Poland have noted many common elements of history with the German case, but also emphasize a number of social and historical differences. Theodore Weeks (2005) acknowledges a history of religious tolerance that led many Jews to settle in Poland, but argues that attempts to assimilate Jews into the predominantly Polish Catholic society created friction between the two groups. Weeks argues that attempts were made to assimilate all Polish residents in order to deter threats from abroad, but that these attempts led to a backlash of nationalist and anti-Semitic sentiment and the idea of assimilation became replaced by more exclusionary and aggressive ideologies. Hillel Levine (1993), on the other hand, argues that the roots of anti-Semitism in Poland stem from economic grievances and a scapegoating of the Jewish population, which traces back to at least the eighteenth century. Levine contends that the demise of the Polish state in 1795 was often blamed on an inability to develop socially, economically, and politically and that Jews were often blamed for these failures to modernize, which led to an economically motivated antiSemitism that has persisted ever since. Ronald Modras (2000) acknowledges the economic aspects of anti-Semitism, but argues that there is often a deeper theological and nationalist motivation. Modras points out that the myth of a Masonic-Jewish alliance (originating in France) expanded to Poland in the 1930's and has been viewed by some Polish nationalists as a threat to their vision of a Polish Catholic state since. Just as in the 
case of Germany, scholars present a number of perspectives on the origins and strains of anti-Semitism that have emerged and persisted throughout history.

The literature on contemporary anti-Semitism in Poland points to a few important social and political factors in defining the problem and how it has developed. In his book Fear: Anti-Semitism in Poland After Auschwitz, Jan Gross (2007) chronicles the persecution of Jewish groups under the communist regime, as well as the variety of attitudes toward Jews within Poland after the Holocaust. In particular, Gross focuses on how Poland's communist rulers tended to use anti-Semitism as a means of political expediency and to placate Polish nationalist factions. Genevieve Zubrzycki's (2006) book The Crosses of Auschwitz: Nationalism and Religion in Post-Communist Poland builds on these themes and examines the ways in which social conflicts regarding anti-Semitism have continued into the post-Cold War period. Zubrzycki explores the struggle that Poland has undergone during this period with regard to establishing a renewed national identity and coping with its historical memory of the Holocaust. She describes the unease that some ultranationalist factions have with incorporating Jewish elements of history into this renewed Polish identity.

Another body of literature offers insights about the state policies toward antiSemitism. The first topic that these works examine are the legal policies addressing the problem. Stephen Atkins (2009) describes that bans against Holocaust denial have become one of the primary methods that states have employed to combat anti-Semitism and explains that the goal of these policies is to prevent rational thinkers from becoming vulnerable to fringe ideas. However, Atkins points out that the transnational nature of the Holocaust denial movement creates difficulty in terms of having an impact on the 
movement's information links. Christine Shavers (2014) examines hate crime policies in different countries, including Germany, and questions whether social motivations or attitudes can adequately supplement existing law. Shavers identifies numerous weaknesses in these laws, such as establishing a burden of proof for motivation and ensuring equal application of the law. Shavers' claims that an inability to consistently prosecute hate crimes and the extensive investigation resources necessary to demonstrate the bias of the perpetrator are challenges that limit the effectiveness of these policies. Similarly, Kimberly Potter (2000) argues that hate crimes laws suffer from a lack of clear and consistent goals. Potter contends that the majority of hate crimes do not result in arrests or prosecution, in part because of an inherent difficulty in merging social concern with legal definitions. She goes on to argue that prosecutions become more complex when perpetrators are minorities themselves. However, Potter does acknowledge that investigating hate crimes may provide some social benefit in terms of identifying particular crimes as such.

The literature on state policies regarding anti-Semitism also identifies public diplomacy initiatives as a second method for addressing the problem. Joseph Nye, one of the foremost scholars in the field, contends that "the soft power of a country rests primarily on three resources: its culture, its political values, and its foreign policies" (2008: 97). One could argue that reports of anti-Semitism damage all three elements of a country's soft power, especially in the twenty-first century 'information age.' Beata Ociepka and Marta Ryniejska's (2005) article entitled "Public Diplomacy and EU Enlargement: The Case of Poland" argues that international perceptions and attitudes are largely shaped by second hand experiences, media coverage, and information from 
schools or informal groups. Consequently, they argue that international communication and public diplomacy become imperative with regard to addressing stereotypes and controversial subjects. The Polish government has even stated openly the importance of public diplomacy to its policies targeting anti-Semitism by writing, "Symmetric dialogue in Polish-Jewish relations is an essential part of the Polish public diplomacy. This important communication tool is used not only by governments, but also in the public spheres of individual states, whose important components are Jewish NGOs and institutions, as well as opinion-making circles within the Jewish diaspora" (Polish Ministry of Foreign Affairs, 2011). These comments demonstrate a level of governmental and non-governmental cooperation for a common purpose. Zubrzycki's (2012) work even describes a 'Jewish revival' that has taken place, in part due to an increased emphasis on Polish-Jewish relations and Poland's attempts to redefine its national identity in the postcommunist era.

\section{Gaps in Current Literature}

Overall, while academic research on the problem of anti-Semitism in Central Europe in the twentieth century is quite abundant, there is a lack of literature studying the problem in the twenty-first century and the contemporary state responses. The dissertation will seek to answer some of the questions that remain. The three most pressing areas that require further examination are as follows:

First, there is a lack of agreement on what constitutes anti-Semitism. Active debate continues on the nature of anti-Semitism and how the concept in the twentieth century differs from the concept of today. The arguments of Wistrich and Klug differ with regard to what extent anti-Israel sentiment can constitute anti-Semitism. This issue 
has become increasingly important in the twenty-first century and is in need of further analysis.

Second, the academic literature covers a number of important relationships between different groups that share anti-Semitic views. However, this research is in need of updating due to the changing demographics and political dynamics in the twenty-first century. The current literature explores the relationships between far right, far left, and Islamic groups that share anti-Semitic views dating back to before the Holocaust and through the Cold War. These works are helpful in understanding the origins of the problem of anti-Semitism, but it remains unclear to what extent these relationships and the prevalence of anti-Semitism among elements of these groups have continued into the twenty-first century.

Third, while there is some academic literature on the manner in which the populations and remaining Jewish communities in Central Europe have attempted to cope with historical memories of the Holocaust, these analyses tend to be from a sociological perspective lacking sufficient mention of the role the state has played in these processes. Zubrzycki's work has touched on the subject in the case of Poland, but her analysis focuses primarily on non-governmental actors. The theoretical literature on public diplomacy and soft power would suggest that the state has an interest in addressing the controversial aspects of each country's history in order to construct a positive postcommunist era identity and establish credibility as a modern, tolerant society. However, the literature has thus far neglected to make adequate mention of how the concepts of soft power and public diplomacy connect to the domestic society. 


\section{Theoretical Framework}

In order to most fully and accurately answer the central research question of this study, we will first define and conceptualize two of the key terms that will be used throughout - anti-Semitism and public diplomacy. The simple definition of antiSemitism, as defined by the Merriam-Webster Dictionary, is a "hostility toward or discrimination against Jews as a religious, ethnic, or racial group” ('Anti-Semitism’ 2015). In order to conceptualize the term further, we emphasize that the term antiSemitism denotes prejudice, hatred, or discrimination against Jews individually or as a group. Anti-Semitism often, but does not always, involve the urging of violence or use of dehumanizing rhetoric against Jews. Such rhetoric may be used in the context of denigrating Jewish culture, ethnicity, or religion. Anti-Semitism may also be manifested in arguments involving Holocaust denial and conspiracy theories that scapegoat Jews and depict them as plotting to undermine society, as for example in texts such as The Protocols of the Elders of Zion. As Brian Klug (2004) argues, anti-Semitism does not include all geopolitical critiques of the State of Israel, although the two can be related when such critiques involve physical or rhetorical attacks on Jews or Jewish symbols.

One of the earliest and most widely accepted definitions of public diplomacy was defined by Edmund Gullion as "the means by which governments, private groups and individuals influence the attitudes and opinions of other peoples and governments in such a way as to exercise influence on their foreign policy decisions" (Murrow Center for Public Diplomacy, 2015). In other words, public diplomacy can be described as diplomacy that takes place outside of traditional government-to-government information channels. Such initiatives often include governmental agencies building long-term 
relationships with non-governmental organizations and even individuals for the purposes of distributing messages and creating favorable perceptions.

However, it is important to distinguish between public diplomacy and propaganda. Propaganda and mere public relations campaigns often lack credibility and are aimed at short-term goals, whereas public diplomacy involves long-term relationship building aimed at conveying information and a positive image. As Joseph Nye explains, "Simple propaganda often lacks credibility and thus is counterproductive as public diplomacy" (2008: 101).

Nation branding is an element, or some may say a new method, of conducting public diplomacy that is pertinent to this study. Nation branding is closely related to commercial branding, because both aim to attract support for a particular product, which in the case of nations can be their culture, political ideals, or policies. Both Germany and Poland have embarked on creating renewed national identities in the post-Cold War period and have developed nation-branding strategies of their own. As Peter van Ham describes, "branding has become essential to create value in the relationship between territories and individuals" (2008: 128). This relationship, however, is not merely between one territory and populations outside that territory, but also those within the territory. Peter van Ham goes on to argue that "place branding is also required to make a country's image work for its economy and its citizens" (2008: 128). Such a statement invokes the idea that place or nation branding inherently has a mechanism that is connected to not only external, but also internal, populations. The cases of Germany and Poland and their respective responses to anti-Semitism are two cases where this phenomenon is perhaps best exemplified. 
Before we can begin to understand state policies toward anti-Semitism, we will first need to define the problem and outline its dimensions and magnitude. In order to do so, we will examine the historical and modern context of the problem in both Germany and Poland. This portion of the dissertation will engage closely with the existing literature regarding the different strains of anti-Semitism discussed by Rose (1992), Davis (2012), Heni (2012), Weeks (1995), Levine (1993), and Modras (2000). This section will also examine and build upon the works of Gensicke (2007), Wistrich (1985; 2004; 2010), Gross (2007), and Zubrzycki (2006; 2012) among others. These and other works will help inform our study of anti-Semitic groups, the relationships between them, and their relevant similarities and differences. By defining the problem early in the dissertation, this will allow us to later examine how well connected the responses and policies are to the problems that they intend to solve and in which areas there is a certain dissonance.

Second, this study will explain the state responses to the problem. The literature describes two primary ways in which states have attempted to address the problem of anti-Semitism - legal measures and public diplomacy. This section will examine the legal measures that the German and Polish governments have employed to combat antiSemitism, such as placing bans on Holocaust denial and radical political parties, as well as hate crimes legislation. The section will also examine the public diplomacy initiatives implemented by Germany and Poland and the relationships that the states have created with non-governmental entities for the purpose of addressing anti-Semitism. This discussion will include an analysis of the strategy employed and the resources allocated as part of this approach. This section will build upon the theoretical literature of Nye (2008), van Ham (2008), Olins (2000), and Ociepka and Ryniejska (2005) and 
demonstrate that public diplomacy strategies have been used to address a domestic problem in this case. Nye and van Ham have written on the importance of credibility to a state's overall public diplomacy, and we will argue that credibility is the mechanism that connects public diplomacy to the domestic society in these cases.

Third, this study will evaluate the effectiveness of the state responses. The literature from Jikeli (2015) and Wistrich (2010) suggests that states are likely to have greater difficulty in affecting anti-Semitic attitudes among immigrant and non-citizen populations than native-born and citizen populations. The logic behind this argument is that immigrants and non-citizens tend to be less engaged in civil society and political institutions, and thus are less likely to be impacted by public policy initiatives carried out through such institutions. Therefore, there are likely to be differences in the effects on immigrant, native-born, citizen, and non-citizen populations.

Additionally, the effects of policies regarding anti-Semitism will likely not only have impacts on anti-Semitic groups, but also the welfare of domestic Jewish communities. Zubrzycki (2012) claims that Poland has experienced a Jewish revival in the post-communist era; however, she leaves the reasons for this revival rather ambiguous. If Zubrzycki's claims are indeed accurate, it will be important to provide an explanation for this phenomenon. The increased emphasis on public diplomacy initiatives may provide one such explanation. As public diplomacy initiatives by definition engage non-governmental actors and organizations, it is likely that more resources have been allocated toward Jewish groups as part of the state responses to anti-Semitism. Therefore, it will be worth examining to what extent these approaches have influenced the presence and vibrancy of Jewish communities in each country. 


\section{Composition and Structure of the Dissertation}

\section{Chapters 2 and 3: The Problem of Anti-Semitism}

The goal of these chapters will be to explain the ways in which the problem of anti-Semitism tends to manifest in Germany and Poland, as well as provide analysis of the groups most responsible for the problem. The chapter will begin by conceptualizing the term anti-Semitism and establishing an operational definition. This includes engagement with the historical and theoretical literature on the subject. These chapters will primarily be organized to explain the four primary strains of anti-Semitism that have developed within each country over time. By examining the strains of religious, economic, racial, and political anti-Semitism, one will be provided with an historical understanding of the problem in each country over time.

\section{Chapters 4 and 5: The State Responses}

The goal of these chapters will be to explain the policy mechanisms that the German and Polish states have employed to respond to the problem of anti-Semitism. This will include a discussion of the laws and public diplomacy initiatives that have been implemented in each country. This discussion will be informed by a detailed analysis of the governmental and non-governmental institutions tasked with leading and implementing the approach. Special attention will be paid to the ways in which the relevant states have attempted to connect their policies with problems specific to their country.

\section{Chapters 6 and 7: The Effectiveness of the State Responses}

The goal of these chapters will be to evaluate the policy successes and failures in Germany and Poland. In order to accomplish these goals, we will present and analyze the 
data relevant to each case over time. This will require a thorough analysis of the effects that the policies have had on different anti-Semitic groups, attitudes, and incidents. These chapters will also examine the welfare of the domestic Jewish community in each country.

\section{Chapter 8: Conclusion}

The goal of the concluding chapter will be to summarize the major findings of the dissertation and provide a concise answer to the central research question. This chapter will also explain the implications of this research for policymaking and describe potential avenues for further research.

\section{References}

'Anti-Semitism' (2015). Merriam-Webster Dictionary. http://www.merriamwebster.com/dictionary/anti-semitism, accessed 28 February 2015.

Atkins, Stephen (2009). Holocaust Denial as an International Movement. Santa Barbara: Praeger.

Black, Edwin (2009). The Transfer Agreement: The Dramatic Story of the Pact between the Third Reich and Jewish Palestine. New York: First Dialog.

Breitman, Richard and Norman Goda (2011). Hitler's Shadow. Washington D.C.: U.S. National Archives.

Browning, Christopher R (2007). The Origins of the Final Solution: The Evolution of Nazi Jewish Policy. Lincoln, Nebraska: University of Nebraska Press.

Cotler, Irwin (2004). Human Rights and the New Anti-Jewishness. Front Page Magazine. 16 February: http://archive.frontpagemag.com/readArticle.aspx?ARTID=14162, accessed on 10 April 2015.

Davis, Christian (2012). Colonialism, Anti-Semitism, and Germans of Jewish Descent in Imperial Germany. Ann Arbor: University of Michigan Press.

Gensicke, Klaus (2007). Der Mufti von Jerusalem und die Nationalsozialisten.

Darmstadt: Wissenschaftliche Buchgesellschaft. 
Gross, Jan (2007). Fear: Anti-Semitism in Poland After Auschwitz. New York: Random House.

Heni, Clemens (2012). Anti-Semitism: A Specific Phenomenon. Berlin: Edition Critic.

Hoare, Marko Attila (2013). The Bosnian Muslims in the Second World War: A History. London: C. Hust and Company.

Jikeli, Günther (2015). European Muslim Anti-Semitism: Why Young Urban Males Say They Don't Like Jews. Bloomington: Indiana UP.

Johnson, Ian (2010). A Mosque in Munich: Nazis, the CIA and the Rise of the Muslim Brotherhood in the West. Boston, Massachusetts: Houghton Mifflin Harcourt Publishing.

Klug, Brian (2004). The Myth of the New Anti-Semitism. The Nation. 15 January: http://www.thenation.com/article/myth-new-anti-semitism\#, accessed on 21 March 2015.

Kulczycki, John (2005). Eastern Europe in Western Civilization Textbooks: The Example of Poland, The History Teacher 38 (2): 163-167.

Lepre, George (1997). Himmler's Bosnian Division; The Waffen-SS Handschar Division 1943-1945. Atglen, Pennsylvania: Schiffer Publishing.

Levin, Nora (1968). The Holocaust: The Destruction of European Jewry 1933-1945. New York: Thomas Y. Crowell Company.

Levine, Hillel (1993). Economic Origins of Anti-Semitism: Poland and Its Jews in the Early Modern Period. New Haven: Yale UP.

Lewis, Bernard (2002). The Jews of Islam. Santa Barbara, California: Greenwood Publishing Group.

Liang, Christina Schori (2013). Europe for the Europeans: The Foreign and Security Policy of the Populist Radical Right. Farnham, UK: Ashgate.

Modras, Ronald (2000). The Catholic Church and Anti-Semitism. London: Routledge.

Murrow Center for Public Diplomacy (2015). Definitions of Public Diplomacy. Tufts University, http://fletcher.tufts.edu/murrow/diplomacy/definitions, accessed 25 March 2015. 
Ociepka, Beata and Marta Ryniejska (2005). "Public Diplomacy and EU Enlargement: The Case of Poland." Netherlands Institute of International Relations: http://www.clingendael.nl/sites/default/files/20050800_cli_paper_dip_issue99.pdf , accessed on 15 March 2015.

Olins, Wally (2000). Trading Identities: Why Countries and Companies Are Taking on Each Others' Roles. London: Foreign Policy Centre.

Polish Ministry of Foreign Affairs (2011). Public Diplomacy 2011, http://broszury.msz.gov.pl/dp_en/, accessed 17 March 2015.

Potter, Kimberly (2000). Hate Crimes: Criminal Law and Identity Politics. Oxford: Oxford UP.

Nye, Joseph (2008). Public Diplomacy and Soft Power. Annals of the American Academy of Political and Social Science 616.

Rose, Paul (1992). Revolutionary Anti-Semitism from Kant to Wagner. Princeton UP.

Shavers, Christine (2014). Criminal Law Dealing with Hate Crimes: Functional Comparative Law, Germany vs. USA. Bern: Peter Land GmbH.

van Ham, Peter (2008). Place Branding: The State of the Art, Annals of the American Academy of Political and Social Science 616: 126-149.

Weeks, Theodore (2005). From Assimilation to Anti-Semitism: The "Jewish Question" in Poland, 1850-1914. DeKalb: Northern Illinois UP.

Wistrich, Robert S. (1985). Hitler's Apocalypse: Jews and the Nazi Legacy. London: Weidenfeld \& Nicolson.

Wistrich, Robert S. (2004). The Politics of Resentment: Israel, Jews and the German Media. Jerusalem: Hebrew University of Jerusalem. SICSA Report no. 23.

Wistrich, Robert S. (2010). A Lethal Obsession: Anti-Semitism - From Antiquity to the Global Jihad. New York: Random House.

Zubrzycki, Genevieve (2006). The Crosses of Auschwitz: Nationalism and Religion in Post-Communist Poland. Chicago: University of Chicago Press.

Zubrzycki, Genevieve (2012). Religion, Religious Tradition, and Nationalism: Jewish Revival in Poland and 'Religious Heritage' in Quebec, Journal for the Scientific Study of Religion 51 (3): 442-455. 


\section{CHAPTER II}

\section{THE PROBLEM OF ANTI-SEMITISM IN GERMANY}

\section{a. Conceptualizing Anti-Semitism}

Anti-Semitism is most commonly defined as "hostility toward or discrimination against Jews as a religious, ethnic, or racial group” ('Anti-Semitism’2015). Such a definition conveys the broad nature of the term; however, a better understanding of its meaning requires examination of the ways in which anti-Semitism tends to manifest. Throughout history, there have been various strains of anti-Semitism based on religious, economic, racial, and political grounds. Each of these strains tends to carry distinct, yet often related forms of discrimination, stereotypes, and hatred. The term becomes even more complex when considering the ways in which these strains and manifestations have evolved over time. In order to more fully conceptualize the term anti-Semitism, this section will examine each of these strains, as well as analyze the historical development of the term. Particularly important to this discussion will be the scholarly debate as to whether or not contemporary anti-Semitism significantly differs from what is often termed classical anti-Semitism. This section focuses on conceptualizing anti-Semitism and serves to aid in defining the problem within the relevant case studies.

\section{Religious Anti-Semitism}

Many historians regard religious anti-Semitism as the oldest manifestation dating back to the ancient Greeks in the third century BCE. The origins of anti-Semitism are often traced to the Jews' refusal to adopt Greek religious and social practices. A number of historians of this era depicted the religious practices of Jews as absurd and inhospitable. The influential writings of Egyptian historian Manetho depicted the exodus 
of the Jews from Egypt not as a revolt against an oppressive Pharoah, but as lepers who needed to be removed from society. Greek historian Agatharchides similarly depicted Jews as weak by arguing that their "irrational" religious practices left them especially vulnerable to conquest (Flannery, 1985: 11-12).

Religious anti-Semitism evolved as early Christians placed heavy blame on Jews for the crucifixion of Jesus - an accusation of deicide. Some of this was fueled by New Testament writings, such as "the Jews who killed the Lord Jesus and the prophets and also drove us out. They displease God and are hostile to everyone" (1 Thessalonians 2:14-15). Scholars differ as to the precise meaning and background of such passages, but these passages have nonetheless played a role in Christian-Jewish tensions throughout history. Because of this, Jews were often portrayed as representing the devil in medieval European paintings, restricted to socially inferior occupations, and subjected to blood libels (Cohen, 2007: 208). Certain Christian thinkers, such as Martin Luther, perpetuated anti-Semitic beliefs by describing Jews as "base, whoring people, that is, no people of God" and "full of devil's feces" (Luther, trans. 1971: 20) (Michael, 2006: 113). Such religiously based manifestations of anti-Semitism have been a point of tension between Christians and Jews, particularly in Europe, for millennia.

It is, however, a bit more difficult to pinpoint the religious origins of Islamic antiSemitism. Unlike in Christian texts, the Quran does not accuse Jews of deicide. Thus, the religious nature of anti-Semitism in Islam does not originate from the same source as in Christianity. Although there are indeed negative depictions of Jews in Islamic texts, these depictions are not universal. Islamic tradition regards Jews as a legitimate community of believers in God or "people of the Book," as both religions are monotheistic Abrahamic 
faiths (Kramer, 1995). An important distinction between Christian and Islamic antiSemitism is that while Christian anti-Semites have historically viewed Jews with fear, Muslim anti-Semites have historically viewed Jews with ridicule (Lewis, 1999: 192). Whereas Christians have at times persecuted Jews due to allegations of deicide, Muslims have at times condemned Jews for their refusal to recognize Mohammed as God's prophet - a different, and arguably less serious charge (Laqueur, 2006: 191-192).

Negative depictions of Jews in Islam tend to focus on the characteristic of humiliation. Some Islamic texts depict Jews as a humiliated group due to their perceived disobedience to God's law. This is evident in such passages as the following: "They (the children of Israel) were consigned to humiliation and wretchedness. They brought the wrath of God upon themselves, and this is because they used to deny Allah's signs and kill His Prophets unjustly" (Sura 2:61). Muhammad's own relationships with Jews are known to have been mixed. While Muhammad was known to have had Jewish friends and one Jewish wife, who later converted to Islam, He also engaged in numerous battles with Jewish tribes (Poliakov, 1974: 41-43). Jewish defeats in such battles are commonly cited as an additional reason for Jews being viewed as a submissive, humiliated group (Lewis, 1999: 129-130). Therefore, while there are indeed strains of religious antiSemitism in both Christianity and Islam the sources and points of emphases tend to differ between these religious traditions - with Christian anti-Semitism focusing on deicide and blood libel and Islamic anti-Semitism focusing on humiliation and disobedience.

\section{Economic Anti-Semitism}

In medieval Europe, Jews were often restricted to occupations considered socially inferior to Christians, such as tax collecting and moneylending. This was in large part due 
to Christian doctrine of the time that considered charging interest on loans to be sinful - a belief that continues in certain Islamic societies. One reason that Jews were allowed to engage in moneylending, although considered a sinful activity, was that Jews were already considered to be damned. Moreover, by Jews filling these occupations this would save the souls of Christians who would otherwise take on such roles (Todeschini, 2004: 11) (Penslar, 2001: 18). This situation caused Jews to carry a stigma of being unproductive, parasitic, usurious, dishonest, dangerous, and so on (Schweitzer and Perry, 2002: 133).

By the eighteenth century, some estimate that as many as three fourths of Jews in Central and Western Europe were involved in moneylending occupations (Sachar, 2005). Later, Jewish Emancipation in the nineteenth century allowed European Jews to engage in a wider variety of occupations, including law and medicine (Perry, 2002: 136). Nonetheless, the medieval stigma of Jews as sinful, dishonest, and usurious continued and became the basis for a number of anti-Semitic stereotypes and canards. These stereotypes tend to portray Jews as stingy, greedy, controlling, and wealthy. The canards often depict powerful Jews as being controlling over the business world and a scapegoat for gentile hardship, such as in The Protocols of the Elders of Zion.

Remarkably, economic anti-Semitism has been used to accuse Jews of being responsible for the ills of both capitalism and communism. In fact, Karl Marx singled out Jews and claimed that since many worked in what he considered "non-productive" occupations that they could be blamed for a great deal of exploitation and alienation of workers (Perry, 2002: 153-156). Marx even went so far as to argue that Jews embodied capitalism, because, according to him, Jewish culture shared elements of materialism and 
egoism that he also attributed to capitalism (Penslar, 2001). Marx wrote that, "Because of Judaism, money has become the essence of man's life and work ... Jews are the embodiment of capitalism in action and the creators of all its evil consequences for humanity" (Perry, 2002: 156). However, Jews have also been labeled as the driving force behind communism as well. During the Russian Civil War, the propaganda of the anticommunist "White" forces often tied Judaism and Bolshevism together and claimed that Jews were behind the communist movement in order to serve their own interests. This myth grew in large part due to the circulation of The Protocols of the Elders of Zion (Pipes, 1997: 93). Since that time, the notion of "Jewish Bolshevism" was perpetuated as a conspiracy theory, and has at times been viewed as a threat by nationalist factions in numerous countries.

While there is no single overriding myth with regard to economic anti-Semitism, there are a number of stereotypes that have endured and provided the basis for various canards. The perception among many that Jews are stingy, greedy, dishonest, and unproductive has carried on since the medieval era. These characteristics have defined the numerous conspiracy theories that tend to scapegoat Jews for the hardships of gentiles. Jews have been blamed for the negative aspects of both capitalism and communism, which has allowed economic anti-Semitism to fester among many different ideologies and endure for centuries.

\section{Racial Anti-Semitism}

Racial anti-Semitism is distinct, in that it denotes prejudice or hatred of Jews as a religious or ethnic group, rather than Judaism as a religion. Therefore, racial antiSemitism purports that Jewish blood, and not simply Jewish beliefs, are inferior. Racial 
anti-Semitism is most commonly claimed to have originated in medieval Spain. During the Spanish Inquisition, many questioned the sincerity of those Jews who converted to Christianity (conversos). Consequently, an ideology of "cleanliness of blood" arose within the Spanish nobility, which influenced a series of statutes and legal decrees aimed at persecuting the conversos. Thus, the conversos could be persecuted based on their Jewish ancestry and ethnicity, rather than simply their beliefs (Kamen, 1998: 19-26) (Murphy, 2012: 69-77).

Racial anti-Semitism increased in prominence in the nineteenth century due to a combination of increased popularity of nationalism and certain pseudo-scientific theories such as eugenics. While neither ideology is inherently anti-Semitic, leaders adhering to these ideologies often embraced anti-Semitic racism as well. Francis Galton, often cited as the founder of modern eugenics, claimed that Jews were "specialized for a parasitical existence" (Pearson, 1924: 209). Such statements conveyed the notion that Jewish ethnicity predisposed one to particular behaviors and lifestyle. Galton was inspired by Charles Darwin's The Origin of the Species and developed eugenics as a means to improve human heredity. As the eugenics movement grew, various policies were proposed to coerce societies into producing what could be considered more "fit" children. Such policies first targeted the mentally and physically handicapped, but later came to include numerous other groups including Jews (Levy, 2005: 212).

Around the same time, romantic nationalism began to spread across Europe that relied upon the idea that a historic ethnic culture could lead a nation to a romantic ideal. The rise of such populist, völkisch movements were inspired not only by international events, such as the American and French revolutions, but also by the literature and 
philosophy of such figures as Johann Gottfried von Herder, the Brothers Grimm, Georg Wilhelm Friedrich Hegel, and Johann Gottlieb Fichte (Wilson, 1973: 828-830). Although these movements were not universally anti-Semitic, romantic nationalism often placed an emphasis on exclusivity, purity, and the superiority of one particular ethnic group over all others. Consequently, Jews were often viewed as an impediment or obstacle to a nation achieving its romantic ideal. For example, Richard Wagner claimed to identify "Jewishness" in musical style, due to what he asserted was Jews' unwillingness to assimilate into German culture and truly comprehend the nation's music and language (Wagner, 1869). Wagner did not claim that these perceived deficiencies were necessarily the result of Jewish beliefs, but rather an inherent quality of ethnic Jews. In these ways, romantic nationalism often allowed for Jews to not only be viewed as a scapegoat, but also an impediment to a nation and ethnic culture's ambitions to achieve an ideal.

The combination of pseudo-scientific eugenics theory and romantic nationalism could in some ways be viewed as parallel with regard to their emphases on ethnic superiority and exclusivity. Although not necessarily based on anti-Semitic grounds, these ideologies became important contributors to the development of racial antiSemitism. Both ideologies allowed for certain out-groups to be viewed as inferior, which Jews were often considered. However, with the rise of eugenics and romantic nationalism, Jewish inferiority could now not only be attributed to a particular belief system, but also a genetic predisposition. This is the primary way in which racial antiSemitism differs from other forms. 


\section{Political Anti-Semitism}

Political anti-Semitism shares many of the same traits associated with economic anti-Semitism, except the emphasis is placed on a different sector of society. Political anti-Semitism most often relies on conspiracy theories based on the belief that Jews seek national or world power. Because of such perceived Jewish ambitions, political antiSemites often view Jews as an enemy and tend to place blame on Jews for their own political defeats. Such sentiment can occasionally translate into official anti-Semitic positions in political party platforms (Grobman, 1983: 100).

Holocaust denial has indeed become one of the more prominent manifestations of political anti-Semitism. Although anti-Semitism and anti-Zionism are different phenomena, Holocaust denial has often served as a link between the two. As is the case with the other forms of anti-Semitism, The Protocols of the Elders of Zion is an important text in this regard. Since its publication, many have interpreted the text as evidence of a Zionist conspiracy for world domination. After World War II, some claimed that the Holocaust was indeed part of such a conspiracy, in that the genocide was either a hoax or the numbers were grossly inflated, in order to achieve Zionist objectives (Martin, 2015: 138). These claims asserted that Zionists either imagined, exaggerated, or were even complicit in the Holocaust in order to gain greater leverage in negotiations with Western powers for the establishment of a Jewish state (Herf, 2013) (Wistrich, 2012). Some contemporary radical political figures contend that Zionists/Jews continue to yield illegitimate influence in Western governments, in part due to what they consider the leverage gained through mythical or exaggerated understandings of the Holocaust and its aftermath (Liang, 2013: 158). 
These sorts of suspicions and fears have become a central element in the ideologies and doctrines of numerous anti-Semitic political parties and movements. Notably, anti-Semitism is not exclusive to any particular end of the political spectrum. Rather, Jewish motifs are often used to represent an enemy from many different directions (Gross, 2006). This phenomenon is vividly demonstrated throughout Russian history, where Jews faced persecution from both communist and anti-communist factions (Korey, 1995). One crucial factor in developing group unity in any political movement is defining an enemy whom to mobilize against. And given their distinct history, culture, and religious beliefs, Jews have consequently been perceived in many cases as outsiders, even in countries in which they may have resided for generations. Propaganda plays an important role in identifying, isolating, and excluding these "outsider" groups. By defining the enemy in this manner, it becomes easier for parties or movements to air grievances against the particular enemy or "out-group" and scapegoat them for hardships and setbacks (Arendt, 1951: 43-47). The sources of grievances and scapegoating may differ between regions and parties; however, the tactics of defining Jews as an enemy as a means to creating group unity is a common theme in political anti-Semitism.

\section{New Anti-Semitism}

One of the more controversial debates among scholars is whether or not antiSemitism tends to manifest itself as opposition to Zionism and the State of Israel. Those who argue that there is indeed a "new anti-Semitism," originating soon after the establishment of Israel, contend that this new form combines elements of anti-Zionism, anti-Globalization, anti-Americanism, and the application of double standards in attempts to demonize and delegitimize the State of Israel and Jews' right of self-determination. 
Furthermore, those arguing for this conceptualization suggest that "new anti-Semitism" is often linked either explicitly or implicitly with other attacks on Jewish interests or symbols. Critics of the concept of "new anti-Semitism" counter by arguing that this "new" conceptualization is too broad in scope, and consequently conflates anti-Zionism and legitimate critiques of Israeli policy with anti-Semitism - concepts that should be viewed as distinct. These critics also claim that the conception of "new anti-Semitism" tends to trivialize the meaning of anti-Semitism, and in some cases exploits the term in order to silence political debate.

Those who argue that there is a distinct, new anti-Semitism contend that the establishment of Israel changed the nature of anti-Semitism, in that it provided a new symbol of Judaism upon which hatred and assaults could be based. Irwin Cotler contends that whereas classical or traditional anti-Semitism is defined by "discrimination against, denial of or assault upon the rights of Jews to live as equal members of whatever host society they inhabit," new anti-Semitism is marked by "discrimination against the right of the Jewish people to live as an equal member of the family of nations - the denial of and assault upon the Jewish people's right even to live - with Israel as the 'collective Jew among the nations"' (Cotler, 2009). So while Cotler's definition of new anti-Semitism carries themes similar to classical anti-Semitism, whereas classical anti-Semitism attempted to delegitimize the existence of Jewish individuals and beliefs, new antiSemitism attempts to delegitimize the existence of a Jewish state.

Some scholars attribute the rise of a new anti-Semitism to the increasingly globalized nature of world politics and economics. Whereas the anti-Semitism prior to World War II primarily rose in an environment defined by entrenched nationalism, the 
anti-Semitism of today is defined by an increasingly globalized environment. Robert Wistrich has argued that this new anti-Semitism has become especially prevalent among the groups who have benefitted the least through globalization by writing, "Israel is only one piece on this chessboard, but it has assumed such inflated importance because it serves a classic anti-Semitic function of being an 'opium for the masses"' (Gerstenfeld, 2004). Because of this situation asserts Rabbi Jonathan Sacks, the Chief Rabbi of the United Kingdom, a new, diverse anti-Semitic coalition has been formed that "unites radical Islamists with human-rights NGOs — the right wing and the left wing — against a common enemy, the State of Israel" (Sacks, 2011). Those who argue the existence of a new anti-Semitism often cite this wide, diverse coalition as characteristic of the phenomenon of new anti-Semitism.

The European Monitoring Centre on Racism and Xenophobia (EUMC) (replaced in 2007 by the Fundamental Rights Agency) began pushing Council of Europe member states to include anti-Semitism in anti-racist criminal law in 2004, and notably the EUMC's definition of anti-Semitism included anti-Israel sentiment. The EUMC released a report with a section entitled "Examples of the ways in which anti-Semitism manifests itself with regard to the state of Israel." This section included five ways, including: 1) Denying the Jewish people the right to self-determination, e.g. by claiming that the existence of a state of Israel is a racist endeavor; 2) Applying double standards by requiring of Israel a behavior not expected or demanded of any other democratic nation; 3) Using the symbols and images associated with classic anti-Semitism (e.g. claims of Jews killing Jesus or blood libel) to characterize Israel or Israelis; 4) Drawing comparisons of contemporary Israeli policy to that of the Nazis; 5) Holding Jews 
collectively responsible for actions of the State of Israel (European Monitoring Centre on Racism and Xenophobia, 2006). These parts of the EUMC definition align closely with what many consider new anti-Semitism.

Other scholars disagree with assertions that there is a "new anti-Semitism," and instead argue that any contemporary incidence of anti-Semitism can be attributed to classical anti-Semitism. Yehuda Bauer contends that anti-Semitism has not changed over time, only its triggers. He argues, "Western anti-Semitism is not new. This concept of 'New Antisemitism' is, I think, quite false. It is the old pre-Hitler anti-Semitism that utilizes occasions to come to the fore when something triggers [it]. Now it is the Israel situation.” Bauer continues by stating that even if a peaceful Mideast solution were reached, "the anti-Semitism would not disappear, it would still be there and there would then be another trigger. It's a very slow process to deal with, latent anti-Semitism ... Antisemitism is a cultural phenomenon and cultural phenomena take a long time to change" (Fleischer, 2007). Therefore, while the triggers of anti-Semitism may change over time, Bauer argues that the general themes and implications tend to remain constant. Similarly, Brian Klug argues that there is no single, unified phenomenon that one could call "new anti-Semitism." Klug contends that the concept of "new anti-Semitism" has instead been an attempt to equate anti-Semitism with anti-Zionism, which he argues is illogical. Klug writes that "to argue that hostility to Israel and hostility to Jews are one and the same thing is to conflate the Jewish state with the Jewish people. In fact, Israel is one thing, Jewry another. Accordingly, anti-Zionism in one thing, anti-Semitism another" (Klug, 2004). Klug goes on to contend that the two can in some ways be connected, but, once again, this does not mean that they are one in the same. In fact, Klug argues that the 
vague nature of "new anti-Semitism" actually dilutes the true meaning of anti-Semitism. He writes, "when anti-Semitism is everywhere, it is nowhere. And when every antiZionist is an anti-Semite, we no longer know how to recognize the real thing--the concept of anti-Semitism loses its significance" (Klug, 2004).

The debate over "new anti-Semitism" is important to recognizing where Israel fits into the definition of anti-Semitism. Each of the authors in this section acknowledge that there are indeed legitimate critiques of Israeli policies that are not inherently anti-Semitic. However, the existence of Israel has in many ways changed the dynamics of world politics and grievances have arisen due to the actions of the state and its allies. And as Israel is considered a Jewish state, there is consequently a fine line between critiques of Israel and discrimination against Jews - a line that must nonetheless be acknowledged. The emerging debate over "new anti-Semitism" remains controversial and the literature on the subject is rather underdeveloped. The role that Israel plays in sparking outbreaks of anti-Semitism is nonetheless an important issue in analyzing the topic of anti-Semitism in the twenty-first century.

\section{An Operational Definition of Anti-Semitism}

In examining the term, it becomes clear that the concept of anti-Semitism has evolved throughout history and includes various forms of prejudice and discrimination. Religious anti-Semitism has existed for millennia and singles out Jews as sinful, dishonest, weak, and subversive - depending on the accusers' own religious teachings and traditions. Economic anti-Semitism tends to invoke conspiracy theories that scapegoat Jews as the cause of gentile hardships and depicts Jews as greedy and unproductive. Racial anti-Semitism purports that Jewish blood, and not simply Jewish beliefs, are 
inferior and that their mere presence can impede the societies in which they live of achieving national ambitions. Meanwhile, political anti-Semitism proposes conspiracy theories that Jews have undue influence over global affairs and that their distinct history, culture, and religious beliefs makes them an enemy "out-group" against which political movements should mobilize. One must comprehend these four strains of anti-Semitism religious, economic, racial, and political - to fully define and conceptualize the meaning of anti-Semitism.

As it is outside the scope of this project to resolve the debate regarding "new antiSemitism," issues of anti-Semitism relating to the State of Israel will be considered forms of political anti-Semitism for this analysis. Indeed not all critiques of Israeli policy are inherently or even connected to anti-Semitic beliefs; however, when criticism of Israel is formulated as an indictment of all Jews - such rhetoric may be considered anti-Semitic. This is an important distinction to make in defining what constitutes anti-Semitism.

The operational definition of anti-Semitism for use throughout this analysis is as follows: hostile attitudes or attacks targeting Jewish people, symbols, or interests based on religious, economic, racial, or political grounds. This definition refers to "hostile attitudes or attacks (on persons, property, or symbols)" because these are important indicators, which are most typically used in measuring levels of anti-Semitism. The definition refers to "targeting Jewish people, symbols, or interests" because these are easily identifiable, tangible things against which hateful, discriminatory attitudes or acts are most often aimed. And finally, this definition notes that these attitudes or attacks are based on religious, economic, racial, or political grounds in order to emphasize the different strains or manifestations of anti-Semitism. This definition best encompasses the 
ways in which anti-Semitism is measured and tends to manifest. The following sections will examine the historical development of anti-Semitism in the cases of both Germany and Poland. The structure of the case studies will examine each strain of anti-Semitism (religious, economic, racial, and political) individually in order to best demonstrate the evolution and manifestations of the problem in these two cases over time.

\section{The Problem of Anti-Semitism in Germany}

\section{b. Religious Anti-Semitism in Germany}

The earliest known Jewish settlements in the land that forms modern Germany were most likely established around the fourth century - coinciding with Christianity becoming the state religion of the Roman Empire (Lieu, 2013: 117). This time period was marked by increased hostility toward Jews with such hostility often based on religious grounds. Once Christianity became the state religion of Rome, Jews became more frequently targeted for attack and experienced greater restrictions on their political rights. Many of these measures and other attacks on Jewish people, symbols, and interests have been attributed to hostility in early Christian literature related to claims of collective Jewish responsibility in Jesus's execution (Schweitzer, 2002: 26). These claims were based on passages in the New Testament, in particular Matthew 27:24-25, in which Jews shout that Jesus's blood is on their and their children's hands. In addition, the first Christian Emperor of Rome, Constantine I, instituted a number of policies regulating Jewish religious services, restricting congregations, outlawing Christian conversion to Judaism, and intermarriage between Christians and unconverted Jews (Cohn-Sherbok, 2006: 34-35). Due to these factors, one may claim that the religious strain of anti- 
Semitism has existed on German land for as long as the Jewish communities that settled there.

Over the following centuries, Jewish communities continued to expand on German lands, although the civic and social status of Jews varied across the subsequently established Germanic kingdoms. The situation worsened significantly, however, around the time of the First Crusade in 1096. In fact, German Jews were one of the first groups persecuted as part of the Crusades. Jewish communities tended to be in much closer proximity to Catholic communities in Central Europe than the more distant Muslims. And since Jews continued to be blamed by many for the death of Christ, Jews were often viewed as just as much an enemy as Muslims. The Frankish knight Godfrey of Bouillon, one of the leaders of the German Crusade, demonstrated the religious anti-Semitism of the time by vowing "to go on this journey only after avenging the blood of the crucified one by shedding Jewish blood and completely eradicating any trace of those bearing the name 'Jew,' thus assuaging his own burning wrath" (Eidelberg, 1977: 25). This type of sentiment led to massacres of Jews in the Rhineland with an estimated 12,000 executed in the summer of 1096 alone. The entire Jewish communities in Cologne, Worms, Trier, and Mainz were eradicated during this time (Riley-Smith, 1991). In other areas where many of the native Jews survived, these Jews were nonetheless frequently the targets of extortion by crusaders seeking to supply themselves on their mission (Golb, 1998). Other Jews, such as those in the city of Regensburg, were subjected to involuntary mass baptisms in the Danube (Baron, 1957). The Crusades led to one of the widest scale and aggressive persecutions of German Jews prior to the Holocaust. However, whereas many future persecutions were often the result of a culmination of strains of anti-Semitism, the 
persecution during the Crusades was defined primarily by an intensely religious antiSemitism.

Religious anti-Semitism continued to be perpetuated throughout the Middle Ages, often through imagery depicting Jews in derogatory or dehumanizing ways. These sorts of derogatory depictions of Jews were often part of imagery known as Judensau (Jews' sow) that portrayed Jews in obscene positions with unclean animals and often added elements of Jews representing the devil. Judensau imagery began to appear in the thirteenth century and even appeared on church or cathedral walls in the centuries following (Schreckenburg, 1996: 331-337). These sorts of depictions of Jews worked to reinforce the portrayal of the Jew as a Christ killer and became a clear manifestation of religious anti-Semitism. Some of the most notable examples of Judensau appear on churches in the city of Wittenburg, including on the façade of the Stadtkirche where Martin Luther preached (Wolffsohn, 1993: 194). Judensau remained popular in many of the German territories until the nineteenth century and became one of the most visible manifestations of religious anti-Semitism that reinforced and perpetuated a number of Christian suspicions and myths regarding Jews and their religious practices.

A frequent lack of Christian understanding and tolerance for Jews and their religious practices also manifested itself in numerous accusations leveled against Jews for events that, at the time, many believed could not be otherwise explained. Jews often became the scapegoats for such things as outbreaks of disease and cases of missing and deceased children. Throughout the Middle Ages, populations often lacked basic understanding of how diseases spread, and this tended to lead survivors to search for reasons why crowded cities could experience massive outbreaks of illness, such as during 
the bubonic plague. A common scapegoat for these outbreaks of disease were citydwelling Jews, who often lived in segregated ghettos, and became accused of poisoning the wells. The widest known persecutions due to such accusations were during the bubonic plague, including in the German city of Erfurt where estimates suggest anywhere from a few hundred to three thousand Jews were executed based on well poisoning accusations (Laqueur, 2006: 62). Blood libel was also commonly invoked as an explanation for children who went missing and were subsequently found dead (Aring, 1998: 837-838). There were about 150 recorded cases of blood libel, with thousands of other rumors, around Europe throughout the Middle Ages that led to the revenge killings and persecutions of Jews for centuries (Laqueur, 2006: 56).

Through the Age of Enlightenment, many Jews continued to lack certain civil and social rights; however, the degree of violent attacks and persecutions was not on par with the levels experienced during the Middle Ages. In fact, a number of Jews, such as Moses Mendelsohn, were able to increase their social standing and civic enfranchisement during the Enlightenment by influencing German thought and scholarship. The Jewish Reform movement also served to better integrate many Jews into German society. During the nineteenth century, Jewish life often vacillated between periods of freedom and oppression with Jews receiving ostensible legal equality following the revolutions of 1848 (Johnson, 1988: 395). From the late nineteenth to early twentieth century, religious anti-Semitism had largely given way to other strains of anti-Semitism that began to rise around this time.

The rise of the Nazis during the 1920's and 1930's caused a revival of the rhetoric and many of the themes associated with religious anti-Semitism that had been so 
influential in Jewish persecutions centuries earlier. Many scholars argue that the strain of religious anti-Semitism tracing back centuries played a pivotal role in conditioning many Germans to accept Jewish persecution. For this reason, the Nazis often invoked the writings of Martin Luther to expand the appeal of their policies and justify their approach to certain audiences. The most prominent of Luther's writings distributed by the Nazis was his treatise entitled On the Jews and Their Lies, which was known to have been distributed at the Nuremburg rallies and passages published in the Nazi newspaper Der Stürmer (Ellis, 2004). Passages such as these reinforced the Nazi argument for the extermination of Jews and added a religious aspect to the other forms of anti-Semitism exhibited by the regime.

Although Nazism itself was not an inherently religious movement, elements of German society did indeed attempt to more closely align Christianity with Nazi beliefs. The most prominent Nazi-aligned religious movement was the Deutsche Christen (German Christians), who can most concisely be described as a group of nationalist, Nazi Protestants. The German Christians actively promoted many of Luther's anti-Semitic writings and attempted to transform Christian theology to also reflect Nazi ideals. Consequently, this particular religious faction sought to de-emphasize the Old Testament in Protestantism and remove portions of the Bible that were deemed to be "too Jewish" (Bergen 1996). The Nazi Party encouraged these sorts of belief through what was termed "positive Christianity," which blended ideas of racial purity and Nazi ideology with elements of Christian theology. Hitler even claimed in a March 23, 1933 speech to the Reichstag that Christianity was the "foundation" of German values (U.S. Holocaust Museum, 2014). Many historians, however, such as Ian Kershaw and Laurence Rees, 
argue that Hitler did not necessarily have much regard for faith and religion, but rather used religion pragmatically due to its historical importance and influence in German society (Rees, 2012: 135). So while Nazism itself was not necessarily based in theology, in practice the Nazi Party was opportunistic in using religion to strengthen support of its anti-Semitic policies.

Following World War II and the Holocaust, the strain of religious anti-Semitism became less prominent within Germany, although the symbolism and rhetoric of modern anti-Semitism often reflects some similar themes. Religion in general has declined in Germany, in part due to the imposition of communism in the eastern portion of the country during the Cold War and the increasing popularity of secularism in parts of the West. In fact, a 2006 survey showed that $51 \%$ of German youth between the ages of 12 and 24 were either agnostic or atheist (Gensicke, 2006). Such data suggests that religious anti-Semitism likely does not have the same levels of resonance as it once did, for example, during the Middle Ages or the Reformation. Christian churches have also become more likely to actively denounce anti-Semitic behavior with events such as the Second Vatican Council aiming, in part, to repair relations between Christians and Jews and repudiate particular sources of religious anti-Semitism, such as allegations of deicide. Many in the Lutheran Church have also come to renounce the more anti-Semitic writings of the church's founder. Nonetheless, certain rhetoric such as the common anti-Semitic slur "Judenschwein" (Jewish pig) originate from the religious strain of anti-Semitism that has existed for centuries. Synagogues also remain one of the prime targets of anti-Semitic attacks with the German government reporting 82 attacks on synagogues between 2008 and 2012 (Wienthal, 2013). So while there has been some movement on improving 
Christian-Jewish relations in recent years, there are indeed elements of modern antiSemitism in Germany that mirror the sort of religiously based attacks that have taken place for centuries.

At the same time, Germany has experienced a surge in its Muslim population since the end of World War II and this has made Islamic-Jewish relations an increasingly important dynamic in the study of anti-Semitism within the country. By 2006, Muslims were estimated to make up approximately $5 \%$ of the total German population. Germany's Muslim population is also markedly more religious than the non-Muslim population with $73 \%$ of German Muslims claiming to be either "fairly religious" or "very religious" compared to less than 30\% for non-Muslims (Gesemann, 2006: 8-9). There is some evidence of Islamic religious anti-Semitism in Germany, and particularly with regard to the belief that Jews are to be a subject of ridicule, with a 2012 survey of Turkish-German Muslims showing that $18 \%$ believed Jews to be inferior human beings (Die Welt, 2012). However, while there does indeed appear to be some traces of religious anti-Semitism among Germany's Muslim population, the other strains tend to be more prominent in the contemporary environment.

\section{c. Economic Anti-Semitism in Germany}

In Germany, economic anti-Semitism was in part borne out of religious antiSemitism, but has nonetheless become its own distinct form over time. Following the First Crusade, Jews became frequently subjected to various legal restrictions, many of which centered on the types of occupations that they could fill. Occupations such as moneylending and tax collecting tended to be viewed as socially inferior, and in fact moneylending with interest was considered sinful by Catholic doctrine throughout the 
Middle Ages. Whether by choice or necessity, these occupations were often filled by Jews and consequently led to a number of stereotypes and adversarial relationships that have come to characterize the essence of economic anti-Semitism.

As many Jews entered financial occupations, the relationships between Christians and Jews often became more adversarial with Christian debtors viewing Jewish creditors as greedy usurers (Dimont, 1962: 268). A number of rulers throughout the Holy Roman Empire relied on Jewish financiers, commonly referred to as Court Jews, to negotiate financial agreements and ensure that their territories had a requisite number of resources. Given their influence and social connections in such positions, Court Jews would frequently make a number of enemies, enemies who would occasionally target the Court Jews following the death of the ruler for whom they had worked (Tegel, 2011). This phenomenon was reflected in an iconic piece of German literature and film known by the name Jud Süß (Süss the Jew). Many adaptations of Jud Süß were not intended to have anti-Semitic undertones; however, the story of $J u d$ Sü $\beta$ came to reinforce a number of economic stereotypes regarding Jews, and indeed became an influential part of Nazi propaganda through film. Jud Süß became a figure representing the stigma of Jews as usurious, manipulative, and fraudulent financiers - thus serving as a prime representation of economic anti-Semitism that has carried on for centuries.

During the nineteenth century, Jews in a number of German territories such as Prussia, Hesse, Württemberg, and Hanover had been emancipated as citizens, were granted new civil rights, and were able to elevate their social standing. The establishment of the German Empire in 1871 also removed many of the remaining legal barriers that Jews had faced. This allowed a number of German Jews to become more influential in 
fields previously not available to them, such as literature, politics, and law. However, while a number of legal barriers were indeed lifted, the strain of economic anti-Semitism remained (Lazare, 1903). The perceptions of Jews as powerful and rich were often exacerbated via literature and theater at the time with figures such as the Rothschild family often depicted, as Howard Sachar describes, "Jewish cash bags" or "Jews behind the throne" (Sachar, 2005). While many of these works were intended as satire, they were in many cases consistent with the sort of stereotypes and perceptions associated with economic anti-Semitism that gained momentum in the decades that followed.

During the beginning of the twentieth century, Jews became increasingly integrated within German society, so much so that a higher percentage of German Jews fought in World War I than any other religious or ethnic group in Germany (Rigg, 2002: 72). In the Weimar Republic, many Jews began to play a major role in politics and diplomacy and were able to achieve greater social status than was previously possible. In fact, Hugo Preuß, the Weimar Republic's first Interior Minister, authored the initial draft of the Weimar Constitution (Stirk, 2002). Nonetheless, anti-Semitic beliefs continued to manifest. In the early 1920's, there were sporadic outbreaks of anti-Semitism with some claiming that Jews betrayed Germany and were responsible for defeat in World War I - a myth known as the Dolchstoßlegende (Stab-in-the-back myth). The Protocols of the Elders of Zion were also first published in German in 1920 leading to wider dissemination of conspiracy theories targeting Jews. The anti-Communist, and increasingly anti-Semitic, Freikorps paramilitary organization also became more active during this period. Although there were clear examples of anti-Semitism throughout the 1920's that often scapegoated Jews and alleged various conspiracy theories, the 
consequent violence tended to be sporadic rather than systematic. However, once economic circumstances changed in 1929 with the onset of the Great Depression, antipathy toward Jews increased rapidly and anti-Semitism became more systematic than at any other time in history.

The Nazi regime embodied each major strain of anti-Semitism, but one must note that the Nazi rise to power occurred in an environment of economic depression. The late 1920 's and 1930's was certainly a time of economic anxiety and despair within Germany due to both economic decline and rapid monetary inflation. Adolf Hitler directly pinned blame for such circumstances on German Jews and what he argued were Jewish attempts to "Bolshevize" Germany. The following passage from Mein Kampf is a prime example of such sentiments:

The Jewish train of thought in all this is clear. The Bolshevization of Germanythat is, the extermination of the national folkish Jewish intelligentsia to make possible the sweating of the German working class under the yoke of Jewish world finance - is conceived only as a preliminary to the further extension of this Jewish tendency of world conquest.... If our people and our state become the victim of these blood-thirsty and avaricious Jewish tyrants of nations, the whole earth will sink into the snares of this octopus. (Downs, 2004: 361)

These sorts of conspiracy theories gained traction during the Nazi regime and played a key role in the justification for the passage of the Nuremburg Laws and the boycotting of Jewish shops and services. In fact, the Nazi-led boycotts of Jewish businesses was one of the first measures taken by Hitler after his appointment as Chancellor - taking office on January 30, 1933 and beginning the boycott on April 1, 1933 (Lang, 2009: 132). As state efforts against Jewish business progressed, harassment, vandalism, arrests, and pillaging became increasingly common with November 9-10, 1938 - known as Kristallnachtbeing the most vivid example. Jews were also increasingly segregated from Aryan 
Germans and were eventually banned from public schools, universities, cinemas, theatres, and other recreational facilities. Such restrictions had devastating impacts on Jewish economic and professional life. Of the 50,000 businesses in Berlin in 1939, all had Aryan owners by 1945 (Kreutzmüller, 2012). Economic anti-Semitism was indeed visible from the earliest days of the Nazi regime and was one of the primary means of separating Jews from the rest of the German population.

Given that Germany's Jewish population had been devastated and greatly reduced due to the Holocaust, the effects of economic anti-Semitism were less pronounced in the post-war period, but did nonetheless exist to varying extents in the German Democratic Republic (GDR) and the Federal Republic of Germany (FRG). A primary economic motivation that fueled resentment against Germany's remaining Jewish community was the notion of restitution and reparations for those Jews who had their property confiscated following rise of the Nazi government in 1933. Legislation drafted by the Allied countries obligated German property owners to return property confiscated from Jews after 1933 to the original owners or their errors. Such laws were criticized by many Germans and led to bitter fights between German and Jewish property owners. The press, particularly in the FRG, often criticized such policies and portrayed them as unjust (Bergman and Erb, 1997: 13). Also in the FRG, Germans who were compelled to return property formed various organizations, which often focused on the most controversial aspects of the restitution procedures and perpetuated negative economic stereotypes of Jews. Many of the publications of such organizations selected particular cases in order to portray the surviving Jews as corrupt and in pursuit of personal enrichment. While these efforts were primarily intended to pressure the federal government to revise, or 
completely end, the restitution policies, they also served as a prominent manifestation of anti-Semitism in the post-WWII period (ibid.).

It is important to note that while there is insufficient data to effectively compare anti-Semitic attitudes in the FRG and GDR from 1945-1990, the Jewish populations in both states varied significantly. According to the 1933 census, pre-WWII Germany had an estimated Jewish population of 500,000. By 1945, the FRG had approximately 37,000 Jews, while the GDR only had a few hundred. These numbers decreased even further in the decades following the war, as many Jews emigrated to Israel, the United States, Canada, the United Kingdom, and other locations (U.S. Holocaust Museum, 2015). So while the FRG had a greatly decreased Jewish population, the GDR had a virtual absence of Jews. As there were no extensive surveys conducted on anti-Semitic attitudes in the former GDR, it is difficult to compare the attitudes between the separate German states before 1990.

Surveys conducted in the FRG also indicate that the economic discrimination and boycotts of Jewish businesses had a lingering effect in the postwar period. Negative stereotypes of Jews remained relatively consistent during the period of a divided Germany with 23\% of West Germans agreeing in 1960/61 that "greedy" was a "Jewish characteristic" and 20\% still holding such a view in 1986/87 (Bergmann and Erb, 1997: 111). Such attitudes were also reflected in attitudes toward Jewish owned businesses. In $1949,25 \%$ of West Germans rejected the idea of shopping in Jewish owned stores even if the prices were lower. Notably, this sort of economic anti-Semitism was more prevalent among the well-educated of whom $30 \%$ responded that they would avoid Jewish stores compared to $22 \%$ of those with only an elementary education. Surveys taken in 1961 and 
1965 also demonstrated that $14 \%$ of West Germans had reservations about being treated by a Jewish doctor. West German women were more likely to have such reservations than men $-18 \%$ compared to $10 \%$. These gender-specific differences are most likely due to Nazi stereotypes that depicted Jewish men as sexually aggressive and condemned any contact between Jews and other Germans (Bergmann and Erb, 1997: 150-151). So while the Nazi regime may have ended in 1945, the legacy of economic discrimination and stereotypes remained among about a quarter of the West German population in the decades following WWII.

Shortly after German reunification, it became possible to compare data on antiSemitism in the states that composed the former GDR and the FRG. Notably, Eastern Germans tended to feel less threatened by Jewish influence than their counterparts in the areas of Western Germany. In 1994, only 8\% of East Germans agreed with the statement that "Jews have too much influence in our society," whereas $24 \%$ of West Germans agreed with such a statement (Weil, 1997: 114). Of course, the responses to this statement may be influenced by the higher Jewish population in West Germany and the relative homogeneity of the former East.

However, while such anti-Semitic attitudes may be less prevalent in the former East, the fervency of those with such beliefs and the propensity for violence tends to be higher on average in the Eastern states. In response to a question as to whether or not a respondent believes "anti-Semitic groups have a big following" $36 \%$ of former East Germans answered yes, whereas only $26 \%$ of West Germans responded similarly (Weil, 1997: 119). So while anti-Semitic attitudes may have been higher in the Western states, those with anti-Semitic and xenophobic beliefs in the Eastern states tended to be more 
likely to join organizations and act on such beliefs. Between 1991 and 1995, about one third of violent hate crimes in Germany occurred in the former East, which, relative to population, means that such crimes are on average more likely to occur in the Eastern states (Bergmann, 1997: 34). So while survey data indicates that levels of economic antiSemitism were indeed lower in the former GDR, those with such beliefs were more likely to act out violently.

Fueled by conspiracy theories and scapegoating, economic anti-Semitism has long remained a problem in German society. In many ways, economic anti-Semitism has its roots in religious anti-Semitism and indeed these two strains have often paralleled one another throughout history. Many of the negative Christian depictions of Jews as untrustworthy and conniving for their alleged role as conspirators in the death of Christ parallel the images of Jews with regard to economic problems. In many different periods of German history, policies were implemented to restrict economic opportunities for Jews and constrain them to certain professions. Economic anti-Semitism has remained a consistent and prevalent strain of anti-Semitism for centuries in Germany, and therefore further evaluation of the state responses to this problem, or lack thereof, is worthy of further evaluation.

\section{d. Racial Anti-Semitism in Germany}

Racial anti-Semitism differs in that hostility is instead based on racial/ethnic grounds. The rise of racial anti-Semitism in Germany is most commonly attributed to two main factors: pseudo-sciences, such as eugenics, and ethnic nationalism (Ehrenreich, 2007: 135). Whereas religious anti-Semitism commonly pinned blame on Jews for deicide and economic anti-Semitism pinned blame on Jews for various economic 
problems, racial anti-Semitism tended to pin blame on Jews for preventing the majority race from reaching a national ideal. In Germany, racial anti-Semitism largely arose from the romantic nationalism of the nineteenth century and culminated during the Nazi era. Given the emphasis on genetics and purity of blood that racial anti-Semitism often emphasizes, Jews are commonly viewed by racial anti-Semites to be essentially incurable. This rationale is often cited as a primary motivation for the mass extermination of the Jewish race, and therefore arguably the most dangerous and potentially violent strain of anti-Semitism (ibid: 175).

While the origins of racial anti-Semitism can be found in the history of the Spanish inquisition, this strain of anti-Semitism did not become a significant factor in Germany until the rise of romantic nationalism in the nineteenth century. An important aspect of the romantic nationalism that began to arise in the early nineteenth century was the emergence of völkisch movements, which were often ethno-nationalist in nature. The German word Volk corresponds to the English word people, but, as used in this historical context, Volk tends to carry certain populist, ethnic connotations. As historian James Webb writes, the term Volk has at times carried 'overtones of 'nation,' 'race,' and 'tribe"” articulated in an emotional tone (Webb, 1976: 277) (Pietikäinen, 2000: 524). These emotional elements often focused on the relationship between ethnicity and territory with certain messages amplified through German folklore, local history, and anti-urban populism. Many of the völkisch movements, and romantic nationalism in general, emphasized ideas about nature and a certain natural order that created ideal images of society often based on ethnic homogeneity and superiority, and consequently subjugated the position and value of those perceived as outsiders. 
Complementing this rise in ethno-nationalist, völkisch movements was the emergence of racialized pseudo-sciences, such as eugenics, that focused on measures that some believed would improve the genetic quality of humanity. While eugenics began in England with the writings of Francis Galton, similar beliefs spread across Europe by other theorists such as Arthur de Gobineau in France who argued that the mixing of races caused a degeneration of humanity. He contended that whereas European civilization had once flowed from Greece to Rome, contemporary civilization was based in Germany, and that the German race was the most superior. He believed that contemporary German society corresponded to the ancient Indo-European culture, and thus began using the term "Aryan" as synonymous with "German" (Bartulin, 2013: 23). However, de Gobineau asserted that just as past civilizations fell, German civilization would also fall once the races became "polluted," as he believed had already been the case in France.

While racial anti-Semitism had been engrained within particular movements and pseudo-scientific theories as far back as the early nineteenth century, this particular strain of anti-Semitism did not become a wide-scale public policy initiative in Germany until the rise of the Nazi party in the 1930's. The belief that Jews as a race, and not merely a religion, were inherently inclined to subvert and poison society has arguably been the most important rationale for the oppression and genocide of Jews since the Middle Ages. The concept of "cleanliness of blood" that first arose during the Spanish Inquisition, and later became an important theme in Nazi propaganda, essentially did not allow for Jews to be "cured" of their Jewishness through means such as conversion and thus they were unable to function and participate fully as members of society. The Nazi movement built upon the racialist theories and ethnic nationalism of the nineteenth century and used such 
beliefs to develop and implement doctrines seeking to "purify" the blood of those in German society by diminishing the influence of, and eventually eliminate, the populations of those deemed undesirable and racially inferior.

One of the earliest, and most prominent, manifestations of Nazi racial antiSemitism was the passage of the Nuremburg Laws that, among other things, forbade marriage or extramarital intercourse between Germans and Jews, forbade German females under 45 years of age from working in Jewish households, and established that only those with German or related blood were eligible to be citizens of the Reich. The basis for such laws was based on the same ideology of Arthur de Gobineau, who argued that the mixing of races was a direct cause for the degeneration of humanity. Such thinking indeed became a cornerstone of Nazi ideology and policymaking, and the Nuremburg Laws provide a vivid example of the Nazi conception of race and the role of the state in preserving the purity of blood of the "superior" racial class.

While the Nazi movement certainly invoked aspects of religious and economic anti-Semitism, racial anti-Semitism tended to be the strain most responsible for the massive scale of violence in the Third Reich. The concept of "racial hygiene" became a central part of both Nazi policy and propaganda, and was a primary justification for the extermination of those races viewed as inferior or sub-human. While religious and economic anti-Semitism were commonly based upon certain grievances against a particular group, racial anti-Semitism placed particular values on racial groups as human beings - consequently deeming some more worthy of life than others. Propaganda and the spread of racially discriminatory messages were central to allowing policies of violence and mass extermination to be carried out to the levels that they were. Klaus 
Voegel, the director of Dresden's German Hygiene Museum, which played an important role in spreading racial propaganda, has stated that, "The Hygiene Museum was not a criminal institute in the sense that people were killed here, but it helped shape the idea of which lives were worthy and which were worthless" (Rietschel, 2006). Once again, unlike with religious or economic anti-Semitism, individual Jews cannot overcome hatred and discrimination through means such as conversion or good deeds in the minds of those who subscribe fully to racially anti-Semitic ideology.

As is the case with other strains of anti-Semitism, data suggest that indeed elements of racial anti-Semitism existed within Germany even after the conclusion of World War II and the demise of the Nazi party. For example, in 1946, a plurality of West Germans answered "yes" to the question "Do you think Nazism was a good idea that was badly implemented?" - 47\% answering "yes" and 41\% answering "no." In fact, over the course of the following decade the percentage of those answering "yes" even increased: $55 \%$ in $1947 / 48,57 \%$ in 1948 , and $55 \%$ in 1969 . Those numbers eventually decreased over time with 26\% answering "yes" in 1977, 36\% in 1979, and 26\% in 1994 (Bergmann and Erb, 1997: 247). Indeed the ethno-nationalism, and particularly the anti-Semitic elements, was evident in other surveys as well. When asked "Would you say it would be better for Germany if there were no Jews in the country?" - 37\% answered "yes" in 1952, $26 \%$ in $1956,22 \%$ in $1958,18 \%$ in $1963,19 \%$ in $1965,9 \%$ in $1983,13 \%$ in 1987 , and 18\% in 1992 (Bergmann and Erb, 1997: 139). While the data indicate that these sorts of ethno-nationalist, anti-Semitic beliefs have generally declined over time, the data also indicate that the legacy of ethno-nationalist, racial anti-Semitism sustained in the decades following the fall of the Third Reich. 
The combination of ethnic nationalism and pseudo-scientific racial theories that originated in the nineteenth century were indeed predecessors to the Nazi ideology that endorsed genocide as policy. Data in the decades following World War II suggest that the influence of racial anti-Semitism continued even after the fall of the Nazi regime, so while the government may have fallen, the racially anti-Semitic propaganda and indoctrination had left a legacy that sustained in the following decades.

\section{e. Political Anti-Semitism}

Political anti-Semitism is closely related to economic anti-Semitism; however, political anti-Semitism often cites Zionism as the basis for numerous conspiracy theories. Consequently, political anti-Semitism is the most recent strain to arise in German society. Theodor Herzl, commonly viewed as the founder of modern political Zionism, first published his pamphlet entitled Judenstaat (Jewish State) in 1896, which outlined the rationale and philosophy behind the creation of a Jewish state. Herzl's work was indeed controversial, and was shortly followed by a number of works critiquing his philosophy, some of which were anti-Semitic and some of which were not. Nonetheless, some works, such as The Protocols of the Elders of Zion, depicted not only Zionists but Jews in general as pursuing not simply a Jewish state, but rather global power and domination via illegitimate and often criminal means. While anti-Semitism and anti-Zionism are not inherently related, there can indeed be connections and crossover between the two. This section will examine the historical development of political anti-Semitism in Germany and lead to an in-depth depiction of the current situation and problem.

As mentioned, The Protocols of the Elders of Zion in many ways originated modern political anti-Semitism and has indeed been a constant in the perpetuation of such 
beliefs. While The Protocols do invoke aspects of religious and economic anti-Semitism as well, the areas focusing on political power tend to be the most detailed sections and are indeed what made The Protocols different from the sort of anti-Semitic propaganda published prior to the twentieth century. The Protocols were written as a fraudulent text purportedly chronicling the minutes of meetings between Zionist/Jewish leaders and detailed plans for a takeover of global political power.

The Protocols depicts the establishment of a "Jewish super-state" as a goal that will ultimately subvert and enslave all other peoples. However, The Protocols does not depict the establishment of a Jewish state as a legitimate political undertaking, but rather a secretive conspiracy engineered for the ultimate goal of global domination and the submission of non-Jews. Protocol 7 states that, "The principal factor of success in the political is the secrecy of its undertakings" (Marsden, 2014: 26). Furthermore, The Protocols describe the concept of a Jewish state as a sort of nightmare scenario leading to terror and death (Marsden, 2014: 12). The text also invokes a number of characteristic stereotypes of Jews regarding greed, cunning, thievery - but broadens these stereotypes traditionally thought of in an economic sense and expands them into the political realm. So whereas economic anti-Semitism tended to depict Jews as seeking illegitimate financial gain at the expense of others, political anti-Semitism, and The Protocols in particular, depicted Jews as seeking illegitimate political gain, in the form of a "Jewish super-state" at the expense of others.

The Protocols were first published in German in 1920 and received immediate popularity, in part due to influential figures, such as the Hohenzollern family, defraying publication costs and actively distributing copies throughout the country (Pipes, 1997: 
95). The Protocols soon became an influential text during the Nazi rise to power and became widely studied in German schools (Segel and Levy, 1996: 42). The Protocols were especially effective in Germany, as they served the purpose of scapegoating Jewish conspiracies as the root cause of Germany's problems in the aftermath of World War I. As Nora Levin writes, "[The Protocols] were used to explain all of the disasters that had befallen the country: the defeat in the war, the hunger, the destructive inflation" (Levin, 1968: 19). Adolf Hitler even wrote of The Protocols in his Mein Kampf manifesto, "The important thing is that with positively terrifying certainty they reveal the nature and activity of the Jewish people and expose their inner contexts as well as their ultimate final aims" (Hitler, trans. 1998: 307-308). Joesph Goebbels similarly wrote that, "The Zionist Protocols are as up-to-date today as they were the day they were first published" (Pipes, 1997: 95).

As with other forms of anti-Semitism, political anti-Semitism has persisted since the end of World War II; however, this particular form became increasingly complex, and perhaps in some ways has intensified, since the establishment of the State of Israel in 1948. One such way that political anti-Semitism has manifested in the post-World War II era has been through Holocaust denial. One argument common in Holocaust denial circles is that the Holocaust was either a hoax or at least greatly exaggerated by Jews in order to gain leverage in convincing Western powers to enable the establishment of a Jewish state - a goal outlined in The Protocols (Herf, 2013) (Wistrich, 2012). In 1954, $13 \%$ of West Germans responded that they believed much of the Holocaust was exaggerated (Bergmann and Erb, 1997: 235). Holocaust denial theories received greater academic backing in the 1970's with the emergence of certain "revisionist" historians, 
such as Paul Rassinier and David Irving, who each questioned the statistics of those killed and Nazi culpability. Remarkably, data on Holocaust denial in Germany has remained consistent in the post-World War II era. In 1991, survey data demonstrated that $13 \%$ of Germans either agreed or somewhat agreed that Jews were at least partly to blame for their own persecution - the same percentage as in 1954 (Wetzel, 1997: 161). Another manifestation of anti-Semitic attitudes is the questioning of Jews' loyalty to their home country. A common accusation is that Jews as a group are difficult, if not impossible, to assimilate due to "divided loyalties" between their fellow Jews and their attachment to their home country. For this reason, some have labeled Jews a "nation within a state" or a "state within a state" (Katz, 1982: 124). With the establishment of Israel, this question of divided loyalties has stretched from not only loyalties to fellow Jews but also to Israel. A 1974 survey of West Germans asked whether or not respondents agreed or disagreed with the following statement, "Jews feel tied mainly to Israel. They are only marginally interested in the affairs of the country in which they live." Of those surveyed, 55\% expressed either strong or mild agreement, while $30 \%$ expressed strong or mild disagreement, and 15\% had no opinion (Bergmann and Erb, 1997: 145).

The same survey also asked respondents "Would you consider a Jew born and raised in Germany more a German or more a Jew?" While 65\% answered "more a German," 20\% answered "more a Jew," and 15\% were undecided. A 1982 survey posed a slightly different question asking, "Suppose there was a football game between Germany and Israel, and the spectators included German Jews. Whom do you think they would cross their fingers for, who would they root for?" $47 \%$ of the respondents believed the 
German Jews would root for Germany, $40 \%$ for Israel, and 13\% were undecided (Bergmann and Erb, 1997: 130-131). While not necessarily overt anti-Semitic behavior, the survey data do suggest a certain distrust among many Germans regarding Jews' loyalty to their home country and perhaps also a certain social distance between Germans and Jews. These suspicions among some Germans may lead some to "refuse to recognize German Jews as Germans, to deny them nationality" (Bergmann and Erb, 1997: 130). While this may in some cases be a subtler, non-violent form of anti-Semitism, it can often be considered a hostile attitude toward Jews, thus meeting the operational definition established as part of this analysis.

\section{References}

‘Anti-Semitism'. (2015) Merriam-Webster Dictionary. http://www.merriamwebster.com/dictionary/anti-semitism, accessed 28 February 2015.

Arendt, Hannah (1951). The Origins of Totalitarianism. New York: Schocken.

Aring, Paul Gerhard (1998). "Werner von Oberwesel". In Bautz, Traugott. BiographischBibliographisches Kirchenlexikon (BBKL) (in German) 13. Herzberg: Bautz.

Baron, Salo Wittmayer (1957). Social and Religious History of the Jews, Volume 4. Columbia University Press.

Bartulin, Nevenko (2013). Honorary Aryans: National-Racial Identity and Protected Jews in the Independent State of Croatia. London: Palgrave Macmillan.

Bergen, Doris L. (1996). Twisted Cross: The German Christian Movement in the Third Reich. Chapel Hill: UNC Press.

Bergmann, Werner (1997). Antisemitism and Xenophobia in German Since Unification, In: Kurthen, Hermann, Werner Bergmann and Rainer Erb (eds.) Antisemitism and Xenophobia in Germany After Unification. New York: Oxford UP, pp. 21-38.

Bergmann, Werner and Rainer Erb (1997). Anti-Semitism in Germany: The Post-Nazi Epoch Since 1945. New Brunswick, NJ: Transaction. 
Bermbach, Udo (2013). Wagner und Gobineau: Zur Geschichte eines Missverständnisses, WagnerSpectrum 9(1): 243-258.

Cohen, Jeremy (2007). Christ Killers: The Jews and the Passion from the Bible to the Big Screen. Oxford, UK: Oxford University Press.

Cohn-Sherbok, Dan (2006). The Paradox of Anti-Semitism. New York: Continuum

Cotler, Irwin (2009). Making the world 'Judenstaatrein', The Jerusalem Post, February 22: http://www.jpost.com/Opinion/Op-Ed-Contributors/Making-the-worldJudenstaatrein, accessed on 14 June, 2015.

Die Welt (2012). Türkische Migranten Hoffen auf Muslimische Mehrheit. Online publication, 17 August, http://www.welt.de/politik/deutschland/article108659406/Tuerkische-Migrantenhoffen-auf-muslimische-Mehrheit.html, accessed 5 July 2015.

Dimont, Max I. (2004). Jews, God, and History. London: Penguin.

Downs, Robert (2004). Books that Changed the World. New York: Signet.

Ehrenreich, Eric (2007). The Nazi Ancestral Proof: Genealogy, Racial Science, and the Final Solution. Bloomington, IN: Indiana UP.

Eidelberg, Shlomo, ed. (1977). The Jews and the Crusaders. Madison, WI: University of Wisconsin Press.

Ellis, Marc H. (2004). "Hitler and the Holocaust, Christian Anti-Semitism," Baylor University Center for American and Jewish Studies, slide 14.

European Monitoring Centre on Racism and Xenophobia (2006). "Antisemitism: Summary overview of the situation in the European Union, 2001-2005 (working paper)."

Flannery, Edward H. (2004). The Anguish of the Jews: Twenty-Three Centuries of Antisemitism. Mahwah, NJ: Paulist Press.

Fleischer, Tzvi (2007). Hate's Revival. Australia/Israel Review (AIJAC): http://www.aijac.org.au/news/article/hate-s-revival, accessed on 2 July 2015.

Gensicke, Thomas (2006). Jugend und Religiosität. In: Deutsche Shell Jugend 2006. Die 15. Shell Jugendstudie. Frankfurt a.M. 
Gerstenfeld, Manfred (2004). "'Something is Rotten in the State of Europe': AntiSemitism as a Civilizational Pathology. An Interview with Robert Wistrich", Post-Holocaust and Anti-Semitism, Institute for Global Jewish Affairs at the Jerusalem Center for Public Affairs, October 1: http://www.jcpa.org/phas/phas-25.htm, accessed on 28 November 2015.

Gesemann, Frank (2006). "Die Integration junger Muslime in Deutschland. Interkultureller Dialog - Islam und Gesellschaft Nr. 5.” Berlin: Friedrich Ebert Foundation.

Golb, Norman (1998). The Jews in Medieval Normandy: a social and intellectual history. Cambridge, UK: Cambridge University Press.

Gross, Jan (1979). Polish Society Under Occupation: The Generalgouvernment 19391945. Princeton, NJ: Princeton UP.

Gutman, Y., Mendelsohn, E. and Shmeruk, Ch. (eds) (1989). The Jews of Poland Between Two World Wars. Hanover, NH: UP of New England.

Herf, Jeffrey (2013). Anti-Semitism and Anti-Zionism in Historical Perspective: Convergence and Divergence. London: Routledge.

Hitler, Adolf (1998). Mein Kampf; trans. Ralph Mannheim. Boston: Houghton Mifflin.

Johnson, Paul (1988). A History of the Jews. New York: Harper Perennial.

Kamen, Henry (1998). The Spanish Inquisition: a Historical Revision. New Haven, CT: Yale UP.

Katz, Jacob (1982). A State Within a State: The History of an Anti-Semitic Slogan. Darmstadt.

Klug, Brian (2004). The Myth of the New Anti-Semitism. The Nation, February 2: http://www.thenation.com/article/myth-new-anti-semitism, accessed on 15 June 2015.

Korey, William (1995). Russian Antisemitism, Pamyat, and the Demonology of Zionism. London: Routledge.

Kramer, Martin (1995). “The Salience of Islamic Antisemitism.” Institute of Jewish Affairs Report (2): London.

Kreutzmüller, Christoph (2012). Final Sale - The Destruction of Jewish Owned Businesses in Nazi Berlin 1930-1945. Berlin: Metropol-Verlag. 
Lang, Berel (2009). Philosophical Witness: The Holocaust as Presence. Massachusetts: Brandeis UP.

Laqueur, Walter (2006). The Changing Face of Antisemitism: From Ancient Times to the Present Day. Oxford, UK: Oxford UP.

Lazare, Bernard (1903). Antisemitism: Its History and Causes. New York: International Library.

Levin, Nora (1968). The Holocaust: The Destruction of European Jewry 1933-1945. New York: Ty Crowell Co.

Levy, Richard (2005). Anti-Semitism: A Historical Encyclopedia or Prejudice and Persecution. Santa Barbara, CA: ABC-CLIO.

Lewis, Bernard (1999). Semites and Anti-Semites: An Inquiry into Conflict and Prejudice. New York: W. W. Norton \& Co.

Liang, Christina Schori (2013). Europe for the Europeans: The Foreign and Security Policy of the Populist Radical Right. Farnham, UK: Ashgate.

Lieu, Judith, John North, and Tessa Rajak (2013). The Jews Among Pagans and Christians in the Roman Empire. London: Routledge.

Luther, Martin (1971). On the Jews and Their Lies; trans. Martin H. Bertram, in Luther's Works. Philadelphia: Fortress Press.

Marsden, Victor (2014). Protocols of the Learned Elders of Zion. Bensonville, IL: Lushena Books.

Martin, Gus (2015). Understanding Terrorism: Challenges, Perspectives, and Issues. Thousand Oaks, CA: SAGE Publications.

Michael, Robert (2006). Holy Hatred: Christianity, Antisemitism, and the Holocaust. New York: Palgrave Macmillan.

Murphy, Cullen (2012). God's jury: the Inquisition and the making of the modern world. Boston: Houghton Mifflin Harcourt.

Pearson, Karl (1924). The Life, Letters, and Labours of Francis Galton. Cambridge, UK: Cambridge UP.

Penslar, Derek Jonathan (2001). Shylock's children: economics and Jewish identity in modern Europe. Berkeley, CA: University of California Press. 
Perry, Marvin (2002). Antisemitism: myth and hate from antiquity to the present. London: Palgrave Macmillan.

Pietikäinen, Petteri (2000). The Volk and Its Unconscious: Jung, Hauer and the 'German Revolution,' Journal of Contemporary History 35.4: 523-539.

Pine, Lisa (2010). Education in Nazi Germany. Oxford, UK: Berg.

Piotrowski, Tadeusz (1997). Poland's Holocaust. Jefferson, NC: McFarland and Company.

Pipes, Daniel (1997). Conspiracy: How the Paranoid Style Flourishes and Where It Comes From. New York: Simon \& Schuster.

Poliakov, Leon (1974). The History of Anti-semitism. New York: The Vanguard Press.

Rees, Laurence (2012). The Dark Charisma of Adolf Hitler. London: Ebury Press.

Rietschel, Matthias (2006). Nazi Racial Purity Exhibit Opens in Germany, MSNBC. 9 October: http://www.nbcnews.com/id/15197604/, accessed on 10 September 2015.

Rigg, Bryan Mark (2002). Hitler's Jewish Soldiers: The Untold Story of Nazi Racial Laws and Men of Jewish Descent in the German Military. Lawrence, KS: Kansas UP.

Riley-Smith, Jonathan (1991). The First Crusade and the Idea of Crusading. Philadelphia: University of Pennsylvania Press.

Sachar, Howard Morley (2005). A history of the Jews in the modern world. New York: Random House, Inc.

Sacks, Jonathan (2011). “The New Anti-Semitism is a Virus," Jewish Journal, 22 June: http://www.jewishjournal.com/at_home_abroad/item/uk_chief_rabbi_jonathan_sa cks_the_new_anti-semitism_is_a_virus_20110622/, accessed on 8 July, 2015.

Schreckenburg, Heinz (1996). The Jews in Christian Art. New York: Continuum.

Schweitzer, Frederick M. and Marvin Perry (2002). Anti-Semitism: myth and hate from antiquity to the present. London: Palgrave Macmillan.

Segel, Binjamin and Richard Levy (1996). A Lie and Libel: The History of the Protocols of the Elders of Zion. Lincoln, NE: University of Nebraska Press. 
Stirk, Peter (2002). Hugo Preuss, German political thought and the Weimar constitution. History of Political Thought 23(3): 497-516.

Tegel, Susan (2011). The Jew Süss: His Life and Afterlife in Legend, Literature and Film. London: Continuum.

Todeschini, Giacomo (2004). Franciscan Economics and Jews, In: Myers, Susan E. and McMichael, Steven J. (eds.) Friars and Jews in the Middle Ages and Renaissance, Volume 2. Leiden, Netherlands: Brill.

U.S. Holocaust Museum (2015). Jewish Population of Europe in 1945, 18 August: http://www.ushmm.org/wlc/en/article.php?ModuleId=10005687, accessed on 2 September 2015.

U.S. Holocaust Museum (2014). "The German Churches and the Nazi State," 20 June: http://www.ushmm.org/wlc/en/article.php?ModuleId=10005206, accessed on 1 July 2015.

Viereck, Peter (2003). Metapolitics: from Wagner and the German Romantics to Hitler. New York: Transaction Publishers.

Wagner, Richard (1869). Das Judenthum in der Musik. Leipzig: Weber.

Webb, James (1976). The Occult Establishment. La Salle, Illinois: Open Court.

Weil, Frederick (1997). Ethnic Intolerance, Extremism, and Democratic Attitudes in Germany Since Unification, In: Kurthen, Hermann, Werner Bergmann and Rainer Erb (eds.) Antisemitism and Xenophobia in Germany After Unification. New York: Oxford UP, pp. 110-142.

Weinthal, Benjamin (2013). "Synagogues in Germany Hit by Over 80 Attacks from 2008 to 2012." Jerusalem Post, 13 October: http://www.jpost.com/JewishWorld/Jewish-News/Synagogues-in-Germany-hit-by-over-80-attacks-between2008-and-2012-328633, accessed on 2 July 2015.

Wetzel, Juliane (1997). Antisemitism among Right-Wing Extremist Groups, Organizations, and Parties in Postunification Germany, In: Kurthen, Hermann, Werner Bergmann and Rainer Erb (eds.) Antisemitism and Xenophobia in Germany After Unification. New York: Oxford UP, pp. 143-173.

Wilson, William (1973). "Herder Folklore and Romantic Nationalism." Journal of Popular Culture 6 (4): 819-835.

Wistrich, Robert (2012). Holocaust Denial: The Politics of Perfidy. Berlin: Walter de Gruyter. 
Wolffsohn, Michael (1993). Eternal Guilt?: Forty Years of German-Jewish-Israeli Relations. New York: Columbia UP. 


\section{CHAPTER III}

\section{THE PROBLEM OF ANTI-SEMITISM IN POLAND}

\section{a. Religious Anti-Semitism in Poland}

The earliest mentions of Jews in Polish history date back to the tenth century, and their arrival was in large part a reaction to the persecution and anti-Semitism rampant across Europe at the time. Poland in many ways served as a refuge for European Jews, especially during the First Crusade in the late eleventh century. Whereas Jews had been the subjects of massacres, persecution, and banishment in other parts of Europe, Poland and its leaders had gained a reputation for tolerance and Jewish integration (Friedman, 2012: 9). However, it was not only Judaism that arrived in Poland at this time but also Christianity. Throughout its history, Poland had struggled with trying to ward off German expansion to the east, and one element of doing so was the first Polish King, Mieszko I, converting to Christianity in order to avoid armed conflict with the Saxons, who justified eastward expansion for the missionary purposes of converting pagan Poles (Cooper, 2000: 10). Therefore, it can be said that Judaism and Christianity arrived in Poland at nearly the same time, and their arrival was largely due to the religious persecution and missionary objectives of Poland's European neighbors.

Jews were generally welcomed into Polish territory in the centuries that followed, in part due to a Polish adherence to the political value of tolerance, but also the desire of Polish leaders to harness the knowledge and expertise that many European Jews brought

with them. This was especially the case under Boleslaw III, who ruled Poland from 11021139 and actively sought out European Jews and their expertise in order to develop the Polish economy. Many Polish municipalities also incorporated what was known as the 
Magdeburg Law, which was a charter that allowed Jews, along with others, to live under certain legal protections and established certain economic advantages allowing Jews a prominent role in the local economy (Abramson, 2013). Such conditions made Poland an attractive destination for many Jews fleeing oppression and this trend continued into the following centuries.

The tolerant environment that attracted many Jews to Poland was eventually affected by various influences, including the Roman Catholic Church and neighboring German states, which sought to roll back some of the tolerant policies that Poland had earlier adopted. The Church's Councils of Wroclaw (1267), Buda (1279), and Leczyca (1285) put pressure on Polish leaders to implement restrictions on Jews by segregating them from the Christian population, ordering them to wear special emblems noting their religion, banning them from holding public office, and restricting the number of synagogues built (Dubnow, 2001: 44).

Such restrictions on Jews were not, however, universally enforced. A number of prominent Polish leaders continued to act as protectors of Jews from persecution despite directives from the Church. For example, Duke Boleslaw the Pious, the Prince of Greater Poland, issued a General Charter of Jewish Liberties, known as the Statute of Kalisz in 1264, which guaranteed Jews basic freedoms with regard to trade, travel, and worship, as well as outlined specific penalties for those who would physically or otherwise harm Polish Jews. The Statute of Kalisz was significant, in that it also led to the adoption of similar laws by leaders across Polish territory in the following decades (Dubnow, 2001: 45). So while the Catholic Church did issue a number of decrees pushing for greater persecution of Polish Jewry, a number of Polish leaders, for various reasons, disobeyed 
these decrees and continued to maintain a relatively tolerant atmosphere for Jews compared to other parts of Europe.

Polish Jews were, nonetheless, targets of violent attacks due to religious motives such as blood libel, although to a lesser extent than in the German case. The first blood libel case recorded in Poland was in 1348, and this was followed soon after by the first pogrom in Poznan in 1367. Many Jews were also subjected to persecution around this time due to being scapegoated for the spread of the Black Death (Dubnow, 2001: 52). Such attacks were, however, discouraged and indeed punished by Polish leaders, namely King Casimir III the Great who ruled from 1333 to 1370. So while religious antiSemitism was indeed present in Poland during the early Middle Ages, as it was elsewhere across Europe, the scale of violence was lessened, in part due to the policies of Polish leaders at the time. Tensions between the Catholic Church and various Polish rulers continued throughout the Middle Ages, and although there were indeed occasional flareups of religious anti-Semitism and certain localities were harsher to Jews than others, the Polish political value of tolerance largely prevented widespread, systematic persecution. Although Polish leadership remained generally committed to protecting the state's Jewish community, flare-ups of anti-Semitic behavior remained evident during certain periods - and for the most part were motivated by religion. The fifteenth century in particular was marked by increases in Jewish persecution, due to several factors including dogmatic clergy pushing for less tolerance of Jews, the proliferation of blood libel accusations, and the continued scapegoating of Jews for spreading the Black Death (Dubnow, 2011: 22-24). In 1495, Jews were even ordered out of Krakow and were forced to resettle in the designated Jewish district of Kazimierz. Jews, for a period in the late 
fifteenth century, were also banished from Lithuania for a time. Near the end of the fifteenth century and early sixteenth, however, Polish leaders began to once again gravitate toward a policy of tolerance and removed many of the restrictions on Jewish life that had been implemented during the late fourteenth and early fifteenth centuries.

Throughout the seventeenth and eighteenth centuries, the Polish-Lithuanian Commonwealth was heavily impacted by violence due to the Cossack Uprisings, as well as invasions by the Swedish, Russian, and Ottoman Empires. Throughout these conflicts, Poles and Jews were both heavily affected and incurred death tolls in the hundreds of thousands (Schultz, 1982: 268). Poland's Jewish community suffered a great deal, particularly during the Cossack Uprisings, in large part due to the perception that Jews were allied with the Polish nobility (Hundert, 2004: 51). Indeed Polish rulers did remain generally supportive of Poland's Jewish community throughout the existence of the Commonwealth and Jews did not face the same sort of isolation as in other parts of Europe. In other words, Jews were often targeted by those opposing the PolishLithuanian state, rather than by the state itself. Gershon Hundert describes the integration of Jews in the Commonwealth by writing, "reports of romances, of drinking together in taverns, and of intellectual conversations [between Polish Catholics and Jews] were quite abundant" (Hundert, 2004: 51-52). However, the situation would later change due to the Commonwealth's dissolution and the partitioning of Poland by Prussia, Austria-Hungary, and Russia.

During the Third Partition of Poland from 1795 to 1918, the position of Jews in each partitioned territory differed. As Poland struggled to maintain its independence in the late eighteenth century, many historians note that most Jews were not indifferent and 
indeed fought alongside Polish leadership against external invasions, and that this led to a certain fraternity between many Poles and Jews (Orlicki, 1983: 21). However, Poland was eventually conquered by its neighbors and divided into three territories controlled by Prussia, Austria-Hungary, and Russia. The Prussian area was home to only a negligible population of Jews, but the Jews in the Prussian section were largely given equal rights. In the Austro-Hungarian section, Jews were prohibited from using the Yiddish or Hebrew languages in all public or legal institutions, but other than these restrictions were also provided equal rights. In the Russian section, Jews faced far greater restrictions on the practice of their religion, were pressured to integrate and, in many cases, convert to Christianity (Cooper, 2000: 24-25). Jews were restricted to living only within an area known as the Pale of Settlement and the Russian czars put great emphasis on attempting to assimilate the Jewish population of their newly acquired territory. The czars took such actions as prohibiting Hebrew or Yiddish curricula in schools, expelling Jews from many villages, and conscripted Jewish children as young as twelve years old into the military. Between 1827 and 1857, over 30,000 Jewish children were placed in military schools, in which they were pressured to convert to Christianity (Petrovsky-Shtern, 2009). There were indeed other manifestations of anti-Semitism from the late eighteenth through early twentieth century; however, the primary means through which religious anti-Semitism specifically arose were through these restrictions on religious practice, resettlement, and pressured conversion.

With the collapse of the German, Austro-Hungarian, and Russian Empires at the end of World War I, Poland was able to establish an independent state once again in 1918. Jews played a major role in the Polish liberation movement and many actively 
served under the direction of Josef Pilsudski, the movement's leader. The establishment of the newly independent Poland did, however, pose a major challenge to the resident Jewish community as Catholicism became more closely linked to Polish national identity. As Western Europe became increasingly secular ever since the Age of Enlightenment, Polish society tended to trend in the opposite direction as Catholicism became increasingly linked to Polish patriotism (Smolar, 1987: 32). The Jewish historian Shatzky wrote that: "Under the political conditions of the time, assimilation did not mean merely embracing Polish culture. The Roman Catholic Church played too important a role in the preservation of Polish culture to make it possible to separate Catholicism from Polonism" (Lichten, 1986: 112). Consequently, many Jews, in order to assimilate, began to adopt the majority faith of Catholicism. As Lee Cooper writes, "In the nineteenth and early twentieth centuries conversion meant a final step toward unity with the Polish people" (Cooper, 2000: 37). Many Poles, however, viewed Jewish assimilation as an infiltration of Polish culture by a group that held alien and hostile values. This led to an increased emphasis on the "Jewish Question" among the Polish intelligentsia. The prevailing belief among the conservative, clergy-dominated faction advocated that Jews "renounce their religion and their national peculiarity in favor of complete assimilation or that they should leave Poland" (Cooper, 2000: 38). Therefore, in the aftermath of World War I and the establishment of the newly independent Poland, the Polish political value of religious tolerance began to erode as Jewishness became increasingly disassociated and unwelcomed as part of Polish national identity.

Poland during the interwar period experienced severe conflict between those who sought to uphold the political value of tolerance and pluralism and those who sought to 
establish a Catholic state of the Polish nation. As part of the Paris Peace Conference, a Minority Rights clause was applied to Poland with special mention of Jewish minorities, whom accounted for nearly ten percent of the country's total population (Tomicki, 1982: 310). Josef Pilsudski, commonly viewed as the liberator of Poland and eventual leader after a 1926 coup, tended to adhere to the value of tolerance and acted as a protector of the Jewish community. However, Pilsudski was in conflict with the National Democratic Party (Stronnictwo Demokratyczno-Narodowe - SDN), which held that only those of the Polish race and Christian beliefs qualified for citizenship (Black, 1987: 15). The National Democrats had substantial support among university students, the Polish intelligentsia, as well as a number of clergy. In fact, Polish bishops issued a pastoral letter on December 5, 1927 calling on all Catholics to support the anti-Semitic National Democrats in upcoming elections (Cooper, 2000: 49). A core belief of the National Democrats was that a Pole was meant to be a Christian, and a Jew was an alien element distinct from a Pole.

After Pilsudski's death in 1935, the situation for Poland's Jewish community drastically worsened as the National Democrats and their supporters seized the opportunity to push for the establishment of a Catholic state and sought to provide an answer to the "Jewish Question." Anti-Jewish student campaigns, largely supported by the Catholic Church, organized a pilgrimage to the town of Czestochowa in 1936 that attracted 60,000 students or sixty percent of all Polish students. At the demonstration, the students vowed "to build a Catholic state of the Polish nation" and declared that "we will not rest until the last Jew, alive or dead, has left Polish soil" (Cooper, 2000: 59). Catholic publications also emphasized the religious aspects of the "Jewish Question" by publishing numerous articles on the immorality of the Talmud and the destructive nature 
of Jewish ethics and culture (ibid: 62). Many Polish Catholics viewed Jews as the primary obstacle to their goal of an official Catholic state of Poland. Consequently, the demonization of the Jewish religion that for centuries had been largely tolerated in Polish society, became a powerful and widespread tool in controlling crowds and igniting passions.

By the time of the Nazi invasion of Poland in 1939, significant cleavages existed between segments of Poland's Catholic and Jewish populations; however, not all Poles were uniform in their relations with Jews. The Nazi German invocations of religious antiSemitism, commonly based on the writings of Martin Luther, did not have equal resonance in Poland due to the differing religious traditions in each country. Nonetheless, many Jews had already been alienated by certain Catholic nationalist segments of Polish society. Although the goal of a Catholic Polish state diminished with the Nazi occupation, the Nazis were able to exploit tensions between Poles and Jews. Despite unsuccessful attempts to enlist official Polish collaboration, some Poles were cooperative in Nazi German plans for the deportation of Jews and the implementation of the Final Solution. Groups such as the Blue Police actively assisted the Nazis in capturing, deporting, and even executing Jews (Ringelblum, 1985: 309-310).

Nonetheless, elements of the Polish resistance differed in the treatment of Jews; while some reports claim that Polish resistance movements were responsible for the executing Jews, other groups, such as Zegota, were known to have made rescuing Jews a primary mission. Many of those who viewed Jews as a hindrance, or even enemy, of the Polish state during the interwar period continued to do so during the Nazi occupation (Cooper, 2000: 144-147). Meanwhile, groups such as Zegota would often invoke 
Catholicism as means to protect Polish Jews. One of the co-founders of Zegota wrote that "anyone who remains silent is an accomplice; he who does not condemn condones" (Tomaszewski and Werbowski, 1994: 13). Other Zegota literature stated that those who do "not support our protest is not a Catholic" (Prekerowa, 1992: 162). So while religion's role in Polish society often served as a point of tension between Poles and Jews, others viewed religion as a call to aid the persecuted Jewish population.

The Holocaust decimated Poland's Jewish population, reducing the 1939 number of 3.6 million to only about 100,000 by 1945 (Yivo Institute for Jewish Relations, 2010). Nonetheless, anti-Jewish violence continued within Poland's borders due to a series of blood libel rumors through 1946 reminiscent of events centuries earlier. The Krakow pogrom commenced on August 11, 1945 following accusations that a Jewish woman attempted to kidnap a Polish child and the alleged discovery of corpses of Christian children in a local synagogue. This led to riots in the city, in which at least one Jew was killed and a synagogue was set aflame (Cichopek, 2003: 224). This event was followed by blood libel accusations and violence in about a dozen Polish towns - the most controversial and impactful of which occurred in the town of Kielce (Piotrowski, 1997: 136). The brutality of the Kielce pogrom led many of the remaining Polish Jews to emigrate and begin a new life abroad. By Spring 1947, tens of thousands of Poland's remaining Jews had fled leading to a virtual absence of the country's Jewish community that had existed for nearly a millennium (Bernhard and Szlajfer, 2004).

In the decades during communist rule in Poland, the state was known to use antiSemitic tendencies for various political purposes, but religious anti-Semitism typically gave way to other manifestations. There is no reliable data available that traced anti- 
Semitic trends in communist Poland and also few examples of religious anti-Semitism motivating incidents of violence, in part due to the relative lack of Jews in the country during this time and also a general de-emphasis of religion during communist rule. However, data taken since the fall of communism has shown that religious anti-Semitism, in particular allegations of deicide, tend to have greater resonance in Poland than anywhere in Western Europe. A 2005 survey conducted by the Anti-Defamation League showed that Poland had nearly twice as many respondents (39\%) answer 'yes' to the statement "Jews are responsible for the death of Christ" than the next highest country Denmark (22\%) (Anti-Defamation League, 2005). The fact that religious anti-Semitism is higher in Poland than most countries seems to correlate with the fact that Poland also remains one of the most religious countries in Europe. $87.5 \%$ of Poles claim Catholicism as their religion, $63 \%$ of who attend church on a weekly basis (Central Statistics Office, 2011) (Gallup, 2004). While there have not been any significant incidents of blood libel since the Kielce pogrom in 1946, the fact that deicide remains a major source of antiSemitism in Poland demonstrates that the religious strain of the problem continues to remain an issue, and substantially more so than in countries with lower levels of religiosity.

\section{b. Economic Anti-Semitism in Poland}

Ever since their arrival in Poland a millennium ago, Jews played an integral role in the development of the Polish economy. In fact, historians frequently cite the productivity and expertise of the Jewish community as a primary reason for Poland's welcoming attitude toward Jews and longstanding emphasis on religious tolerance (Cooper, 2000: 10). Polish kings were known to have implemented certain policies in 
order to attract Western European Jews to help develop the primitive Polish economy in the thirteenth century - the Statute of Kalisz is one example of such policies (Abramsky et al., 1986: 3). At a time of near universal illiteracy, European Jews were able to bring certain knowledge and economic expertise to Poland, and in return received the promise of a tolerant society in which to live. Many of the Jews who settled in Poland came from Germany and had an expertise in finance due to the reasons described in the earlier portion of this chapter. Consequently, historical records indicate that Jews were granted the minting of Polish coins as early as the twelfth century. And as towns began to rise in the thirteenth and fourteenth centuries, Jews were often responsible for helping to obtain the capital and financial resources necessary to develop industries, primarily agriculture, for the nobility (Cooper, 2000: 11-12). These factors led to Jews commonly assuming prominent roles in the Polish economy, but this reality has also led to certain grievances and resentment among some known as economic anti-Semitism.

The relative success of Jews in Poland's economy resulted in certain grievances and hostility often focusing on the competition that Jews posed to Christian merchants. Pamphlets in the sixteenth and seventeenth centuries often combined religious accusations against Jews complemented by a focus on economic competition. These sorts of arguments tended to depict mere Jewish participation in commerce as a crime. Common arguments were that Jews "take the trade away from the city [and the Christian merchants]" (Mahler, 1942: 116) and "corrupt judges with gifts and the lords with bowing" (Hundert, 1986: 49). Such arguments not only depicted Jews as a threat to the economic wellbeing of Christians, but also undermined the legitimacy and ethics of Jewish involvement in commerce. 
As Poland was occupied and partitioned by its neighbors in the late eighteenth century, Jews provided a convenient scapegoat for the economic misery experienced across Polish territory. Even though many Jews fought alongside Polish nationalists to maintain the sovereignty of the Polish state, anti-Semitic propaganda began circulating in the late eighteenth century demanding the expulsion of Jews from the cities and be resettled as peasants or laborers on public works projects. These pamphlets described Jewish economic influence as "the plague," a "contagion," and "putridness." A common argument in such literature was that Jews were "taking away the bread from Christians" and thus needed to be subjugated to a lower rung of the economic ladder (Mahler, 1942: 126). These types of arguments asserted that the Polish economy's reliance on Jews in various sectors was an inherent weakness that enabled the fall of the sovereign Polish state. This became a popular theme and invocation of economic anti-Semitism among nationalist movements.

Economic anti-Semitism continued into the twentieth century, in large part due to the influence of the National Democratic Party and its exploitation of anti-Semitic feelings. Even prior to WWI and the establishment of a newly sovereign Poland, the SDN began organizing economic boycotts against Jews in 1909. Common slogans of the group were "Do not buy from the Jews!" and "stick to your own kind" (Cooper, 2000: 32). However, the stereotype that Jews consisted entirely of rich people, as was common in Western Europe, tended to have less resonance in Poland, due to the dire poverty that many Jews in small towns and the Jewish districts of major cities experienced. Still, Polish anti-Semitic groups depicted the lower class living conditions of many Jews as a threat to the future of Polish society. Polish historian Jeske-Chojenski explained the 
poverty of Polish Jews as follows: "Amidst the cold and frost the Jew lives a whole day on a piece of herring, on a crumb of bread watered down with brandy and greased with a head of onion or garlic. A Polish dog would die with such a diet, yet the Jew feels fine and multiplies like sand on the seashore" (Jeske-Chojenski, 1913: 90). This sort of depiction painted Jews as a sort of pest that "multiplies" despite their living conditions or economic wellbeing. In other words, economic anti-Semitism could be aimed at Jews of varying economic classes - the stereotype of the greedy, wealthy Jew on one hand and the "multiplying," impoverished Jew on the other - with both constituting threats to Polish society.

From its foundation, the SDN had in its platform plans to "de-Judaeise" the Polish economy, but in the 1920 's the emphasis on such a program increased drastically as the newly independent Poland engaged in active conflict with the Russian Bolsheviks. As conflict between Poland and Soviet Russia broke into a full-scale war in 1920, Polish Jews overwhelmingly supported the Polish war effort with many serving in the military on the front lines. Nonetheless, even as the Soviet Army withdrew, many Poles continued to accuse Jews of collaboration with the Bolsheviks. Such accusations were part of widespread propaganda that proclaimed Bolshevism was a creation of the Jews. Common anti-Semitic propaganda at the time depicted Red Army soldiers carrying white and blue flags with the Star of David (Cooper, 2000: 45). Such propaganda was accompanied by pogroms in a number of cities, and military tribunals were set up to prosecute alleged Jewish 'spies,' many of who were executed (ibid.). Given the historical tensions between Poland and Russia, tying the Jewish community in Poland with the Bolshevik ideology acted a means to create an enemy by alleged association. The accusation that Jews are a 
disloyal and untrustworthy group due to certain minority characteristics is a common theme in economic anti-Semitic rhetoric and ideology, and forging connections between Polish Jews and Bolshevism only served to further such attitudes.

Anti-Semitic sentiment in Poland was also fueled in the 1920's and 30's by the onset of the Great Depression. Polish Jews provided a convenient scapegoat for the widespread unemployment and dire economic circumstances across the country. The same themes of Jews being depicted as competitors and exploiters of other Poles were common, even though the living conditions and income levels of Polish Jews were on average lower than for most other Polish industrial workers (Gutman, 1989: 102). As jobs became increasingly scarce for all workers in Poland, the situation was even worse for Jews due to increasing employment discrimination. While Jews accounted for ten percent of Poland's population in 1923, only 2.23 percent of government employees were Jewish and that number declined to only one percent by 1930. Furthermore, Jews accounted for thirty percent of Poland's urban population, but only two to three percent of municipal employees (Ben-Sasson, 1976: 955-956). There were even reports of Jews being denied employment opportunities at Jewish-owned businesses due to the objections and unwillingness of some Christian workers to work with Jews. There were also numerous boycotts of Jewish shops and signs placed on certain storefronts to denote the religion of the owner (Cooper, 2000: 53). The dire economic circumstances of the Great Depression allowed a number of historical manifestations of economic anti-Semitism to arise once again and, in many cases, intensify. At a time when the newly established Polish state was struggling with questions regarding the role of religion in the state's identity, the dire 
economic circumstances of the depression led to both the religious and economic manifestations of anti-Semitism to complement one another and grow.

Knowing that anti-Semitic sentiment had grown in Poland during the interwar period, the Nazis exploited tensions between Poles and Jews in order to carry out their goals in implementing the Final Solution. A primary area upon which the Nazis focused was tension over economic competition between Poles and Jews. Soon after the Nazis had overtaken Warsaw, the German NSF (National-Sozialistische Folkswohlfahrt) organized centers for the free distribution of bread. These bread lines were created not only for propaganda purposes, but also to stoke feelings of economic anti-Semitism. In order to shorten the queues, Poles were incentivized to identify the Jews among them and have the Jews removed from the queue (Ringelbaum, 1985: 255). Economic incentives were also a common tactic by the Nazis to coerce Poles into providing information about their Jewish neighbors. Severe penalties, including death, were commonly applied to those hiding Jews, but monetary and other awards, including the belongings of captured Jews, were promised as bounties. This was a common tactic, particularly in rural areas, where virtually all residents knew one another (ibid: 313). Many Polish peasants also benefitted from Nazi policies that cancelled debts owed to Jewish creditors and the elimination of certain taxes (Cooper, 2000: 91).

Consequently, some historians cite economic anti-Semitism as a primary reason why many Poles did not provide greater resistance to the Nazi atrocities committed against Polish Jews. As Richard Lukas wrote:

Despite German persecution of the Polish people, a small minority of Poles openly approved of German policies toward Jews, and some actively aided the Nazis in their task. Other Poles showed no outward pleasure at the removal of 
Jews from Polish offices, professions, and businesses but were not opposed to the economic expropriation involved. These people had anti-Semitic views which were economic, not racial, in character; it reflected an economic anti-Semitic attitude. (Lukas, 1986: 126)

Therefore, while many Poles did not actively seek, or even participate in, the atrocities committed against Polish Jewry by the Nazis, some were accepting of the removal of Jews from economically significant positions - similar to the process to "de-Judaeise" the economy that had been an emphasis of the SDN since the early twentieth century. So in many ways, the exploitation of economic anti-Semitism by the Nazis was not necessarily a new concept within Polish society, but rather the Nazis worked to exploit enduring economic tensions between Poles and Jews, particularly as it relates to economic competition.

Although nearly all of Poland's pre-WWII Jewish community was either killed in the Holocaust or had emigrated soon after the war, economic anti-Semitism and Jewish persecution in general did not cease under the post-war communist government. Following Stalin's death and the consolidation of communist rule in Poland, there were a number of workers' disturbances in the city of Poznan and a general discontent among the Polish people regarding the failures of Stalinism and the communist system. After assuming power in 1956, the government under Wladyslaw Gomulka began to search for a scapegoat to divert public attention away from domestic economic failures and ineffective policy measures. The legacy of the preceding decades made Jews an easy target, and thus an anti-Semitic campaign was unleashed (Cooper, 2000: 206-207). The Gomulka government purged Jews from top positions in the party, sensitive posts in the government, as well as from the army (Dawidowicz, 1993: 97). In 1950, there were only 
about 45,000 Jews left in Poland with more emigrating in subsequent years. Yet even though Poland had been nearly ridden of its pre-WWII Jewish population, anti-Semitism continued to exist in an environment nearly absent of Jews (Cooper, 2000: 206). Thus, it was not necessarily the presence of Jews that spurred the anti-Semitic sentiment under the communist regime, but rather an historical legacy of anti-Semitism and conspiratorial beliefs about the role and influence of Jews in society.

Anti-Semitic propaganda became characteristic of the communist government's strategy, not only for the purpose of scapegoating a particular people for the regime's failures but also to seize property and wages and exploit domestic economic competition in much the same way as the Nazis and the SDN. Poland's communist leaders, and especially the Gomulka government, enacted a campaign of psychological terror on Polish Jews in order to pressure emigration. All Jews in communist Poland were registered by the Ministry of Internal Affairs and were pressured to emigrate via anonymous letters, phone calls, threats, loss of employment, and vandalism. Consequently, many Jews committed suicide, families became separated, and those who did decide to emigrate were often left little choice but to sell their possessions to stateowned shops for excessively low prices. Many Poles benefitted from the economic oppression of the Jewish population by obtaining the jobs and occupying the homes of fleeing Jews - similar to the circumstances during the Nazi occupation. Such conditions damaged the image of Poland abroad, so the government initiated counter-propaganda abroad claiming that such persecution did not exist. In 1968, Polish diplomat Jan Druto claimed in Paris that "the majority of the tiny Jewish community was deeply attached to their country" (Cooper, 2000: 220-224). So while the communist government attempted 
to portray a positive image abroad, its anti-Semitic agenda domestically went beyond mere scapegoating and into outright economic persecution reminiscent of the Nazi occupation.

\section{c. Racial Anti-Semitism in Poland}

Although racial anti-Semitism in Poland historically tended to lack the sort of pseudo-scientific eugenics element of the German variety, ethnic nationalism was often a key motivation behind anti-Semitism in Poland throughout the twentieth century. Racial anti-Semitism is one of the more recent manifestations to arise in the Polish case, not having taken hold with great affect until the rise of the SDN and formation of the newly independent state in 1918. The establishment of the new Polish state reignited debate over what it meant to be Polish, and, further, what place minority populations had in such a state. As with many nationalist movements, culture played a central role in the debate of what constituted 'Polishness.' Despite the fact that Jews had historically been influential in Poland's intellectual and cultural circles, many viewed such influence as illegitimate and not sufficiently reflective of the typical Pole. Those Jews who sought to assimilate, even via conversion to Christianity, would often be dismissed as not true Poles. Therefore, in many cases anti-Semitism stretched beyond merely a prejudice of certain beliefs or values, and into the realm of prejudice against one's ethnic makeup or inherent 'Jewishness.'

In the nineteenth century, many Polish Jews sought to fully assimilate with the majority of Poles and thus spoke the Polish language, adopted the culture, and many even converted to Christianity (Lichten, 1986: 112). However, not all Poles welcomed such a development. Many Poles became concerned about what they believed to be the 
'Jewification' of Polish culture; that Jews were intruding on Polish identity (Cooper, 2000: 37). These sorts of allegations parallel those in Germany by figures such as Richard Wagner, who had similar concerns in the German case. Although the sorts of pseudo-scientific theories that were widespread in Germany did not achieve equal prominence in Poland, the Polish intelligentsia, and especially university students, became some of the most vehement propagators of racial anti-Semitism.

Amid concerns that Jews were 'polluting' the Polish culture and entering higher education in excessive numbers, Poznan University implemented a discriminatory quota system in 1919 that limited the number of Jews who could attend university. This policy was followed by rallies at numerous other universities across the country where students demanded similar policies be implemented. In February 1928, students at Krakow University demanded complete segregation of Jews at the university, and, following violent clashes at Warsaw University, the quota system expanded across the country. By 1931, the SDN and various student groups were no longer calling for quota systems, but for the total elimination of Jews from Polish universities (Cooper, 2000: 56-59). As the Nazis rose to power in neighboring Germany in the 1930's, universities in Poland became the one area of Polish society where Nazi racial propaganda most resonated. In spring 1937, amid pressure from student organizations, university rectors and deans introduced special seating for Jewish students nicknamed 'ghetto benches' that fomented an atmosphere of constant harassment. By 1938, students of Jewish origin (not only Jewish faith) were barred from joining student organizations. At this time, students also began demanding that anti-Jewish legislation similar to the Nuremburg Laws be enacted in Poland (Rudnicki, 1987: 264). The sort of ethnic nationalism on the campuses of many 
Polish universities in the early twentieth century mirrored many of the developments in Germany at the time and made these campuses particularly fertile grounds for the propagation of racial anti-Semitism. Universities became one of the first institutions in Poland where Jews became discriminated against not only for their faith and beliefs, but also racial and ethnic makeup.

A primary reason behind the growing strand of ethnic nationalism in early twentieth century Poland was that while many Jews were willing to assimilate, and even convert, there remained a certain level of distrust among many Poles for Jews regardless of any efforts toward assimilation. This dynamic put Polish Jews in a precarious position: either be accused of separateness on the one hand or of intrusion into Polish culture on the other (Cooper, 2000: 52). This sort of no-win situation is characteristic of racial antiSemitism - whereas one can change one's beliefs, one cannot change one's ethnicity thus, racial anti-Semitism allows for no remedy. These factors make violence particularly likely in cases where racial anti-Semitism manifests. Even prior to the Nazi occupation of Poland, there were a series of pogroms across the country from 1934 to 1939 where 500 Jews were murdered, 30 of who were university students, and about 5,000 were wounded (ibid: 67). In some instances, Jews did resist the violence perpetrated against them, but these actions were often futile, as any Christian casualties were often treated as an act for which Jews would be held collectively responsible (Gutman et al., 1989: 129).

The ethnic nationalism within interwar Poland in some ways paralleled the racially anti-Semitic propaganda of Nazi Germany. In fact, one Polish parliamentarian in 1936 proposed a plan that would deprive Jews of civil rights, confiscate assets, and incarcerate about 600,000 Jews in concentration camps (Cooper, 2000: 72). This plan 
was intended to not only persecute domestic Jews, but also create conditions pressuring the rest to emigrate. Although these measures were merely a proposal, there was indeed traction for such ideas within ethnic nationalist segments of the Polish population.

While Nazi racial ideology did consider Poles to be on a lower stratum of the Aryan race, Poles were nonetheless considered Aryan, and thus there remained a clear divide between Poles and Jews during the Nazi occupation. The Nazis did indeed commit massacres targeting the leading strata of Polish society, but such actions were largely not taken against unskilled workers, peasants, and others who could essentially be forced to work under Nazi leadership (Gross, 1979: 76). Jews, on the other hand, were targeted for extermination, regardless of occupation or skill. Thus, the Nazi targeting of Poles was intended to ensure submissiveness and obedience, whereas Nazi targeting of Jews was intended to result in absolute extermination.

The living conditions within Nazi occupied Poland were intended to foment an atmosphere in which animosity between Poles and Jews was exploited. In cities, Jews were confined to the Jewish ghettos, while Poles lived on the Aryan side. Jews on the Aryan side lived in an extremely dangerous situation, as the consequences of being caught were universally severe. The Nazis applied a carrot and stick method to coerce Poles into turning over fugitive or hidden Jews, and the sheer terror and psychological stress of avoiding recognition led many Jews to return to the ghettos (Ringelbaum, 1985: 291). Necessities as simple as seeing a doctor when ill were particularly dangerous, as there were numerous cases of doctors reporting Jewish patients to authorities (ibid: 300 ). Such an atmosphere conditioned many Poles to believe, or at least live by, the Nazi ideology that viewed Jews as inherently lesser and devalued human beings. 
Following the end of WWII and the Holocaust, the sort of racial anti-Semitism that had been so prominent during the Nazi occupation greatly lessened, but did nonetheless leave a certain legacy, as in the German case. Racial anti-Semitism did not play a major role in the anti-Semitic propaganda under communist rule, although some survey data and rhetoric from anti-Semitic groups have shown that racial anti-Semitism continued to exist. Data on anti-Semitism in communist Poland is scarce, but a 1988 survey showed that $23 \%$ of Poles would not accept a blood transfusion from a Jew and 40\% would advise a friend against marrying a Jew. By 1998, however, these numbers dropped to $15 \%$ and $33 \%$ respectively (Sulek, 2012: 431). There also remains a fascination or even admiration among some anti-Semitic Poles for the Nazi agenda toward Jews, as evidenced by certain incidents attacking Jewish interests. In September 1990, a monument erected at the Umschlagplatz in Warsaw, where 350,000 Jews were sent to concentration camps, was defaced by graffiti with the words "a good Jew is a dead Jew." Around the same time in Warsaw, youth demonstrators burnt the effigy of Prime Minister Oleksy decorated with a Star of David and shouting that Jews ought to once again be sent to the gas chambers (Cooper, 2000: 226). These sorts of incidents continue to be a symptom of racial anti-Semitism and the belief that Jews as an ethnicity or race deserve to be discriminated against or attacked. While racial anti-Semitism may not be the predominant form in the Polish case, it is historically one of the most violent manifestations and therefore remains an important problem where it exists regardless of its prominence. 


\section{d. Political Anti-Semitism in Poland}

As has been mentioned, political anti-Semitism is the belief that Jews are in constant pursuit of global political power for mischievous purposes, and is often complemented by conspiracy theories and scapegoating. As in the German case, this strain of anti-Semitism rose to prominence in Poland during the twentieth century and has been heavily influenced by reactions to Zionism. Polish ethnic nationalism of the early twentieth century sought to create a homogenous Catholic state in which Jews were unwelcome. In order to attract followers, the SDN and other ethnic nationalists exploited suspicions about Poland's Jewish community and their loyalty to the country. As nationalist discrimination against Jews increased in the 1920's and 1930's, a growing number of Jews joined the Zionist movement, which only exacerbated nationalist suspicions and led some to believe that Jews were more loyal to Zionism than Poland (Cooper, 2000: 72). This dynamic was influential in decreasing social trust between Poles and Jews and gave rise to conspiracy theories about the ultimate aims of Polish Jews.

Beginning in the 1930's, the idea of forced, or at least strongly pressured, emigration gained traction among Polish anti-Semitic groups and individuals. At times, these groups and individuals have advocated distorted versions of Zionism to justify their motives and accomplish their goals. In 1936, the Polish government at the annual meeting of the League of Nations even proposed a scheme demanding the allocation of colonies where Polish Jews could be resettled. Only one month later, Jozef Beck, Poland's Minister of Foreign Affairs, made an official request to international banks to help finance a mass emigration of Polish Jews (Cooper, 2000: 72). These were proposed answers to the 'Jewish Question' in interwar Poland. However, whereas Zionism 
typically implies voluntary Jewish resettlement to a designated homeland, many of the proposals at this time called for a forcible resettlement.

The calls for forced Jewish emigration were not limited to one decade and indeed carried on throughout twentieth century Poland, despite the various periods of foreign occupation. One of the most prominent examples of political anti-Semitism and its influence is demonstrated by the case of Polish politician Boleslaw Piasecki. Piasecki was the leader of the ultranationalist ONR-Falanga Party, founded in 1935, and called for the "systematic and radical elimination of Jews from Poland" (Cooper, 2000: 208). Piasecki's goal was to facilitate an anti-Jewish atmosphere in Poland that would force a mass exodus of Polish Jews and 'free' Poland from the perceived Jewish influence in government and society (Gutman, 1985: 9). Piasecki and his movement, however, were not constrained to the 1930's. Although the ONR-Falanga disappeared during the Nazi occupation, Poland's post-war communist government adopted many of the same themes in anti-Jewish propaganda. In 1947, Piasecki founded the PAX Association that carried on a similar ideology albeit with a more pro-communist stance. Piasecki was even appointed a member of the Council of State of the Polish People's Republic - the supreme state authority - and became an important figure in stirring up the anti-Semitic propaganda of the communist regime (Cooper, 2000: 208). Piasecki is only one example, but is nonetheless a personification of the sort of political anti-Semitism that manifested in Poland in the early twentieth century and has survived despite periods of foreign occupation.

As discussed in the preceding sections, each strain of anti-Semitism had a presence around the time of the Holocaust and its immediate aftermath, but political anti- 
Semitism in particular increased following the establishment of the State of Israel. This was especially true in 1967 in the aftermath of the Six-Day War. Many Poles celebrated the decisive Israeli victory, not necessarily out of a love for Jews or Israel itself, but rather the setback suffered by the communists and their allies. Some Poles were even happy that what they considered "our Jews" - those who used to reside in Poland - were responsible for the communist setback (Kunicki, 2012: 153-155) (Cooper, 2000: 209). This reaction was met with discontent from the communist regime, which responded by initiating a mass campaign of anti-Semitic propaganda disguised as anti-Zionism.

In June 1967 , the Gomulka government publicly criticized Jews as a potentially dangerous "fifth column," and as people having "two fatherlands" and a "double allegiance" who therefore could not be trusted (Cooper, 2000: 209). These accusations served as a pretext for the removal from the party and administrative posts any member who was considered to be of Jewish origin. Although according to Polish law at the time individuals were not required to state their religion on identity documents, the government nonetheless compiled a confidential list of those considered Jewish based on information supplied by other Poles (Banas, 1979: 90). The environment of anti-Semitic persecution created by the Gomulka government contributed to the mass exodus of many of the remaining Polish Jews - a situation that the government further exploited to serve its propaganda messaging. Those Jews who did decide to emigrate were often coerced into making statements and signing documents that depicted them as disloyal and even treasonous. Each Jewish applicant for emigration was forced to sign a document renouncing their Polish citizenship and asked to declare that they felt more affinity to Israel than Poland (even those not emigrating to Israel) (Davidowicz, 1993: 110). These 
sorts of measures notably aligned with the themes propagated in texts such as The Protocols of the Elders of Zion, which continues to be distributed in anti-Semitic circles within Poland (Cooper, 2000: 211). In short, these measures sought to more closely connect anti-Zionism with anti-Semitism by depicting Jews as collectively disloyal to Poland and its national interests.

This emphasis on anti-Semitism by the communists served an additional purpose of the government, which was to keep nationalist sentiment subdued. Nationalist movements throughout Eastern Europe were a potential threat to Soviet-directed communist governments and one means of placating such movements was by identifying a common "enemy," which had for many nationalists historically been the Jewish community. As Lee Cooper writes, "Nationalism requires the existence of an enemy of the nation; anti-Semitism served that purpose" (Cooper, 2000: 219). The anti-Semitic campaign by the state was in part intended to take nationalist aggression toward the regime and redirect it toward Jews. Indeed such measures were not entirely successful, as many nationalist movements continued to hold antipathy toward the regime, but others such as the PAX Association led by Piasecki did align with the communist-led antiSemitic campaign and supported the government's actions.

Unlike in the German case, Holocaust denial tends to be much less prevalent in Poland. The controversy, however, tends to lie in how the victims should be honored and who exactly the victims of the camps were. Controversy arose at Auschwitz in 1989 when Catholics erected a cross at the camp during a visit by Pope John Paul II. Those in support of the cross's placement argued that it was to honor the 100,000 Poles killed at the camp, while others see the cross as a means to discount the over one million Jews 
killed there. By 1998, there were approximately 240 crosses placed at the site, and the resulting controversy created even greater tension between Poles and Jews over the question of who suffered more under the Nazi occupation (Tal, 1999) (Zubrzycki, 2006). Casimir Svitin, the caretaker of the crosses, has expressed certain anti-Semitic rhetoric and conspiracy theories about Jews and has even stated that the crosses are an act of defiance against Jewish influence in Poland. Svitin has argued that, "The Jews want to exploit us, they want to take power in Poland, but these Christian symbols prove that we will not submit to their blackmail" (Cooper, 2000: 233). Others have been even more forceful in denouncing sympathy for the Jewish Holocaust, such as Henryk Jankowski, a Gdansk-area priest, who stated "the shield of David is intertwined with the swastika in the same way as is the sickle and the hammer" (ibid: 230). So while Holocaust denial tends to be less common in the Polish case, many view sympathy for the victims as a sort of zero-sum game where it is either Poles or Jews viewed as victims of the genocide but not both. Themes of political anti-Semitism also seep into this controversy with statements, such as those by Svitin, which claim that Jews attempt to exploit sympathies over the Holocaust as means to political power. This is a common argument among Polish nationalists who continue to view Jews as a threat to Polish national interests, despite the Jewish community in the country only numbering a few thousand.

Survey data demonstrates that indeed political anti-Semitism remains a prominent manifestation of anti-Semitism in Poland. In 1992, 38\% of Poles surveyed answered that they "would absolutely not vote for a presidential candidate of Jewish descent." This number only declined to 33\% by 2002 (Sulek, 2012: 431). In 1992, 18\% of Poles surveyed agreed with the statement "Poles had experienced more bad from Jews than 
good," and this number actually rose to $27 \%$ by 2002 (ibid). A 1999 survey showed that a majority (56\%) of Poles surveyed either responded "strongly agree" or "somewhat agree" with the statement "Now, as in the past, Jews exert too much influence on world events" (ibid: 436). As can be seen, regardless of the number of Jews actually residing in Poland, a substantial segment of the population of modern Poland continued to believe that Jews exert excessive influence on the country's political affairs even after the fall of communism. While there is little to no survey data available from the time period of communist occupation in Poland, it is likely that the anti-Semitic propaganda of the previous regimes continues to have a legacy in the country in terms of perceptions and distrust toward the Jewish community.

The subject of "coming to terms with the past" and revisiting the elements of Nazism that enabled the largest genocide in human history has remained controversial, but recent German and Polish governments have nonetheless made efforts to address the topic in a number of ways. The following chapters of this analysis will explore some of these measures and seek to evaluate how anti-Semitic attitudes and actions have been affected as a result.

\section{References}

Abramsky, Ch., Jachimczyk, M. and Polonsky, A. (eds) (1986). The Jews in Poland. Oxford: Blackwell.

Abramson, Henry (2013). Origins of Polish Jewry, jewishhistorylecture.org, 5 December: http://jewishhistorylectures.org/2013/12/05/origins-of-polish-jewrythis-week-in-jewish-history/, accessed on 20 October 2015.

Anti-Defamation League (2005). Attitudes Toward Jews in Twelve European Countries, May: http://www.adl.org/assets/pdf/israelinternational/european_attitudes_may_2005.pdf, accessed on 13 November 2015. 
Banas, J. (1979). The Scapegoats, the Exodus and the Remnants of Polish Jewry. London: Weidenfeld and Nicolson.

Ben-Sasson, H. (ed.) (1976). A History of the Jewish People. Cambridge, MA: Harvard UP.

Bernhard, Michael and Henryk Szlajfer (2004). From the Polish Underground. University Park, PA: University of Pennsylvania Press.

Black, E. (1987). Lucien Wolf and the Making of Poland: Paris 1919, Polin (2) Warsaw: Polonia.

Central Statistics Office (2011). National Survey 2011: Membership in Faith Communities, Warsaw: Republic of Poland.

Cichopek, Anna (2003). "The Cracow pogrom of August 1945: A Narrative Reconstruction". In Joshua D. Zimmerman. Contested Memories: Poles and Jews During the Holocaust and Its Aftermath. New Brunswick, NJ: Rutgers UP.

Cooper, Lee (2000). In the Shadow of the Polish Eagle. New York: Palgrave.

Davidowicz, L. (1993). The Holocaust and the Historian. Cambridge, MA: Harvard UP.

Dubnow, Sidney (2001). History of the Jews in Russia and Poland. Skokie: Varda.

Friedman, Jonathan (2012). Jewish Communities of Europe on the Eve of World War II. New York: Routledge.

Gallup (2004). "Religion in Europe: Trust Not Filling the Pews," September 21: http://www.gallup.com/poll/13117/religion-europe-trust-filling-pews.aspx, accessed on 13 November 2015.

Gross, Jan (1979). Polish Society Under Occupation: The Generalgouvernment 19391945. Princeton, NJ: Princeton UP.

Gutman, Y., Mendelsohn, E. and Shmeruk, Ch. (eds) (1989). The Jews of Poland Between Two World Wars. Hanover, NH: UP of New England.

Hundert, Gershon (1986). The Implications of Jewish Economic Activities for ChristianJewish Relations in the Polish Commonwealth, in Abramsky, Ch., Jachimczyk, M. and Polonsky, A. (eds), The Jews in Poland. Oxford; Blackwell.

Hundert, Gershon (2004). Jews in Poland-Lithuania in the Eighteenth Century: A Genealogy of Modernity. Berkeley: University of California Press. 
Jeske- Chojenski (1913). Poznaj Piastow. Warsaw: Panstowowy Instytut Wydawniczy.

Kent, Peter (2002). The Lonely Cold War of Pope Pius XII: The Roman Catholic Church and the Division of Europe. Montreal: McGill UP.

Korey, William (1995). Russian Antisemitism, Pamyat, and the Demonology of Zionism. London: Routledge.

Kunicki, Mikolaj (2012). Between the Brown and Red: Nationalism, Catholicism, and Communism in $20^{\text {th }}$ Century Poland. Athens, $\mathrm{OH}$ : Ohio UP.

Lerski, Halina (1996). Historical Dictionary of Poland. Santa Barbara: ABC-CLIO.

Lichten, J. (1986). Notes on the Assimilation and Acculturation of Jews in Poland 18631943, in Abramsky, Ch., Jachimczyk, M. and Polonsky, A. (eds) The Jews in Poland. Oxford: Blackwell.

Lukas, Richard (1986). The Forgotten Holocaust, the Poles Under German Occupation 1939-1944. Kentucky: UP of Kentucky.

Mahler, R. (1942). Anti-Semitism in Poland: Essays on anti-Semitism. New York: Conference on Jewish Relations.

Orlicki, J. (1983). Szkice z djiejow stosunkow polsko-zydowskich. Szczecin: Krajowa Agencja Wydawnicza.

Petrovsky-Shtern, (2009). Jews in the Russian Army 1827-1917 - Drafted into Modernity. Cambridge: Cambridge UP.

Poliakov, Leon (1974). The History of Anti-semitism. New York: The Vanguard Press.

Prekerowa, T. (1992). Zarys dziejow Zydow w Polsce w latach 1939-1945. Warsaw: Wydawnictwo Uniwersytetu Warszawskiego.

Ringelblum, E. (1985). Writings from the Warsaw Ghetto, Volume 1. Tel Aviv: Peretz.

Rudnicki, S. (1987). From 'Numerus Clausus' to 'Numerus Nullus', Polin 2. Oxford: Blackwell.

Sanford, George (2003). The Historical Dictionary of Poland. Oxford: Scarecrow.

Schultz, Joseph (1982). Judaism and the Gentile Faiths: Comparative Studies in Religion. Teaneck, NJ: Fairleigh Dickinson UP.

Smolar, A. (1987). “Jews as a Polish Problem,” Daedalus (Spring). 
Sulek, Antoni (2012). Ordinary Poles Look at the Jews, East European Politics and Society 26(2): 425-444.

Tomaszewski, I. and Werbowski, T. (1994). Zegota, The Rescue of Jews in Wartime Poland. Montreal: Price-Patterson.

Tomicki, J. (1982). Polska odrodzona. Warsaw: Wiedza Powszechna.

Weinryb, Bernard (1972). The Jews of Poland. Philadelphia: Jewish Publication Society.

Yivo Institute for Jewish Relations. (2010) Population and Migration: Population since World War I, http://www.yivoencyclopedia.org/article.aspx/Population_and_Migration, accessed 13 November 2015.

Zubrzycki, Genevieve (2006). The Crosses of Auschwitz: Nationalism and Religion in Post-Communist Poland. Chicago: University of Chicago Press. 


\section{CHAPTER IV}

\section{STATE RESPONSES IN GERMANY}

As the preceding chapters described, anti-Semitism has been a pervasive issue in Germany and Poland for centuries. Consequently, this issue has shaped many international perceptions about these countries and their people. This is certainly a negative perception that can undermine attempts at cooperation in many areas. As Germany and Poland emerged from the Cold War era, both countries sought to improve their international standing, and part of doing so required addressing the controversial aspects of each country's history, in particular anti-Semitism and the Holocaust.

"It is our [Germany's] national and civic duty to fight anti-Semitism" -German Chancellor Angela Merkel (Kirschbaum and John, 2014)

In the early post-Cold War period, the newly unified Germany faced numerous political, social, and economic challenges. Anti-Semitism, while commonly viewed as a social problem, can indeed affect a country's standing in other areas to the extent that perceptions of pervasive anti-Semitism among international actors undermines their cooperation and trust with regard to the country in question. Consequently, responding to accusations and the realities of anti-Semitism domestically became a concern for the German state. As has been mentioned, the two primary means of responding to this problem are legal measures and public diplomacy. In the German case, the legal measures are carried out exclusively by the state in a centralized fashion, as law is the domain of the state itself. Public diplomacy, on the other hand, tends to be far more pluralistic with numerous levels and agencies - both governmental and nongovernmental. 


\section{a. Germany's Legal Response}

Germany's legal response to anti-Semitism has tended to focus on three main areas: restrictions on hate speech and incitement (Volksverhetzung), adjustments to immigration law, and providing Judaism with legal status on par with major Christian denominations. Each of these areas of policy have been enacted or adjusted since reunification to either counter anti-Semitic attitudes or work toward reconciliation with the Jewish community. The following section will examine the legislation and policy actions taken in these areas.

\section{Hate Speech and Incitement}

Article V, Clause I of Germany's Basic Law (Grundgesetz) stipulates that: "Everyone has the right to freely express his opinions in speech, writing, and pictures" (Bundestag, 2016). However, Article V, Clause II states that: "These rights are limited by the provisions of the general laws, the provisions for the protection of young people and in the right of personal honor" (ibid.). Therefore, while German law does provide for the freedom of expression, the very next clause states that criminal law may indeed provide limitations on expression. In large part, these restrictions on expression have been enacted to prevent the rehabilitation of Nazism in Germany (Whine, 2008: 61).

Additionally, the restrictions have been aimed to prevent the incitement of hatred against Jews and other domestic minorities.

In the German Criminal Code (Strafgesetzbuch), there are two sections that apply directly to restrictions on anti-Semitic speech. Criminal Code Section 86 makes illegal the "Dissemination of Means of Propaganda of Unconstitutional Organizations." These restrictions apply to any party that has been declared unconstitutional by the Federal 
Constitutional Court of Germany or "propaganda, the contents of which are intended to further the aims of any National Socialist organization." The statute does, however, provide an exception when such propaganda is used "to promote art or science, research or teaching, reporting about current historical events or similar purposes" (German Ministry of Justice, 2016a). Section 86a applies similarly to the use of symbols of unconstitutional organizations. This may include "flags, insignia, uniforms, slogans, and forms of greeting." Penalties for such crimes may include up to three years imprisonment or a fine (German Ministry of Justice, 2016b).

The second section that addresses anti-Semitic and extremist speech in the German Criminal Code is Section 130 - Incitement to Hatred. Subsection 1 was introduced in 1960, while Subsections 3 and 4 were added as part of a revision in 1994. The first subsection of the statute, adopted in 1960, is written as follows:

(1) Whosoever, in a manner capable of disturbing the public peace:

1. incites hatred against a national, racial, religious group or a group defined by their ethnic origins, against segments of the population or individuals because of their belonging to one of the aforementioned groups or segments of the population or calls for violent or arbitrary measures against them; or

2. assaults the human dignity of others by insulting, maliciously maligning an aforementioned group, segments of the population or individuals because of their belonging to one of the aforementioned groups or segments of the population, or defaming segments of the population, shall be liable to imprisonment from three months to five years. (German Ministry of Justice, 2016c)

The third and fourth subsections of the statute apply directly to speech related to National Socialism, in particular the issue of Holocaust denial. These sections were added as part of the revision in 1994. The subsections are written as follows:

3. Whosoever publicly or in a meeting approves of, denies or downplays an act committed under the rule of National Socialism of the kind indicated in section 6 (1) of the Code of International Criminal Law, in a manner capable of disturbing the public peace shall be liable to imprisonment not exceeding five years or a fine. 
4. Whosoever publicly or in a meeting disturbs the public peace in a manner that violates the dignity of the victims by approving of, glorifying, or justifying National Socialist rule of arbitrary force shall be liable to imprisonment not exceeding three years or a fine. (German Ministry of Justice, 2016c)

It is worth noting that denying the Holocaust specifically was not criminalized in Germany until the revision of Section 130 in 1994. From the language of the statute, Germany offers two primary ways to prosecute those accused of Holocaust denial. Section 130 Subsection 3 makes Holocaust denial a crime as an offense against the public peace, while Subsection 4 considers Holocaust denial a form of libel against the victims (Swert, 2001: 164).

Enforcement of these laws, however, can only be carried out on German territory. As such, the Internet has now become the main source for neo-Nazi and other antiSemitic propaganda in the country. Sites are often set up in countries such as the United States or Denmark where the content is not prohibited (Bayzler, 2006: 6). Music has also become a popular means of disseminating anti-Semitic and racist messaging. Extremist groups and political parties, such as the NPD, have been known to distribute music and hold concerts targeting youth to increase support (Deutsche Welle, 2005). The German government has banned over one thousand songs deemed to be anti-Semitic or sympathetic to Nazism, but until recently it had been difficult to identify such music on the radio or at rallies and other events. But in 2013, German police developed an app, known as "Nazi Shazam," that allows authorities to recognize banned songs in just seconds via an "audio fingerprint" (Williams, 2013). Nonetheless, developments in technology and an inability to police activity emanating from outside the country present 
continuing challenges to German authorities in regard to enforcing the legal measures against anti-Semitism and Holocaust denial.

\section{German-Jewish Immigration Policy}

The German Basic Law (Grundgesetz) has had a provision since 1949 allowing for former German citizens and their descendants who were persecuted on political, racial, or religious grounds during the period of Nazi rule to apply to have their German citizenship reinstated. Article 116 paragraph 2 states:

Former German citizens who between January 30, 1933 and May 8, 1945 were deprived of their citizenship on political, racial, or religious grounds, and their descendants, shall on application have their citizenship restored. They shall be deemed never to have been deprived of their citizenship if they have established their domicile in Germany after May 8, 1945 and have not expressed a contrary intention. (German Foreign Ministry, 2016)

This provision may, of course, apply to a great number of Jews. In 1990, Germany's estimated Jewish population was about 28,000 - a small number compared to the preWorld War II population of 600,000 (Klusmeyer and Papademetriou, 2013: 189).

However, once the Soviet Union fell and the Cold War ended, there was a substantial population of Jews and their descendants from former Soviet states, many of who had German roots, who could now apply to have their German citizenship reinstated.

As a response, the German government under the Chancellorship of Helmut Kohl created a law in 1991 that allowed Jews from the former Soviet Union to immigrate with few restrictions. In crafting the policy, Kohl met with Heinz Galinski, an Auschwitz survivor who at the time was the chairman of the Central Council of Jews in Germany, and Kohl was sympathetic to the organization's calls to loosen immigration restrictions on former Soviet Jews as a humanitarian gesture and part of an effort to work toward 
reconciliation with the wider Jewish community (Der Spiegel, 1996). Both of these motivations are reflected in the law. Officially, most Jews emigrating from the former Soviet Union were classified by the German government as refugees - hence the humanitarian motivation. However, the loosening of immigration restrictions put Jews on a path to reclaim citizenship similar to that for ethnic Germans from former Soviet states - an equivalency drawn in part to work toward reconciliation (Klusmeyer and Papademetriou, 2013: 192). Despite calls from other government officials to limit the number of Jewish immigrants or impose entry criteria, such measures were rejected. Galinski strongly opposed the entry criteria proposals by arguing, "I, who was exposed to the selection process at Auschwitz, would never give way to [another] selection process" (Der Spiegel, 1996). Such arguments were indeed persuasive in shaping German-Jewish immigration policy in the 1990's.

Germany had a Jewish population of 28,000 in 1990 , but this number increased to approximately 88,000 by 2000 , according to the Central Council of Jews in Germany (Klusmeyer and Papademetriou, 2013: 190). These estimates are, however, based on how the definition of Jewishness is applied. Some estimates placed the population's number at roughly twice that of the Central Council (ibid.). From 1990 to 2000, Germany received more than 5,000 new Jewish immigrants each year. In order to help integrate these new populations, the state provided the recently arrived Jewish immigrants with a residence permit, the right to social assistance, housing, and language training (Der Spiegel, 1996). Consequently, the German state spent what equates to tens of millions of dollars per year on the program (Cohen, 2000). The reestablishment of Jewish communities in Germany was a goal of Jewish leaders such as Galinski, as well as some German politicians. This 
was indeed one reason given to justify the costs. Manfred Becker, a senior Berlin city official, stated that, "The reestablishment of a Jewish community is a kind of victory over the Nazis . . This is the point, even if such immigration costs money. We feel a sense of moral obligation on the German side" (ibid.).

However, not all were pleased with the program and a number of problems began to spark public discussions in the early 2000's. The three major challenges encountered by the arrival of post-Soviet Jewish immigrants can be classified as economic, linguistic, and social. Given their relatively low birth rate, post-Soviet Jewish immigrants had a higher median age than other immigrant groups. And although their education level tended to be higher than other groups, the Soviet degrees that many had attained often did not translate well to the German system. These factors tended to create difficulty for many post-Soviet Jews, as many found it difficult to find employment commensurate with their qualifications (Remennick, 2005: 35-36). Many post-Soviet Jews also lacked German language proficiency. This provided another hindrance to many in terms of employment opportunities but also led to a certain social alienation. Many post-Soviet Jews lacked regular social interaction with other Germans and instead concentrated social activities in their own networks. These factors often led to the creation of Jewish enclaves in German towns and cities (Klusmeyer and Papademetriou, 2013: 194-195). In essence, these economic, linguistic, and social challenges are all connected and often prevented many post-Soviet immigrants from fully integrating in the German economy and society.

Consequently, the law pertaining to Jewish immigrants to Germany was reformed in 2005. The changes to the law were implemented in order to counter some of the aforementioned problems with integration and the financial burden to the state in the 
form of welfare payments. Additionally, the Israeli government had been putting pressure on Germany to tighten its immigration laws with regard to Jewish immigration, so that more Jews would choose to settle in Israel. In 2004, for example, 20,000 Jews migrated to Germany whereas only 11,000 went to Israel (Bhatti, 2006). For these reasons, Germany enacted a few specific reforms. The changes to the law include requirements that new Jewish immigrants be under forty-five years old, financially self-sufficient prior to immigrating, and have a good working knowledge of German. These requirements are similar to those for persons wishing to enter Germany for purposes of family reunification or family-forming migration. Jewish immigrants must also show an invitation from a Jewish community in Germany (Klusemeyer and Papademetriou: 2013: 195).

The primary motivation behind opening Jewish immigration was simple: help restore domestic Jewish communities in order to normalize relations between Germans and Jews. And while the number of Jews in Germany has drastically increased since 1990, there is no consensus on whether or not the initiative has been successful in achieving the objectives that motivated the policy. Some scholars argue that by treating Jewish immigrants as a special category, this treatment has in effect set the group apart and hindered their overall integration into German society (Klusmeyer and Papademetriou: 2013, 196). Also, given the secularity and mixed heritage of many postSoviet Jews, many have questioned the authenticity of their Jewish identity (Remennick: $2005,50)$. So while it is clear that the loosening of immigration policy toward Jews in the early 1990's has greatly increased the number of Jews in Germany, debate remains as to whether or not the policy has actually improved German-Jewish relations. 


\section{The Legal Status of Judaism}

It is important to remember that while Germany has no state church and guarantees for the freedom of religion in Article IV of its Basic Law, the state does in fact play a role in providing support to otherwise independent religious institutions. However, religious institutions in Germany must be considered a legal unit in order to receive the recognition and support provided by the state in the form of tax benefits and subsidies. In other words, many religious institutions in Germany may engage in partnership with the state to attain certain benefits. Religious institutions may apply to be considered a "Public Law Corporation" (PLC) under German law, which allows the institution to select chaplains for select state institutions and levy a tithe (averaging about $9 \%$ of one's income tax) on its members and collected by the state (U.S. State Department, 2011).

For most of the post-WWII period, PLC status was granted to primarily Christian institutions, but in 2003 the German government took a special step to improve relations with the Jewish community. The German government and the domestic Jewish Community (the capital "C" signifies the distinguishing status of the German Community as a legal unit) entered into a state treaty (Staatsvertrag) in order to officially establish a relationship that would substantially raise the amount of money the Community would receive as a religious institutions and provide it legal status similar to that of the major Christian denominations (Peck, 2006: 6-7).

The treaty is known as the 2003 State Agreement on Cooperation and was agreed to by both the federal government and the Central Council of Jews in Germany. Germany's Jewish Community had for some time received financial help from the German federal and state governments, but the 2003 agreement provided an official, legal 
basis for such subsidies. In 2003, the agreement specified that the state would spend 3 billion Euros per year on the Jewish Community, and also raise funding in five years based on growth. Five years later, in 2008, the federal government increased funding by 2 billion Euros to a total of 5 billion (Deutsche Welle, 2008). Later, in 2011, the German government doubled subsidies to the Jewish Community to 10 billion Euros (Axelrod, 2011). The agreement emphasizes that the Central Council of Jews is to support all branches of Judaism with the funds provided. The Central Council reports annually to the federal government on the use of the funds. Additionally, the German federal government provides financial support to Jewish educational institutions, such as the Hochschule für Judische Studien in Heidelberg, the Rabbi Center at the University of Potsdam, and the Leo Baeck Institute. The federal government also covers $50 \%$ of the maintenance costs for Jewish cemeteries in the country (U.S. State Department, 2011).

Another emphasis of the 2003 Agreement was security for Jewish institutions and places of worship. The Agreement was officially signed on Holocaust Commemoration Day and a number of officials, including then Chancellor Gerhard Schröder, condemned all anti-Semitic acts and vowed to allocate significant resources to investigate such incidents and prosecute the perpetrators (Haaretz, 2003). Consequently, the state agreed to provide 24-hour police protection at synagogues and other Jewish institutions (U.S. State Department, 2011).

The 2003 State Agreement on Cooperation was a transformative step in the relations between the German state and its Jewish population. The Agreement legally put Judaism on a status similar to the major Christian denominations, and also emphasized a degree of partnership between the state and Jewish institutions. The increases in funding 
to the Jewish Community and related educational institutions may be a contributing factor in reviving modern Jewish life in the country. The emphasis placed on security and the investigation and prosecution of anti-Semitic acts by the federal government was also a significant step. The actual effectiveness of these efforts is however not yet entirely known. The following chapters will seek to address the likely effects that these policy responses have had over time.

\section{b. Germany's Public Diplomacy Response}

\section{The Impetus of Collective Guilt}

An important impetus behind Germany's response to anti-Semitism was the notion of collective guilt - a concept that can be applied both domestically and internationally. Psychoanalyst Carl Jung developed the concept of collective guilt (Kollectivschuld) in 1945 and used it to describe a feeling of shame among many Germans for the atrocities committed by their fellow countrymen (Olick and Perrin, 2010: 24-25). This feeling was perpetuated in part due to Allied propaganda that carried the slogan of "These Atrocities: Your Fault!" (Diese Schandtaten: Eure Schuld!). In this way, American and British occupation forces launched a campaign promoting shame and guilt - a strategy that likely left an impact not only on the German psyche, but also international perceptions of the country (ibid.: 109-117).

The notion of collective guilt became a defining aspect of the country's post-war, and indeed post-reunification, national identity. Mary Fulbrook argues that the impacts of collective guilt are amplified in the German case considering the country's political culture and affective bonds toward collective national identity (Fulbrook, 1999). Lars Rensmann expands upon this point by writing, "If a collective identity (i.e. belief in "the 
Fatherland") is highly valued, it may be an especially hard struggle to establish a selfcritical political discourse on the country's guilt" (Rensmann, 2004: 172). Attitudes and value systems emphasizing a binary friend-foe worldview, antipathy toward Jews, and an exclusionary view of German national superiority are present throughout contemporary German political history; however, as Rensmann goes on to argue "the post-War social recognition of German guilt and the development of a democratic identity thus had to rely on breaking with essential elements of the German tradition and its conventional narratives" (ibid.). Therefore, in order for Germany to change perceptions and repair the country's image abroad, the controversial domestic social and political issues relating to the Holocaust and anti-Semitism needed to be addressed publicly. It is for this reason that one cannot discount the connection between international perceptions and domestic engagement.

Given the extraordinary issues needing to be addressed in the German case, the country’s public diplomacy and its development differs from many other Western countries, such as the United States. While many countries indeed have controversial aspects to their history that shape perceptions among others, there are few, if any, events that mark a country's history as deeply and prominently as the Holocaust. Furthermore, the collective identity of many Germans is not only a state issue, but also a very personal and familial issue, given that many contemporary Germans are confronted with atrocities for which their own parents or grandparents may have been responsible. Konrad Brendler developed a typology for how Germans tend to deal with this notion of collective guilt and found a range of emotional responses from defensiveness to shame to ambivalence. Brendler found that $70 \%$ of Germans born after 1970 have problems wholeheartedly 
identifying with their German nationality, $65 \%$ express feelings of shame, and $41 \%$ display feelings of guilt (Brendler, 1994: 310-315). Some may even believe that the feelings of shame that they may experience are due to an undue burden for which Jewish revenge against Germans is responsible, thus perpetuating anti-Semitic tendencies. These factors and the lack of a unified conception of national identity made the development of a coherent and credible public diplomacy campaign increasingly difficult.

\section{Developing a Public Diplomacy Strategy}

A unique aspect of public diplomacy on issues such as anti-Semitism is the importance of domestic engagement in the process. Much of the literature on public diplomacy focuses on the concept of "promotion" and a country's efforts to emphasize the positive aspects of its culture, political values, and foreign policies. However, events such as genocide can overwhelm international perceptions about a particular country and thus need to be addressed publicly. In order for international messaging on such issues to be credible, these countries must first demonstrate domestic progress on these issues. As Peter van Ham describes, "branding has become essential to create value in the relationship between territories and individuals" (2008: 128). This relationship, however, is not merely between one territory and populations outside that territory, but also those within the territory. Peter van Ham goes on to argue that "place branding is also required to make a country's image work for its economy and its citizens" (2008: 128). Such a statement invokes the idea that place or nation branding inherently has a mechanism that is connected to not only external, but also internal, populations. This element of credibility is an important link between the domestic and international spheres. The case of Germany and its public diplomacy efforts with regard to anti-Semitism and the Jewish 
community are a prime example of this linkage. This section will address Germany's public diplomacy approach on this issue, the context and motivations guiding the approach, as well as discuss some of the initiatives that have been implemented. Although Germany and its various regimes have long placed an emphasis on the cultural and educational aspects of foreign policy, the German conception of public diplomacy has shifted greatly since the end of the Cold War. The totalitarian Nazi and GDR regimes, while active in promoting their values and cultures internationally, allowed little to no room for pluralistic ideas or critical self-reflection - elements central to the credibility of a state's messages (Auer and Srugies, 2013: 21-23). However, once these governments ceased to exist, so did their goals and messaging. The reunification of Germany in 1990 strengthened the country's place in the world and consequently thrust upon it greater responsibility for cooperation internationally, and especially within Europe.

As a response to Germany's newfound standing and inherent responsibilities, the German Federal Foreign Office (Auswärtiges Amt) developed a strategic document in 1999 called the "Konzeption 2000," which sought to outline the primary goals and principles of Germany's public diplomacy efforts. The Konzeption 2000 focused on four main areas: 1) fostering German foreign cultural and educational political efforts abroad; 2) establishing and maintaining a positive modern image of Germany abroad; 3 ) furthering the European integration; 4) preventing conflicts by setting up a dialogue on values (Konzeption 2000,1999). One could argue that the problem of anti-Semitism, and outsiders' perceptions of the problem in Germany, undermined Germany's goals in each of these four areas, and therefore became critical to address publicly. 
The Konzeption 2000 was a crucially important document in the formation of Germany's public diplomacy strategy and laid the groundwork for a number of programs that have become influential in addressing anti-Semitism. Notably, much of the document focuses on youth education in collaboration with other countries to inform young people about the crimes and atrocities of the past in order to prevent future violence. One initiative that has been central to this effort has been the Task Force for International Cooperation on Holocaust Education, Remembrance and Research. The Task Force began in 1998 in cooperation with Sweden, the United States, the United Kingdom, Israel, and Germany. Activities that the Task Force has undertaken include informational exchanges among students, developing textbooks, and educating teachers on how to discuss the topic of anti-Semitism to students (Konzeption 2000, 1999). This initiative is done in conjunction with other youth exchange, sports, and cultural education programs. The Task Force and its related activities are a prime example of the connections between the domestic and international realms in Germany's public diplomacy, as well as the efforts to counter anti-Semitism and cope with issues of the past.

One must note that in order to develop an effective, credible public diplomacy strategy, Germany needed to go beyond simply public relations and promotional campaigns. An important lesson that policymakers learned from the experiences of the GDR was that honesty and critical self-reflection are necessary ingredients for fostering trust with international audiences (Auer and Srugies, 2013: 22-23). Before a country can effectively and credibly promote itself, its leaders need to have a clear understanding of what is to be represented and how international audiences will most likely respond. Therefore, unified Germany's public diplomacy campaign required the addressing of 
domestic concerns in order to make international messages credible and salient. As Claudia Auer and Alice Srugies write, "Critical self-reflection also includes reprocessing Germany's past as a precondition for its external representation ... Against the backdrop of a growing interconnection of the national and international spheres, this strategy must also apply to domestic audiences" (Auer and Srugies, 2013: 26). So while many tend to view public diplomacy as simply a smaller part of a country's larger foreign policy, public diplomacy is indeed closely connected to domestic affairs as well. In order to develop credible messaging internationally, countries must have a certain consistency between their domestic affairs and the messages they intend to distribute abroad. In other words, the motivations behind the German government's responses to anti-Semitism are related to both the country's desire to ensure domestic tranquility and promote a positive image abroad.

\section{Three Layers of Public Diplomacy Actors}

It is important to note that unlike with legal measures taken against anti-Semitism, public diplomacy strategy in the German case is not necessarily centralized within the state. There are a multitude of actors - some governmental, some non-governmental. The state in many instances, however, does indeed play an important role in agenda setting and facilitation. Claudia Auer and Alice Srugies have developed a typology to help explain the various actors in German public diplomacy, and this typology classifies actors as either macro, meso, or micro (Auer and Srugies, 2013: 12-15). This typology is displayed in Table 3.1 This section will present this typology and provide examples of each from the German case. 
Table 3.1: Actors of Public Diplomacy

\begin{tabular}{|c|c|c|c|}
\hline Layer & Type & Manifestation & $\begin{array}{c}\text { Influential } \\
\text { structure }\end{array}$ \\
\hline Micro & individual actor & $\begin{array}{l}\text { role keeper (e.g. citizen, } \\
\text { organizational role) }\end{array}$ & $\begin{array}{l}\text { constellation } \\
\text { of actor }\end{array}$ \\
\hline \multirow{5}{*}{ Meso } & \multirow{5}{*}{ complex actor } & $\begin{array}{l}\text { economic/political solidarity } \\
\text { groups/organizations } \\
\text { (e.g. political parties, }\end{array}$ & \multirow{5}{*}{$\begin{array}{l}\text { institutional } \\
\text { structures }\end{array}$} \\
\hline & & $\begin{array}{l}\text { organizations oriented towards } \\
\text { the common good } \\
\text { (e.g. groups, society, clubs) }\end{array}$ & \\
\hline & & $\begin{array}{l}\text { interest organizations } \\
\text { (e.g. social and protest } \\
\text { movements, NGOs) }\end{array}$ & \\
\hline & & $\begin{array}{c}\text { public organizations } \\
\text { (e.g. elected councils, public } \\
\text { administration) }\end{array}$ & \\
\hline & & $\begin{array}{l}\text { economic single organization/ } \\
\text { company }\end{array}$ & \\
\hline \multirow[t]{2}{*}{ Macro } & \multicolumn{2}{|c|}{ social subsystem as actor (e.g. politics) } & $\begin{array}{c}\text { subsystemic } \\
\text { orientation } \\
\text { horizon }\end{array}$ \\
\hline & \multicolumn{3}{|c|}{ nation as actor } \\
\hline
\end{tabular}

Source: Auer and Srugies, 2013: 15

Macro: The state itself is considered a macro-level actor given its large amount of resources, funding, and influence. But one must remember that the "state" as a public diplomacy actor is not inherently unified, but rather is an aggregation of agencies that may each undertake their own communication efforts. Macro-level actors operate in various sectors of society from military to education to economy. Nonetheless, there are generally certain agencies that take a leading role on certain issues, and with regard to 
anti-Semitism in Germany the two leading agencies tend to be the Federal Office for Protection of the Constitution (Bundesamt für Verfassungsschutz - BfV) and Federal Foreign Office (Auswärtiges Amt - AA). The Ministry of the Interior oversees the BfV and its primary objective is to gather information on domestic threats concerning the country's democratic order - oftentimes extremist groups. The AA is responsible for carrying out Germany's foreign policies, including its relationship with the European Union. Consequently, the structure of Germany's public diplomacy strategy emphasizes this connection between the domestic and international realms. Of course, there are other agencies involved on the macro, governmental level; however, such agencies are often in coordination with, led by, or heavily influenced by the agenda's set forth by the BfV or AA.

Meso: The next, and most complex, level of actors is the meso level. This level consists of a number of societal groups that focus on particular aspects of society, such as politics, culture, or economics (Leonard et al., 2012: 8). This includes most NGOs, social groups or clubs, local councils, and even political parties. These organizations and the relationships they forge can have important impacts on the public diplomacy and representations of a country both abroad and domestically. Of course, the goals of these organizations may differ both generally and on particular issues, which demonstrates the decentralized nature of public diplomacy and in particular the German case. Some of the important meso level organizations in Germany include the Coordination Forum for Countering Anti-Semitism, Friedrich Ebert Foundation, Konrad Adenauer Foundation, Central Council of Jews in Germany, the Jewish Community of Berlin (Jüdische Gemeinde zu Berlin), and even the major German political parties (such as the Social 
Democratic Party (SPD) and Christian Democratic Union (CDU)). One must note, however, that there are numerous other organizations that may play a role at this level, many of which have relationships with organizations abroad that often participate in financing or the dissemination of messages.

Micro: The micro level primarily refers to individuals who may lead public opinion or engage in public diplomacy efforts in some way. These may be public figures, such as politicians, artists, or scholars, or even average citizens who exchange ideas with others. In this way, individuals shall be viewed not only as recipients of public diplomacy messages, but also as communicators themselves. Individuals' actions may be influenced by actors at the macro or meso levels of public diplomacy, but individuals often do act autonomously, which further demonstrates the decentralized nature of public diplomacy a characteristic evident in the German case. Individuals can engage in public diplomacy through such means as exchange programs, artistic representations, speeches, or any other means intended to represent one's country in some way. Given advances in technology and the increased ability of individuals to communicate internationally, individuals are becoming increasingly important in the exercise of a state's public diplomacy.

\section{Development of Germany's Public Diplomacy Campaign}

Initiating public conversations about national identity and complex issues such as collective guilt and anti-Semitism are indeed lengthy and controversial processes, and this has certainly been the case with Germany. The German word for this process is Vergangenheitsbewältigung (overcoming the past). The theme of Vergangenheitsbewältigung had been prevalent in German culture and discourse for 
decades, as evidenced by the popularity of the works of such authors as Günther Grass, Siegfried Lenz, and the creation of various museums and monuments dedicated to the victims of the Holocaust and World War II. In 1990, however, the German state recognized that unification brought along opportunities for Germany to advance its capabilities and leadership role in Europe. Many in German leadership at the time had desires for greater European integration and for Germany to be viewed as a stable element in the West (Katzenstein, 1997: 4). But one of the major obstacles to achieving these goals was the long-lasting damage done to the country's moral authority by the Nazi regime, and particularly the anti-Semitic violence that many tend to associate with the country and its past. Consequently, the unified German government began to put institutions and messaging in place that not only represents the country abroad, but also facilitates domestic engagement in the process.

Beginning in 1990, Germany's Federal Foreign Office (AA) assumed the role of identifying global problems and developing the framework through which Germany's public diplomacy operates. In this way, the AA has acted as a leader in prioritizing the issues upon which the country's messaging and other public diplomacy efforts are based (Ritterberger and Wagner, 2001: 16-17). And since 1990, one of the AA's primary goals has been "consolidation of the unity of the German Kulturnation" (Karten, 2008: 163). This statement means that the AA wants Germany to be portrayed as a democratic, trustworthy nation that is defined by its culture. This goal is driven by a desire to separate the contemporary, peaceful state to that of the aggressive, violent Nazi past. Consequently, this message draws greater attention to Germany's domestic environment 
and in some ways invites outsiders to observe closely in what ways the country has progressed beyond the negative aspects of its history.

This desire to demonstrate the country's progress has penetrated numerous areas of its public diplomacy. While the AA was indeed the leading agency in facilitating and spawning Germany's early public diplomacy campaign, today's actors are eager to avoid any impressions of replicating the centralized nature of past propaganda ministries (Auer and Srugies, 2013: 25). Consequently, Germany adopted what is known as a "network oriented” approach to public diplomacy early in its campaign (Bagger, 2013: 47-48). Under this approach, several federal ministries finance and coordinate public diplomacy efforts, but the majority of activities are carried out by intermediary organizations that operate largely autonomously (Auer and Srugies, 2013: 25). This type of approach allows these intermediary organizations to specialize in certain issues and develop domestic and international relationships with other organizations to spread messaging and develop solutions to problems of concern. Notably, the German public diplomacy approach tends to take advantage of the relatively well-developed German civil society organizations in order to amplify messaging both domestically and internationally.

\section{Major Civil Society Organizations}

There are a number of non-governmental organizations that have been instrumental in forging relationships and delivering the messaging of Germany's public diplomacy campaign against anti-Semitism. One of the organizations most targeted on this particular goal is the Amadeu Antonio Foundation (AAS), which was established in 1998 and named after one of reunified Germany's first victims of right-wing extremist violence. The AAS operates under the patronage of Wolfgang Thierse, a former president 
of the Bundestag, and has carried out more than 770 projects and initiatives aimed at countering anti-Semitism and racism (Amadeu Antonio Foundation, 2015). The AAS maintains a heavy online presence and tends to focus on developing and implementing strategies to counter extremist violence and rhetoric on the local level.

AAS's online initiatives often are collaborative efforts with media and other civil society organizations with each targeting anti-Semitism and racism from different perspectives. The AAS operates an online platform called "Mut gegen rechte Gewalt" (Courage against right-wing violence) in partnership with Stern magazine, which chronicles trends in anti-Semitic and racist violence and proposes strategies to prevent future incidents (Mut gegen rechte Gewalt, 2016). Similarly, the AAS operates the website "Netz gegen Nazis" (Net Against Nazis) in partnership with Die Zeit newspaper that focuses on reporting the online activities of right-wing extremist groups online and contains a database of known extremist group activities in Germany. The staff of this particular website specializes in consulting on how to deal with extremist group members online and in other settings such as the workplace (Netz Gegen Nazis, 2016). As technology develops and extremist groups continually adapt to new technology in their activities, the AAS has worked to develop countermeasures online to oppose the spread of extremist ideology.

Additionally, the AAS has been active at the grassroots level by providing communities with financial, administrative, and expertise support to counter anti-Semitic and other extremist influences. The AAS is active in opposing Neo-Nazi groups in local, state, and national elections through a program called "Kein Ort für Neo-Nazis" (No place for Neo-Nazis). This initiative works to prevent the election of anti-Semitic and 
racist candidates to elected office. In places where extremist and Neo-Nazi politicians already hold office, the AAS launched the program "Region in Aktion" (Region in Action), which is aimed to strengthen civil society opposition to discriminatory policy proposals. This program has been most active in parts of the former East Germany where far-right parties have found greater success. The AAS also supports numerous youth initiatives that promote youth cultures opposed to anti-Semitism, intolerance, and racism. The goal of these initiatives is to weaken the recruitment prospects of Neo-Nazi and other extremist organizations. Finally, the AAS operates a program for victims of racist and anti-Semitic violence called the "Opferfund Cura" (Victims' Fund Cura). This initiative provides direct support to the victims' of extremist violence, informs others about the problems they face, and offers consultations about the best methods for support (Amadeu Antonio Stiftung, 2016). Through these various initiatives, the Amadeu Antonio Foundation has become one of the most active civil society organizations in terms of responding to the problem of anti-Semitism in Germany.

Another organization that carries out similar work against anti-Semitism and extremism is the Center for Democratic Culture (ZDK), which was founded in 1997 with a particular focus on countering extremism in the "new" German states from the former GDR. While the ZDK carries out similar initiatives to the AAS, such as outreach to media, academia, regional governments, and businesses to counter extremist influences, the tactics and emphases of the ZDK tend to differ in some important ways. The ZDK is known for employing "guerilla tactics" in terms of confronting extremist group members and their efforts to convince members to leave their particular movements. A prime example of such tactics came in 2012 when the ZDK distributed t-shirts with the words 
"Hardcore Rebels" at a rock concert known to be popular with extremist group followers. After the first wash, the writing on the shirts would disappear and be replaced with the words "What your shirt did, you can also. We will help you solve right-wing extremism" (Mayer, 2015). The ZDF also organizes a number of marches, and counterdemonstrations to those of far-right and Neo-Nazi groups (Zentrum Demokratische Kultur, 2016).

Perhaps the most noteworthy of the ZDF's activities is its involvement in the Exit-Deutschland program, which provides a means for former far-right and Neo-Nazi members to leave their respective organizations and lifestyles. In fact, one of the cofounders of the program, Ingo Hasselbach, was a former Neo-Nazi activist himself. ExitDeutschland is largely financed by the Federal Ministry of Family Affairs, but takes donations from a number of sources (Exit-Deutschland, 2016a). The program helps members of extremist groups, who have a desire to leave, with counseling, education, and in some instances security is even provided to those members who have been threatened. The goal of the program is to provide former extremists with personal skills and insight to re-orientate their personal relationships and daily lifestyles. In 2013, the German Cabinet made the decision to promote the program long-term and indeed has agreed to provide support through at least 2019 (Ostermann, 2013). From May 2000 to January 2016, Exit-Deutschland claims to have helped over 500 former extremists overcome their ideologies and leave their organizations with a recidivism rate of only $3 \%$ (ExitDeutschland, 2016b).

Beyond merely combatting far right and other anti-Semitic groups, German civil society groups, at times in conjunction with governmental agencies, have also been involved in emphasizing the importance of the country's Jewish community and culture. 
Many of these initiatives are centered in Berlin, which has an estimated Jewish population of 40,000 (Associated Press, 2014). One of the most prominent examples of these efforts has been the restoration and reopening of the Jewish Museum of Berlin. The first Jewish Museum of Berlin was founded in 1933, but was closed by the Nazis in 1938 . In August 2001, the Bundestag passed a law establishing a Jewish Museum Berlin Foundation, which is an official federal foundation designated to research and describe Jewish life in Berlin and Germany and to create a meeting place for Jews and those interested in Jewish life (Jewish Museum Berlin, 2016a). The museum officially opened in September 2001 with a permanent exhibition entitled "Two Millennia of German Jewish History" and seeks to present Germany through the eyes of the country's Jewish minority. The Academy of the Jewish Museum Berlin was established in 2012 to serve as a forum for discussion in the community on issues of pluralism and the rights of minority populations in Germany (Jewish Museum Berlin 2016b). The museum also works closely with the Leo Baeck Institute and its branches in New York, London, and Jerusalem to promote education on Jewish life in Germany (Foundation of the Jewish Museum Berlin, 2010).

Another organization that has been heavily involved in engaging German Jews with others around the world has been the Jewish Community of Berlin. The Jewish Community of Berlin was established in 1671, but has recently become an active organization in carrying out Germany's public diplomacy messaging with both governmental and corporate partners sponsoring these efforts. One of the more prominent initiatives has been the Days of Jewish Culture, which began as a cultural festival in Berlin in 1987 but has since spread internationally. Each year, the festivals are dedicated 
to a different theme and feature theatrical performances, readings, discussions, exhibitions, and concerts from German and international performers. Outside Berlin, festivals have also been held in international cities, such as Vienna, New York, Paris, Odessa, and Tel Aviv (Jewish Community of Berlin, 2016a). Sponsors of the event include the Israeli embassy, Mercedes Benz, the Berliner Morgenpost, and Landau Media among others (Jewish Community of Berlin, 2012).

Another important function of the Jewish Community of Berlin is the group's Integration Office, which was founded in 1998 and seeks to provide support to immigrated Jews in Germany. Approximately two-thirds of Jews in Berlin are from the former Soviet Union, and the Integration Office provides a number of services to help these individuals adjust to living in Germany, such as job training, socio-political and economic education as well as language training. These initiatives are intended to not only help German Jews obtain employment opportunities, but also take part in social activities and increase communication with other Germans. Additionally, the office provides counseling to those who have difficulty acclimating to life in Germany. The Integration Office provides counseling services to approximately 1,600 German Jews each year in an effort to make the domestic Jewish community feel more comfortable living in Germany (Jewish Community of Berlin, 2016b).

\section{Conclusion}

The German approach to countering anti-Semitism is certainly multifaceted involving numerous organizations - both governmental and non-governmental. The legal measures enacted are indeed within the domain of the state. The German government has reformed laws regarding hate speech and incitement, immigration, and has engaged in a 
legal partnership with the domestic Jewish Community to aid in its revitalization.

Additionally, Germany has taken a unique approach to public diplomacy by emphasizing self-critical reflection and a decentralized structure to demonstrate the country's progress on the issue of anti-Semitism. To be sure, the state has played a role in facilitating and financing many of the contemporary efforts, but non-governmental institutions often specialize in particular areas and establish relationships with other groups inside and outside of the country. Having such a domestic focus in public diplomacy is rare, but anti-Semitism is one issue where this has nonetheless been the case. The following part of this chapter will examine Poland's approach to these issues, and the final chapters will analyze the effectiveness of the efforts in both countries.

\section{References}

Amadeu Antonio Stiftung (2015). Übersicht der geförderten Projekte and unterstützten Personen 2015, http://www.amadeu-antonio-stiftung.de/projektfoerderung/bilanz2015/, accessed on 6 February 2016.

Amadeu Antonio Stiftung (2016). Campaigns, http://www.amadeu-antonio-stiftung.de/eng/we-are-active/campaigns/, accessed on 7 February 2016.

Associated Press (2014). "Epi-Center of Holocaust Now Fastest-Growing Jewish Community," Haaretz, 8 April: http://www.haaretz.com/jewish/news/1.584490, accessed on 13 February 2016.

Auer, Claudia and Alice Srugies (2013). Public Diplomacy in Germany, Perspectives on Public Diplomacy 5: 1-56.

Axelrod, Toby (2011). Germany Doubling Its Funding to Jewish Community, Jewish Telegraphic Agency, 28 November: http://www.jta.org/2011/11/28/newsopinion/world/germany-doubling-its-funding-to-jewish-community, accessed on 1 April 2016.

Bagger, Thomas (2013). "Netzwerkpolitik.” Internationale Politik, 8 January. 
Bayzler, Michael (2006). Holocaust Denial Laws and Other Legislation Criminalizing Promotion of Nazism, Yad Vashem Institute for Holocaust Studies:

https://www.yadvashem.org/yv/en/holocaust/insights/pdf/bazyler.pdf, accessed on 20 March 2016.

Bhatti, Jabeen (2006). Germany's Jew Mull Future as Immigration Drops, Deutsche Welle, 27 November: http://www.dw.com/en/germanys-jews-mull-future-asimmigration-drops/a-2247891, accessed on 24 March 2016.

Brendler, Konrad (1994). Die Holocaustrezeption der Enkelgeneration im Spannungsfeld von Abwehr und Traumatasierung, Jahrbuch für Antisemitismusforschung 3: 303-340.

Bundestag (2016). Grundgesetz, https://www.bundestag.de/grundgesetz, accessed on 12 March 2016.

Cohen, Roger (2000). Former Soviet Jews Find Uneasy Peace in Germany, New York Times, 6 August: http://www.nytimes.com/2000/08/06/world/former-soviet-jewsfind-uneasy-peace-in-germany.html?pagewanted=all, accessed on 25 March 2016.

Cohen, Y. and Kogan, I. (2005). Jewish Immigration from the Former Soviet Union to Germany and Israel in the 1990's, The Leo Baeck Institute Yearbook, 50(1): 249265.

Der Spiegel (1996). Einwanderer: So Leise wie Möglich, 27 May: http://www.spiegel.de/spiegel/print/d-8928367.html, accessed on 25 March 2016.

Deutsche Welle (2005). Neo-Nazis Spreading Message and Recruiting Through Music, 12 December: http://www.dw-world.de/dw/article/0,2144,1827739,00.html, accessed on 20 March 2016.

Deutsche Welle (2008). Germany Boosts Financial Support for Jewish Community, 25 September: http:/www.dw.com/en/germany-boosts-financial-support-for-jewishcommunity/a-3669667, accessed on 1 April 2016.

Exit-Deutschland (2016a). Über uns, http://www.exit-deutschland.de/exit/?c=ueberuns, accessed on 7 February 2016.

Exit-Deutschland (2016b). EXIT-Germany: We Provide Ways Out of Extremism, http://www.exit-deutschland.de/english/, accessed on 7 February 2016.

Foundation of the Jewish Museum Berlin (2010). Highlights from the Jewish Museum Berlin. Berlin: Nicolari-Verlag. 
Fulbrook, Mary (1999). German National Identity After the Holocaust. Cambridge, UK: Polity.

German Foreign Ministry (2016). Restored Citizenship, http://www.germany.info/Vertretung/usa/en/05_Legal/02_Directory_Services/ 02 _Citizenship/_Restored.html, accessed on 25 March 2016.

German Ministry of Justice (2016a). Verbreiten von Propagandamitteln verfassungswidriger Organisationen, http://www.gesetze-iminternet.de/stgb/_86a.html, accessed on 13 March 2016.

German Ministry of Justice (2016b). Verwenden von Kennzeichen verfassungswidriger Organisationen, http://www.gesetze-im-internet.de/stgb/_86.html, accessed on 13 March 2016.

German Ministry of Justice (2016c). Volksverhetzung, http://www.gesetze-iminternet.de/stgb/_130.html, accessed on 13 March 2016.

Haaretz (2003). Germany's Jews Sign Historic Pact; France Torn by Talk of AntiSemitism, 28 January: http://www.haaretz.com/germany-s-jews-sign-historicpact-france-torn-by-talk-of-anti-semitism-1.20905, accessed on 1 April 2016.

Jewish Community of Berlin (2012). Jüdische Kulturtage 2012, http://www.jgberlin.org/fileadmin/redaktion/downloads/JKT_2012_Programmheft.pdf, accessed on 16 February 2016.

Jewish Community of Berlin (2016a). Days of Jewish Culture, http://www.jg-berlin.org/en/institutions/culture/juedische-kulturtage.html, accessed on 16 February 2016.

Jewish Community of Berlin (2016b). Integration, http://www.jg-berlin.org/en/institutions/integration.html, accessed on 16 February 2016.

Jewish Museum Berlin (2016a). Foundation Regulations, http://www.jmberlin.de/main/EN/04-About-The-Museum/03-Organization/03foundation-regulations.php, accessed on 13 February 2016.

Jewish Museum Berlin (2016b). The W. Michael Blumenthal Academy of the Jewish Museum Berlin, http://www.jmberlin.de/main/EN/03b-Academy/00academy.php, accessed on 13 February 2016. 
Karten, Britt Inga (2008). Staatliche Imagearbeit: Die Public Diplomacy des Auswärtigen Amtes. In Die amerikanische Regierung gegen die Weltöffentlichkeit? Theoretische und empirische Analysen der Public Diplomacy zum Irakkrieg (eds.) Thomas Jäger and Henrike Viehrig, 163-90. Wiesbaden: VS Verlag für Sozialwissenschaften.

Katzenstein, Peter (1997). United Germany in an Integrating Europe, in Tamed Power: Germany in Europe (ed.) Peter Katzenstein. Ithaca: Cornell UP.

Kirschbaum, Erik and Bethan John (2014). At a Landmark Berlin Rally, Merkel Vows to Fight Anti-Semitism, Reuters, 14 September:

http://www.reuters.com/article/us-germany-jews-merkelidUSKBN0H90MK20140914, accessed on 5 February, 2016.

Klusmeyer, Douglas and Demetrios Papademetriou (2013). Immigration Policy in the Federal Republic of Germany. New York: Berghahn.

Konzeption 2000 (1999). Auswärtige Kulturpolitik - Konzeption 2000, Auswärtiges Amt - German Federal Foreign Office, from http://www.ifa.de/fileadmin/pdf/aa/akbp_konzeption2000.pdf, accessed 18 January 2016.

Leonard, Mark, Catherine Stead, and Conrad Smewing (2002). Public Diplomacy. London: The Public Diplomacy Centre.

Mayer, Ayla (2015). Ein Euro pro Hassposting: Rassisten sammeln unfreiwillig für Flüchtlinge, Der Spiegel, 23 October: http:/www.spiegel.de/netzwelt/web/hasshilft-fuer-jedes-facebook-hassposting-ein-euro-fuer-fluechtlinge-a-1059304.html, accessed on 7 February 2016.

Mut gegen rechte Gewalt (2016). Über uns, http://www.mut-gegen-rechtegewalt.de/, accessed on 6 February 2016.

Netz Gegen Nazis (2016). Wissen, http://www.netz-gegen-nazis.de/, accessed on 6 February 2016.

Olick, Jeffrey and Andrew Perrin (2010). Guilt and Defense, Cambridge, MA: Harvard University Press.

Ostermann, Dietmar (2013). 'Exit' Dropout Initiative Can Continue, Badische Zeitung, 22 March: http://www.badische-zeitung.de/deutschland-1/aussteiger-initiativeexit-kann-weitermachen--70249792.html, accessed on 7 February 2016.

Peck, Jeffrey (2006). Being Jewish in the New Germany, New Brinswick, NJ: Rutgers UP. 
Remennick, L (2005). Idealists Headed to Israel, Pragmatics Chose Europe: Identity Dilemmas and Social Incorporation among Former Soviet Jews Who Immigrated to Germany, Immigrants and Minorities 23(1): 30-58.

Rensmann, Lars (2004). Collective Guilt, National Identity, and Political Processes in Contemporary Germany, In: Branscombe, Nyla and Bertjan Doosje (eds.) Collective Guilt: International Perspectives. Cambridge, UK: Cambridge UP.

Rittberger, Volker, and Wolfgang Wagner (2001). German Foreign Policy Since Unification - Theories Meet Reality. In Panel: Zehn Jahre Neue Deutsche Außenpolitik: Eine Bilanz. http://www.deutscheaussenpolitik.de/resources/conferences/rittberger.pdf.

Swert, Bert (2001). Denying Shoah, In Personal Autonomy, The Private Sphere and Criminal Law: A Comparative Study (eds.) Peter Alldridge and Chrisje Brants, Portland, OR: Hart.

U.S. State Department (2011). Country Reports on Human Rights Practices - Germany, 8 April: http://www.state.gov/documents/organization/171696.pdf, accessed on 1 April 2016.

van Ham, Peter. (2008) Place Branding: The State of the Art, Annals of the American Academy of Political and Social Science 616: 126-149.

Werz, Nicholaus. External Cultural Policy: Continuity or Change. Aussenpolitik 42, no. 3 (1992): 246-55.

Whine, Michael (2008). Expanding Holocaust Denial and Legislation Against It, Jewish Political Studies Review 20(1): 57-77.

Williams, Rob (2013). 'Nazi Shazam': German Authorities Plan to Use App to Banned Neo-Nazi Music at Rallies, The Independent, 3 December: http://www.independent.co.uk/news/world/europe/nazi-shazam-germanauthorities-plan-to-use-app-to-identify-banned-neo-nazi-music-at-rallies8980919.htmlw, accessed on 20 March 2016.

Zentrum Demokratische Kultur (2016). Startseite, http://zentrum-demokratische-kultur.de/start/, accessed on 7 February 2016. 


\section{CHAPTER V}

\section{STATE RESPONSES IN POLAND}

Since the end of the Cold War, Poland has sought to elevate its place in the international community, but faced serious challenges to gain visibility and address perceptions about its controversial national history. Foremost among those controversial international perceptions was Poland's historical relationship with the Jewish faith. As the primary location of the Holocaust, Poland has been perceived by many to be essentially a Jewish graveyard (Ociepka and Ryniejska, 2005: 6). This perception has presented a challenge for Poland in terms of establishing itself as an attractive and credible international partner.

In order to counter these negative perceptions and gain international credibility, Poland has recently taken steps to demonstrate progress on the issue of anti-Semitism. Similar to the German case, Poland has employed both legal and public diplomacy measures to counter the problem. Poland has, like Germany, adopted legislation that penalizes certain anti-Semitic speech; however, the Polish legal response is less focused on the issues of Jewish immigration and the legal status of the religion. The Polish government has nonetheless taken steps to not only address current manifestations of anti-Semitism, but also the historical harm that anti-Semitism has caused the country's Jewish community. In terms of the public diplomacy response, Poland's approach tends to focus on building partnerships between governmental agencies and Jewish communities - both foreign and domestic. These efforts have in part been motivated by a desire to preserve, remember, and perhaps even revitalize Jewish life within the country. 


\section{a. Poland's Legal Response}

Like in the German case, Poland has adopted legal measures to counter antiSemitic behavior, and has indeed done so on many of the same issues as the German government. Poland has passed legislation restricting certain speech on issues such as Holocaust denial, allowed for the repatriation of Poles from the former Soviet Union (many of whom were Jews), and provided support for the primary registered Jewish organization in the country. One must note, however, that Poland's response to antiSemitism has developed differently from that in the German case. A primary difference between the two cases is that while the German response was developed in the midst of reunifying two countries (with West Germany already having some measures in place), Poland was forced to overhaul its entire political and legal system after the fall of communism. This dynamic presented additional challenges in the Polish case, and is a likely reason as to why the Polish response to anti-Semitism has in some ways taken longer to develop than in the German case. Nonetheless, both countries have indeed made countering anti-Semitism a priority in recent times, and while these approaches may differ in terms of their development and timeline, there are indeed certain areas where the approaches overlap and even parallel one another.

\section{Hate Speech and Incitement}

As in Germany, the Polish Constitution, adopted in 1997, has provisions intended to protect the right of free expression. Article 14 stipulates that "The Republic of Poland shall ensure freedom of the press and other means of social communication." Similarly, Article 25, Clause 2 stipulates that "Public authorities in the Republic of Poland shall be impartial in matters of personal conviction, whether religious or philosophical, or in 
relation to outlooks on life, and shall ensure their freedom of expression within public life" (Polish Sejm, 2016). These provisions demonstrate the extent to which free expression is codified in contemporary Poland.

However, these rights of free expression do, as is the case in many countries, have limitations. The Polish Penal Code (Kodeks Karny), adopted in 1997, contains provisions regulating hate speech and incitement against social groups on the basis of nationality, ethnicity, race, and religion. There are indeed three articles in the Penal Code that apply to crimes associated with anti-Semitism. Article 196 states that:

Whoever offends the religious feelings of other persons by outraging in public an object of religious worship or a place dedicated to the public celebration of religious rites, shall be subject to a fine, the penalty of restriction of liberty or the penalty of deprivation of liberty for up to 2 years. (Polish Penal Code, 1997, Article 196)

Article 196 can be used to prosecute such crimes as the desecration of religious buildings, cemeteries, and other symbols. Article 256 applies more directly to organized movements advocating for fascist and other totalitarian ideologies that spread hatred against particular groups. Article 256 states that:

Whoever publicly promotes a fascist or other totalitarian system of state or incites hatred based on national, ethnic, racial or religious differences or for reason of lack of any religious denomination shall be subject to a fine, the penalty of restriction of liberty or the penalty of deprivation of liberty for up to 2 years. (Polish Penal Code, 1997, Article 256)

The third article relating to anti-Semitic hate crimes is Article 257. Whereas Article 256 focuses on incitement and the promotion of fascist and totalitarian ideologies, Article 257 relates more to the concept of libel against a particular group. In this way, Polish law, like German law, allows for anti-Semitic rhetoric to be prosecuted as either a form of incitement or libel. Article 257 reads: 
Whoever publicly insults a group within the population or a particular person because of his national, ethnic, racial or religious affiliation or because of his lack of any religious denomination or for these reasons breaches the personal inviolability of another individual shall be subject to the penalty of deprivation of liberty for up to 3 years. (Polish Penal Code, 1997, Article 257)

Each of these three articles in the Polish Penal Code allows the state to prosecute individuals for a number of crimes relating to anti-Semitism. Article 196 allows for the prosecution of those who desecrate religious symbols or property. Article 256 allows for the prosecution of individuals promoting fascist or totalitarian ideologies that incite hatred against specific national, ethnic, racial, or religious groups. And Article 257 allows for the prosecution against individuals who insult or libel a group based on their nationality, ethnicity, race, or religious affiliation. These provisions are common of legislation relating to hate crimes and demonstrate Poland's understanding of the state interest in such matters.

However, Poland's response to anti-Semitism is not limited to the Penal Code. The Institute of National Remembrance (IPN) was founded in 1998 by legislation passed by the Polish Parliament and began operating on July 1, 2000. The IPN's primary mission is to investigate Nazi and communist crimes committed in Poland from 1939 to 1990, but the institute has also been given prosecutorial powers to be exercised against individuals who were either responsible for committing crimes against the Polish nation or individuals who deny the facts of the crimes committed (Institute of National Remembrance, 2016a). The establishment of this particular institute and its ability to prosecute individuals on issues such as Holocaust denial is a notable element of the Polish response that is not present in the German case. In essence, the institute is a research organization with special prosecutorial powers. 
The IPN's powers are outlined in the Act of 18 December 1998 on the Institute of National Remembrance - the legislation establishing the institute. The institute's activities include the investigation and prosecution of crimes relating to both Nazism and communism. Article 1, Clause 1 of the Act states that:

Art. 1.The act regulates:

1) the recording, collecting, storing, processing, securing, making available and publishing of the documents of the state security authorities, produced and accumulated from July 22, 1944 until July 31, 1990, as well as the documents of the security authorities of the Third Reich and the Soviet Union relating to:

a)

- the Nazi crimes,

- the communist crimes, - other crimes against peace, humanity or war crimes, perpetrated on persons of Polish nationality or Polish citizens of other nationalities between September 1, 1939 until July 31, 1990 (Institute of National Remembrance, 2016b)

In short, Article 1 outlines the scope of the institute's research activities. The IPN's prosecutorial powers are stated later in Article 55, which states that "Anyone who publicly and contrary to the facts denies crimes referred to in art. 1, point 1 shall be subject to a fine or the penalty of imprisonment of up to 3 years. The sentence shall be made public" (ibid.). While Article 55 may be vague in terms of what speech can be prosecuted, certain types of anti-Semitic speech, and particularly Holocaust denial, can be viewed as denial of Nazi crimes and thus can make one the subject of prosecution.

The IPN is divided into five parts, each of which is responsible for carrying out a portion of the institute's mission. The two parts most of concern in terms of the legal measures regarding anti-Semitism and Holocaust denial are the Bureau of Provision and Archivization of Documents and the Main Commission for the Prosecution of Crimes Against the Polish Nation (Institute of National Remembrance, 2016c). The Bureau of 
Provision and Archivization of Documents is most responsible for determining the facts relating to Nazi and communist crimes against the Polish people (including Jews) and the Main Commission for the Prosecution of Crimes Against the Polish Nation is responsible for not simply prosecuting those who committed such crimes, but also those who deny the crimes. In this way, the investigation and prosecution of such offenses are centralized within a single institute and is a primary difference between how the German and Polish governments approach issues of Holocaust denial and anti-Semitic speech.

To summarize, in terms of each countries' penal code, Poland and Germany have similar laws relating to hate speech and incitement against Jews and other societal groups. Each country has laws against incitement, libel, and the promotion of fascist or totalitarian symbols. But the unique aspect of the Polish response is the role of the IPN. Poland delegates prosecutorial powers on matters of anti-Semitism to multiple agencies. Given its focus on historical research and documenting Nazi and communist crimes, the IPN is the agency most suited to prosecute crimes such as Holocaust denial, whereas the Polish Ministry of Justice and local prosecutors are more suited to prosecute other offenses relating to incitement, libel, and violence. So while Poland and Germany may have some notable differences in how crimes relating to anti-Semitism are investigated and prosecuted, both countries have nonetheless adopted laws against hate speech, incitement, and Holocaust denial and Poland has built an institution functioning in that regard.

\section{Polish-Jewish Immigration and Repatriation}

Similar to the German case, Poland has enacted laws allowing for the repatriation of citizens and their descendants who were displaced for reasons of deportation, exile, 
and persecution - reasons that affect a number of Jews with Polish roots. However, Poland has not taken the additional steps that Germany has with regard to treating Jews as a special category of refugees. In fact, the historical persecution of religious minorities is not specifically mentioned in Polish immigration and repatriation law as it is in the German case. Instead Poland makes "persons of Polish extraction" the sole category for repatriation with the same standards for all applicants, regardless of factors such as religious affiliation (Polish Ministry of the Interior, 2016).

The Polish Constitution states in Article 52, Clause 5 that "Anyone whose Polish origin has been confirmed in accordance with statute may settle permanently in Poland" (Polish Sejm, 2016). This statement is quite broad and does not provide a specific definition of "Polish origin." In order to clarify this provision, the Polish government passed the Repatriation Act of 9 November 2000. This Act has consequently become the primary law governing the repatriation of Polish citizens and their descendants persecuted under Nazism and communism.

The stated goal of the Act is to recognize that "the duty of the Polish State is to allow the repatriation of Poles who had remained in the East and in particular in the Asian part of the former Union of Soviet Socialist Republics and due to deportations, exile and other ethnically-motivated forms of persecution could not settle in Poland" (Polish Ministry of the Interior, 2016). The Act further goes on to describe the criteria necessary for one to be declared of "Polish extraction." Article 5 of the Act declares that to qualify for repatriation, one must have at least one parent or grandparent or two greatgrandparents of Polish nationality, as well as "demonstrate links with Polish provenance, in particular by cultivating Polish language, traditions and customs" (ibid.). While these 
laws do not refer to displaced Polish Jews in particular, they do nonetheless provide a path for Polish-Jewish Holocaust and other victims, as well as their descendants, to return to the country.

While Poland does indeed have laws allowing repatriation for those displaced due to Nazi and communist persecution, it is notable that Poland has not targeted such laws toward Jews, as Germany has, in order to rebuild domestic Jewish communities. Whereas Germany's Jewish population was estimated to have tripled from 1990 to 2000, in part due to the loosening of immigration restrictions on post-Soviet Jews, Poland did not experience similar growth. Estimates of the Jewish population in Poland since 1990 have consistently remained anywhere from 3,200 to 10,000 depending on the source (Jewish Virtual Library, 2016) (Yivo Institue for Jewish Studies, 2016). Of course, Poland did not explicitly state the revitalization of Jewish communities through immigration as a state goal, as was the case in Germany, and the laws tend to reflect this difference. This is not to say that Poland has not placed an emphasis on revitalizing domestic Jewish communities, but it is worth noting that the Polish response to anti-Semitism and efforts toward reconciliation with the Jewish community prioritizes Jewish immigration and repatriation to a lesser extent than in the German case.

\section{Legal Status of Judaism in Poland}

While modern Poland is overwhelmingly Catholic, the concept of religious freedom is emphasized in the Polish Constitution and has been throughout much of the country's history. Article 53, Clause 1 of the Constitution states, "Freedom and conscience of religion shall be ensured to everyone" (Polish Sejm, 2016). As of 2013, there were over 125 faith groups and religions registered with Poland's Ministry of 
Interior and Administration, and although registration is not necessary to practice one's religion, registration does provide these denominations with certain legal protections and benefits with regard to taxation (Central Statistical Office of Poland, 2013) (U.S. Department of State, 2011). The primary Jewish organization in the country is the Union of Jewish Religious Communities in Poland, which was officially registered in 1993, and is a continuation of the earlier Religious Union of Judaism established in 1946 (Union of Religious Jewish Communities in Poland, 2016). And although Polish law does not explicitly prioritize any denomination over others, the place of Judaism in the country is an issue that tends to receive significant attention.

Although Poland does not have a similar tax program to Germany, whereby parishioners contribute directly to their denomination via taxation, the government does nonetheless provide some resources and funding to religious institutions, including Judaism. The Ministry of Culture is the primary state funding source to the Jewish community in Poland and has supported a number of projects through the Union of Religious Jewish Communities in Poland (Adam Mickiewicz Institute, 2016). Most prominent among these involvements has been state funding and other support of the Foundation for the Preservation of Jewish Heritage in Poland. The Foundation is the "only institution in Poland officially dedicated to the task of recovering, preserving, and commemorating physical sites of Jewish significance" (Foundation for the Preservation of Jewish Heritage in Poland, 2016). The organization's main task is the restoration of the physical representations of Poland's Jewish community, such as synagogues, cemeteries, and other markers. An example of state funding for these efforts occurred in 2016 when 100,000 Zloty $(\$ 25,000)$ was earmarked in the Ministry of Culture's budget to be used 
toward renovations of an eighteenth century synagogue in Przysucha (Jewish Heritage Europe, 2016). Although such funding has been modest and not made on a consistent basis, the Polish government has nonetheless demonstrated a state interest in preserving Jewish religious and cultural sites within the country.

The largest single investment by the Polish government to support a Jewish institution was its contribution to the Museum of the History of Polish Jews. Construction of the building began in 2009 with the Ministry of Culture and City of Warsaw contributing PLN 150 million zloty (\$38 million) of the total PLN 320 million (\$81 million) construction costs (Polish Ministry of Culture, 2009). State officials played a visible role in establishing the museum with then-President Lech Kaczynski laying the museum's cornerstone. The museum sits on a site within the former Warsaw Ghetto and includes multimedia exhibitions and numerous artifacts of cultural and historical significance to the country's Jewish community covering approximately one thousand years of history. The museum officially opened in April 2013 and is expected to draw 450,000 visitors annually (Museum of the History of Polish Jews, 2016). In 2016, the museum was awarded the European Museum of the Year Award from the European Museum Forum (Jewish Telegraphic Agency, 2016). Although the museum serves as an institution of Jewish culture and history, and is not necessarily in and of itself a religious institution, the state funding for the project demonstrates a level of state commitment in supporting the preservation of Jewish history and culture domestically.

One particularly controversial public policy issue with regard to anti-Semitism in Poland has been that of restitution for past persecution. Many countries in Europe have taken to addressing the issue of restitution, but given that Poland until World War II had 
the world's largest Jewish community, the issue is amplified in this case. Restitution can be made for different reasons, including losses of personal property, communal property, and also personal harm. Poland has laws regarding restitution on some issues, but lacks such laws on others.

Poland remains the only country in the European Union with no law requiring private property confiscated by the Nazis, or later nationalized by the communists, to be returned to families or for the family to be compensated for such property. Since 2001, there have been at least six bills in the Polish Sejm proposing private property restitution, but these bills have either not passed or have been vetoed by the executive (World Jewish Restitution Organization, 2016). The failure to pass such legislation has received criticism from numerous Jewish organizations, especially the World Jewish Restitution Organization, and even Polish officials such as former President Bronislaw Komorowski, who in 2011 argued that the lack of a private property restitution law was "a disgrace for Poland" (Ain, 2015). With the lack of such legislation, the Polish government's official position is that private property claims should be dealt with through normal channels in the Polish courts - an often time-consuming, complex, and expensive process (World Jewish Restitution Organization, 2016a). Consequently, the issue of private property restitution remains a controversial public policy topic and point of tension between the Polish government and a number of Jewish organizations.

Nonetheless, while Poland does not have restitution laws regarding private property, the government has passed legislation and created agencies to deal with the restitution of communal property - such as synagogues, cemeteries, and other buildings serving religious, educational, cultural, and social purposes (ibid.). The Law on the 
Relationship Between the State and Jewish Communities was passed in 1997 and governs the restitution of Jewish communal properties within the country. As part of these efforts, the state also established the Polish Government Commission on the Restitution of Jewish Property, which has an equal number of officials from the Polish State Treasury and the Union of Jewish Communities (ibid.). The Commission is the primary body responsible for adjudicating claims of Jewish communal property in Poland. The Foundation for the Preservation of Jewish Heritage also partakes in the process by organizing and submitting claims. As of December 31,2015, there were 5,504 claims submitted by Jewish communities; however, only 2,645 of those claims received a positive decision or were settled by agreement (ibid.). Moreover, many of the claimed properties are in serious disrepair, the costs of which are by law to be covered fully by the property owner. This issue, while directly involving officials from both the state and the Union of Jewish Communities and having legislation enacted to govern the process, also remains a controversial point of tension between the state and a number of Jewish institutions.

It is also worth noting that Poland has enacted legislation to compensate victims of the Holocaust who were Polish citizens at the time. In 1991, the Polish government empowered the Office for War Veterans and Victims of Oppression to provide benefits to any Polish citizen who had been in a death, concentration, labor, or transit camp, or in hiding, or persecuted during the subsequent Soviet occupation until 1956 (World Jewish Restitution Organization, 2016b). However, the program received criticism from a number of organizations, including the World Jewish Restitution Organization, due to the fact that many victims no longer resided in Poland and thus did not have a Polish bank 
account - a requirement to legally receive the compensation (ibid.). Consequently, the law was amended in 2014 eliminating this requirement and allowing a greater number of Holocaust victims of Polish origin to claim benefits. The amendment has allowed tens of thousands of additional victims to claim benefits of PLN 400 (\$130) per month. Sebastian Rejak, Poland's Special Envoy to the Jewish Diaspora, has stated that "Ethnic criteria are irrelevant but we acted with a special sensitivity for the Jewish survivors of the Holocaust" and added "Jewish victims have to be looked at with special attention when we talk about World War II - that goes without saying. Their legal status is the same it's a question of sensitivity and reaching out" (Ahren, 2014). So while contemporary Poland has not legally treated Jews as a group distinct from other Poles, there have indeed been special measures taken with regard to the country's Jewish community of past and present.

\section{b. Poland's Public Diplomacy Response}

Poland's public diplomacy did not necessarily begin as a response to antiSemitism, but the issue of anti-Semitism has nonetheless become a central issue affecting both foreign and domestic perceptions of the country. The original impetus for launching a public diplomacy campaign was Poland's desire in the late 1990's and early 2000's to achieve EU accession. However, survey data determined that anti-Semitism and the legacy of the Holocaust were the foremost image among other Europeans about Poland (Ociepka and Ryniejska, 2005: 10). Such data helped craft a public diplomacy campaign that has over time made Polish-Jewish relations a central point. Consequently, Poland, and especially the governmental ministries leading the campaign, has over time fostered 
relationships with Jewish organizations foreign and domestic to demonstrate progress on the issue.

One must note that contemporary Poland does not have the level of civil society development that is observed in the German case. Therefore, Poland often has to forge partnerships with organizations based outside the country. Given Poland's comparatively large diaspora population, this has in many ways been a convenient and cost-effective approach. But beyond this, Poland has also emphasized outreach to Jewish communities and organizations, largely because there are few more credible messengers to represent Poland's progress than Jews themselves. By fostering such relationships, one could say that Judaism has increasingly been reincorporated as part of contemporary Poland's national brand. So while the German case highlighted a number of non-governmental organizations that work to counter anti-Semitism directly, the Polish case tends to be defined by the government's efforts to incorporate Judaism into Poland's national brand a message targeted not only to foreign audiences but domestic as well. Poland's means of addressing anti-Semitism through public diplomacy have tended to emphasize not simply targeting far right and other anti-Semitic groups, but rather focusing on promoting positive connections between Poles and Jews and the contributions that Jews have made to Poland - both historically and in the present.

\section{The Early Focus - Correcting Mischaracterizations}

Similar to Germany, Poland also emerged from the Cold War era seeking to improve its global standing. As has been mentioned, Poland had a number of economic, political, and social challenges in its post-communist transition that were different from the German case, and this dynamic is likely a key reason why Poland's responses to anti- 
Semitism generally developed comparatively later. Nonetheless, Poland was conscious of outside perceptions and the impacts of anti-Semitism and the Holocaust on the country's reputation. This became especially apparent as the country's efforts to achieve EU accession increased.

In a 2000 public opinion survey of Western European countries, only $44 \%$ of respondents supported the idea of Poland's accession to the European Union. While this percentage was higher than for some other post-communist countries, such as Romania (34\%) and Bulgaria (36\%), it was nonetheless shy of a majority (Eurobarometer, 2000). There were naturally a variety of reasons why some may have disapproved of this prospect; however, what Polish officials found most concerning were attitudes and misperceptions regarding Poland's role in World War II and accusations of anti-Semitism (Ociepka and Ryniejska, 2005: 6).

Extensive content analysis also revealed one of the likely factors contributing to such attitudes and accusations was the language used by media sources in Western Europe, such as "Polish concentration camps," "Polish death camps," or "Polish gas chambers." Such statements were found not only in popular media, but also in academic textbooks. A study of Western European textbooks found that phrases such as "Polish anti-Semitism" and "Polish discrimination against Jews" were commonly used without adequate mentions of Nazi occupation or figures representing the number of Polish casualties in concentration camps and uprisings (Kulczycki, 2005). Many sources also commonly failed to distinguish between the 1943 Warsaw Ghetto Uprising and the 1944 Warsaw Uprising or make adequate mention of the coordination between Jewish and Polish resistance forces in either instance (ibid.). Responding to these perceptions, and 
what many would consider mischaracterizations, became an important task for Polish authorities considering the majority of Western Europeans had never been to Poland and their perceptions and attitudes were largely shaped by second hand experiences, media coverage, and information from schools or informal groups (Ociepka and Ryniejska, 2005: 8). Indeed one of the primary purposes of public diplomacy is to respond to controversial accusations and attitudes toward a particular country, and those pertaining to Polish-Jewish relations are a prime example of the sort of questions and misperceptions that require a response.

Initially, Poland's public diplomacy efforts lacked coordination between governmental agencies and were greatly challenged by a relatively low budget and lack of communications resources. Efforts aimed to counter negative perceptions were largely handled by the Ministry of Foreign Affairs, and to a lesser extent by the Ministry of Culture. Nonetheless, with the establishment in 2002 of the 'Program for the Promotion of Poland in the EU during Ratification of the Accession Treaty,' the Ministry of Foreign Affairs gradually became the leading agency in public diplomacy efforts with a great deal of the program de-centralized and decisions being made by the individual embassy in each particular target country (Ociepka and Ryniejska, 2005: 10). These early public diplomacy efforts became known as the 'Framework Program,' which is an apt description because it only began to lay the framework for the future, more coordinated efforts that would eventually follow.

In May 2004, once Poland had attained EU accession, the Ministry of Foreign Affairs continued the public diplomacy campaign and began adopting a more coherent message and brand for the country after consulting with brand specialist Wally Olins. 
Olins believed that Poland's brand ought to invoke the message that 'Poland is part of the West and also understands the East' (Ociepka and Ryniejska, 2005: 16). Given the historical undertones of Olins' brand message, Poland was provided an ideal opportunity to determine what constitutes modern Polish identity and how negative foreign perceptions could best be addressed.

Polish-Jewish relations remained a central concern that required a coherent response. One of the ways in which the Ministry of Foreign Affairs has provided such a response has been by addressing the perpetuation of mischaracterizing language in media including the terms "Polish death camps" and "Polish gas chambers." In 2005, Polish Foreign Minister Adam Daniel Rotfeld claimed that instances of such phrases being used has been in "bad will, saying that under the pretext that 'it's only a geographic reference,' attempts are made to distort history and conceal the truth" (Zychowicz, 2005). The Polish government also began appealing to international organizations to aid in their attempts to counter mischaracterizations of Polish history. In 2007, the Polish government filed a request with UNESCO to change the official name of "Auschwitz Concentration Camp" to "Auschwitz-Birkenau" with the subtitle of "German Nazi Concentration and Extermination Camp (1940-1945)" to put greater emphasis on the Nazi German origins of the camp. UNESCO's World Heritage Committee agreed to approve the request (UNESCO, 2007). Additionally, the Ministry of Foreign Affairs has created a webpage entitled "Against Polish Camps" that attempts to chronicle instances in which media sources use such phrases and consequently demand corrections (Polish Ministry of Foreign Affairs, 2016a). Countering media reports has indeed been an important aspect of 
promoting a renewed Polish identity abroad, but it has by no means been an effort done in isolation.

\section{Creating a National Brand}

Nation branding - the development of concise messages and images to improve a country's reputation - is an element, or one may say a new method, of conducting public diplomacy. Nation branding is closely related to commercial branding, because both aim to attract support for a particular product, which in the case of nations can be their culture, political ideals, or policies. As Peter van Ham describes, "branding has become essential to create value in the relationship between territories and individuals" (2008: 128). This relationship, however, is not merely between one territory and populations outside that territory, but also those within the territory. Peter van Ham goes on to argue that "place branding is also required to make a country's image work for its economy and its citizens" (2008: 128). Such a statement invokes the idea that place or nation branding inherently has a mechanism that is connected to not only external, but also internal, populations.

In order to develop a coherent national brand, a nation's citizens must also be actively involved in developing and promoting the brand, for if they are not, the brand will likely lack credibility. In order for public diplomacy to be effective, it must have credibility, or else risk reverting to mere propaganda. As Joseph Nye explains, "Simple propaganda often lacks credibility and thus is counterproductive as public diplomacy" (2008: 101). For this reason, Poland's Ministry of Foreign Affairs has adopted a more cooperative approach, involving not only governmental agencies, but also NGOs, religious institutions and other elements of the emerging Polish civil society. 
In some ways, Poland actually benefits from being a medium-sized country with a relatively homogenous population, in that it becomes more able to establish a national brand with expediency compared to larger, more diverse countries such as Germany. Because of its size and the particular international concerns regarding the Polish nation, Poland is more able to narrow its focus on specific issues to address and incorporate into a coherent and concise brand. Since 1989, Poland has attempted to shed perceptions of its communist social identity previously imposed by the Soviet Union. Carrying on since the end of the Cold War, and emerging in 1978 with the election of Pope John Paul II, Poland has largely been defined by a Catholic identity that along with elements of the Solidarity movement has continued to the present day. Until the beginning of its public diplomacy in 2000 , however, the Polish government had not coherently projected such a national identity abroad, but since it has done so this identity has evolved and come to include additional elements, which previously remained questioned by outsiders. In order to incorporate these elements, there needed to be certain domestic developments for the promoted image or brand to remain credible. For this reason, there have indeed been linkages between Poland's public diplomacy and Polish domestic society.

\section{Current Public Diplomacy Strategies}

In the early stages of its public diplomacy campaign, particularly within the 'Framework Program,' Poland's target audiences were primarily opinion leaders and others with foreign policy influence. However, as the campaign has developed, it has increasingly reached out to the mass public as well. As was mentioned, there was little coordination between governmental agencies, much less non-governmental organizations, in Poland's early public diplomacy efforts. But this has not been the case 
since the Ministry of Foreign Affairs has taken a greater lead in embracing public diplomacy as an international strategy. Dialogical efforts that brought together the aims of the Ministry of Foreign Affairs and non-governmental agencies were not an initial emphasis of Poland's public diplomacy, but as the program progressed, coupled with an increased emphasis on nation branding, a more co-operative approach was adopted.

A common tactic to amplify messages abroad has been to engage diaspora groups, and perhaps groups with which a state has a connection but may have lost contact for a variety of reasons. Poland was ripe to make diaspora outreach a part of its public diplomacy strategy given its diaspora population of 15-20 million, a population nearly half of its own 38 million (Polish Ministry of Foreign Affairs, 2016b). Furthermore, given the questions surrounding Poland's history and relationship with the Jewish faith, there are few more credible and capable of representing Poland's progress and respect for the Jewish community than members of the community themselves. For this reason, outreach to Jewish organizations and communities has become an important aspect of Poland's public diplomacy and national branding that has not diminished, but rather built upon its post-communist Catholic and Solidarity infused national identity.

Outreach efforts that the Ministry of Foreign Affairs have undertaken to embrace Jewish groups include cultural and academic exchanges, holding conferences to promote dialogue, participation in Jewish cultural events, as well as a conscious campaign to counter the attitudes of those who may hold anti-Semitic views. Remarkably, as its national brand has gradually become an important component attempting to tie different aspects of Poland's public diplomacy together, engagement in a variety of activities has been more apt to promote a coherent message, as opposed to the less cohesive public 
diplomacy previously carried out by individual embassies. Even as public diplomacy efforts tend to be led by governmental figures and agencies in many cases, nongovernmental organizations and even individuals play an important role in communicating and exercising 'soft power' both internationally as well as domestically.

Until 2008, the Polish government did not explicitly use the term 'public diplomacy' but rather referred to 'promotion.' This changed, however, when the department responsible for promotion of the country within the Ministry of Foreign Affairs was renamed the Department of Public and Cultural Diplomacy in 2008. These efforts were accelerated in 2009 when Polish law was amended to establish public diplomacy as one of the primary missions of the Ministry of Foreign Affairs (Ociepka, 2012). These developments, while important in terms of officially establishing public diplomacy as a strategy of Polish foreign policy, were in fact a culmination of efforts that more closely coordinated efforts between governmental and non-governmental organizations.

Since its public diplomacy campaign began, the Polish Foreign Ministry has regularly held forums for increased dialogue between Polish officials, Jewish leaders, and other civil society leaders both inside and outside Poland. These forums have increased in frequency as the campaign has developed, particularly since the Department of Public and Cultural Diplomacy was established, and as of 2016, the Ministry of Foreign Affairs held approximately three or four per month (Polish Ministry of Foreign Affairs, 2016c). The topics of the forums vary, but commonly reflect themes promoting particular aspects of Polish national identity. In many cases, the forums have been held in honor of individuals who represent historical connections between Poles and Jews. Some of those 
around whom forums have been organized include: Irena Sendler, Jan Karski, and Witold Pilecki - all members of the Polish resistance known for aiding Jews during the Holocaust. Events honoring these figures have become common at Polish missions abroad and have been a central theme attempting to unite Poles and Jews, as well as create international partnerships to help enhance Polish-Jewish relations worldwide.

Indeed the first section in a 2011 report by the Ministry of Foreign Affairs chronicling past public diplomacy efforts and plans for the future is entitled "PolishJewish Dialogue." The Foreign Ministry emphasizes the importance of these efforts by stating, "Symmetric dialogue in Polish-Jewish relations is an essential part of the Polish public diplomacy. This important communication tool is used not only by governments, but also in the public spheres of individual states, whose important components are Jewish NGOs and institutions, as well as opinion-making circles within the Jewish diaspora" (Polish Ministry of Foreign Affairs, 2011). Events have included Jewish film festivals and educational programs, particularly in Israel. Through these efforts, Polish officials have attempted to embrace the Jewish elements of Poland's national identity in order to obtain partnerships to help further Poland's soft power influence abroad, and as a consequence have strengthened Jewish organizations' reach inside Poland.

\section{Attempts to Revive Domestic Jewish Culture}

Dialogue between Polish officials and Jewish communities has notably increased through formal events and partnerships that have in large part grown through public diplomacy. These efforts have been focused on Jewish groups both abroad and domestically. Some international exchange agreements have existed since the mid1990's, but have substantially increased as public diplomacy has become more organized. 
Forums for discussion have been held with far greater regularity ever since Polish-Jewish relations became a core element of public diplomacy. These efforts together have indeed contributed to an increased emphasis on Jewish culture within Poland.

It is worth noting that one of the first initiatives to create an international PolishJewish partnership began even before Poland's efforts regarding EU accession, although the program's influence has increased as the Ministry of Foreign Affairs has expanded its public diplomacy campaign. The Ministry of Foreign Affairs' bilateral agreement with the American Jewish Committee began in 1996 to create partnerships between Polish and Jewish leaders and achieve mutually beneficial goals (Forum for Dialogue Among Nations, 2016). Polish officials initially viewed the program as beneficial in terms of strengthening Poland's relationship with the United States in its efforts to attain NATO membership, and Jewish leaders became able to renew relationships with government officials and Jewish leaders in the nation that once had the world's largest Jewish population.

While not originally part of a larger, cohesive public diplomacy campaign, the Polish-Jewish Exchange Program has evolved into an important part of Poland's recent public diplomacy campaign by reaching out to important audiences with which Poland had lost much contact during the Cold War period - Jewish communities (both domestically and internationally) and Polish diaspora in the United States. In recent years, the program has put a spotlight on Poland's relationship with the Jewish community and recruited more high profile participants. Since 2000 , the program has included ministers, ambassadors, Jewish intellectuals, and journalists. One of the most notable participants was Wladyslaw Bartoszewski, Poland's former Secretary of State, 
Foreign Minister, and an Auschwitz survivor. The exchange as a whole has encouraged greater cooperation between Poles and Jews, but has also notably encouraged foreign opinion leaders to become involved within Poland's Jewish community and in many ways foster its revitalization.

Poland has also been expanding its network of Polish-Jewish exchanges with Israel, which has led to such events as the Polish Year in Israel 2008-2009. This particular event included involvement from Poland's Ministry of Culture, the Polish Institute in Tel Aviv, the Israel Philharmonic Orchestra, and other cultural institutions. From March 2008 to June 2009 over 260,000 spectators attended 140 events in 20 locations. The Polish Ministry of Culture deemed the Polish Year in Israel a success as it claimed that one in twenty Israeli adults had encountered Polish culture during the project and more than 1,500 media stories covered the events (Polish Ministry of Culture, 2015)

There is evidence that this sort of increased Polish-Jewish dialogue internationally has led to greater international funding and attention directed toward Poland's domestic Jewish community. Perhaps one of the largest and most influential Jewish organizations in Poland as of 2016 is Krakow's Jewish Community Center, which was created directly through connections and funding acquired through public diplomacy. During a 2002 visit to Krakow, Prince Charles of the United Kingdom met with Jewish leaders in the Kazimierz District and learned that Krakow's Jewish community did not have a meeting place outside of their individual synagogues. After the meeting, Prince Charles personally vowed to help secure funding for a Jewish center in the city in order to help bring Krakow's Jewish community together (Jewish Community Center of Krakow, 2013). Prince Charles's involvement helped draw attention to the cause and compel World 
Jewish Relief and the American Jewish Joint Distribution Committee to also help raise funds and contribute resources. In November 2006, ground was broken on which the 10 million zloty (\$3.5 million) center was to be built. The center was completed in April 2008 with Prince Charles and the Duchess of Cornwall formally opening the center (ibid.).

Since Krakow's Jewish Community Center has opened, it has become an attraction for Jews, non-Jews, and tourists to come together and learn about Jewish culture and participate in Jewish cultural events, holidays, and other traditions. There are currently 400 active members of the center, which considering the estimated Jewish population in Poland of only 3,200 to 10,000 is substantial (Jewish Community Center, 2012). Membership is, however, not a condition for participation in activities run by the center, in fact, it has been routine for the center to leave its doors open to any who desire to enter without any security guards (ibid.). Krakow's Jewish Community Center is an important cultural institution that has been influential in the revival of Jewish life in the country, but it has also been complemented by other instances of public diplomacy having an effect on Poland's Jewish communities.

One of the most visible examples of the Jewish revival has been in Krakow with noticeable increases in attendance and funding for the annual Krakow Jewish Cultural Festival. The festival actually began in 1988 when twenty-eight year old Janusz Makuch, a collector of films about Israel and traditional Jewish music, decided to gather with friends from the local Jewish community at Krakow's Mikro movie theater for a film screening and series of lectures. In its early years, the event lacked funding and could only be held every other year. However, Poland's Ministry of Culture eventually 
discovered the public diplomacy potential of the event and began offering funding to make the event an annual affair (Tzur, 2013). Since then, the festival has gradually added donors and partner organizations, and in 2009 began organizing year-round workshops, presentations, and concerts (Inside-Poland, 2013). The festival itself is held annually in June with approximately 30,000 people attending, a remarkable number given the fact that Poland's entire Jewish community is only estimated to be between $3,200-10,000$. The 2013 budget for the festival reached $\$ 1$ million with most contributions coming from the Polish government and international Jewish organizations (Tzur, 2013) - a partnership strengthened through public diplomacy initiatives. These efforts have been amplified through media coverage as the final open-air concert of the festival known as "Szalom on Szeroka Street" is televised live on national television and the event is now customarily held under the patronage of the President of the Republic of Poland. It is also worth noting that the aforementioned Jewish Community Center of Krakow has become one of the chief partner organizations for the festival (Zubryzycki, 2012: 447). For these reasons, the festival has received international attention and recently began accepting donations from the Swiss government, Goldman Sachs, and other international entities (Jewish Community Center of Krakow, 2013), consequently drawing international attention to progress in Polish-Jewish relations and helping move beyond the negative perception of Poland representing a Jewish graveyard.

Jewish cultural festivals have, however, not been limited to Krakow. There are now some 16 Jewish cultural festivals in 13 cities throughout Poland (Zubryzycki, 2012: 447). Krakow has nonetheless become the center of the recent Jewish revival with other organizations being created and building off the success of the cultural festival. Beit 
Krakow, a progressive Jewish group, led by Poland's first female rabbi who came to the country via Israel in 2007 with the intent of helping revive the Jewish community has held over five hundred of its own cultural and religious events celebrating contemporary Jewish life in Poland since 2009. Beit Krakow has reached out to international performers to visit and present classic Hebrew texts to contemporary audiences through music, dance, and theatre (Jarosz, 2013). Performers have visited from countries such as Israel and Russia, and consequently these partnerships have helped to serve Poland's public diplomacy goals by projecting the image of a vibrant Jewish community internationally with credibility behind the claim.

Interestingly, these events have not been targeted exclusively toward Polish Jews, but more generally toward anyone with an interest in Jewish culture. In fact, an estimated $85 \%$ of attendees at the Krakow cultural festival are non-Jews (Schaechter, 2007). This recent popularity of Jewish culture has also led to increases in Jewish businesses as Poland has become increasingly commercialized. Before World War II, Jewish cafes and markets were a common sight throughout Poland, but after decades of Nazi and communist rule, this was no longer the case. In the early 1990's, Krakow's historically Jewish Kazimierz District had no businesses with roots in Jewish culture or tradition. The first Jewish café opened in 1992, but had little indication of any other Jewish themed establishments in the surrounding area in the years following. This changed, however, as the Jewish Cultural Festival has gained in popularity. As of 2012, there were over a dozen Jewish establishments in the Kazimierz District alone (Grollmus, 2012). Some have questioned the authenticity of such establishments, since many owners are in fact non-Jews and many Jewish cafes are non-kosher. Although this may be the case, the fact 
that embracing Jewish culture is not only an initiative undertaken by a few elites, but rather is also a popular and commercial success is one indication of improvement between Poles, Jews, and outside perceptions of the Polish-Jewish relationship.

Some have argued that the increased emphasis on common Polish-Jewish history and the conscious efforts to establish Judaism as an element of Polish national identity has been merely an attempt by progressives to introduce pluralism into a country that is 96\% ethnically Polish and 95\% Catholic (Zubryzycki, 2012: 444). Indeed there has been some backlash from conservative nationalists who point to Poland's homogeneity as a reason to implement conservative social policies. However, this has not universally been the case. In fact, one of the most elaborate projects undertaken to emphasize PolishJewish commonalities began under the leadership of the conservative Law and Justice Party. The decision to create Warsaw's Museum of the History of Polish Jews was made in 2005 with the cornerstone for the building being laid in June 2007 by President Lech Kaczynski of the Law and Justice Party.

The Ministry of Culture and City of Warsaw, at the time also led by a Law and Justice government, each contributed toward the 43,000 square foot building's construction on the edge of Warsaw's former Jewish Ghetto with an additional $\$ 40$ million being raised by international NGOs to finance the museum's exhibitions (Museum of the History of Polish Jews, 2016). Exhibitions feature multimedia content about the historical vibrancy of Poland's Jewish community, covering over one thousand years of Jewish contributions to Polish society. Additionally, the museum is being complemented by an online project called the "Virtual Shtetl," which launched in 2009 and offers Polish-English websites that list maps of 1,240 Polish towns with statistics and 
picture galleries providing information on Jewish life in Poland prior to World War II and the Holocaust (ibid.). Such initiatives are consistent with the common theme throughout Polish public diplomacy of emphasizing positive contributions that Jews have historically made to Polish society and the role they have played in shaping the country's identity.

\section{Conclusion}

Poland's response to anti-Semitism shares some similarities with the German approach with a few notable differences. Both countries indeed have laws prohibiting Holocaust denial and certain anti-Semitic speech, but Poland's establishment of the Institute of National Remembrance and its prosecutorial powers provides an additional means of countering anti-Semitic speech. The Polish government has also publicly and financially supported a number of Jewish cultural, social, and even religious institutions albeit via direct funding as opposed to the German approach of levying taxes on parishioners. Nonetheless, controversy remains about inconsistent and complex policies regarding restitution for Polish-Jews who suffered historical persecution.

Poland's public diplomacy campaign has had less of a focus on addressing and confronting anti-Semitic groups directly, but rather has focused on fostering positive relationships with Jewish organizations and emphasizing to the wider public the positive contributions the Jewish community has made to Poland. The initiatives for spreading such messaging have involved bilateral exchange agreements, supporting Jewish institutions and events, and supporting educational initiatives through centers such as the recently opened Museum of the History of Polish Jews. Poland does not have a similar level of NGOs and other initiatives to directly confront anti-Semitic groups and parties as is observed in the German case - instead Poland has placed greater emphasis in its 
messaging on incorporating Jewish life into Poland's modern identity in a manner that appeals to Polish Jews and non-Jews alike. These efforts have been aimed at emphasizing cooperation between these groups for the purposes of both countering domestic antiSemitism and projecting a tolerant image and brand of the country abroad. These initiatives and themes have been the defining characteristics of Poland's response to antiSemitism. So while Germany and Poland have similar goals in mind with regard to addressing the problem of anti-Semitism, there are indeed some notable differences in terms of the measures taken and development of the response.

\section{References}

Adam Mickiewicz Institute (2016). Union of Religious Jewish Communities in Poland, http://www.diapozytyw.pl/en/site/organizacje/zwiazek, accessed on 18 May 2016.

Ahren, Raphael (2014). In First, Poland to Pay Reparations to Holocaust Survivors Abroad, Times of Israel, online publication 28 May: http://www.timesofisrael.com/for-first-time-poland-to-pay-pensions-to-survivors/, accessed on 21 May 2016.

Ain, Stewart (2015). New Pressure on Poland for Property Restitution, http://www.thejewishweek.com/news/international/new-pressure-polandproperty-restitution, accessed on 20 May 2016.

Central Statistical Office of Poland (2013). Report on Religious Associations and EthnicNationality in Poland 2009-2011, http://stat.gov.pl/cps/rde/xbcr/gus/oz_wyznania_religijne_stow_nar_i_etn_w_pol_ 2009-2011.pdf, accessed on 17 May 2016.

Coordination Forum for Countering Anti-Semitism (2011). Public Opinion Poll: Jew, I Am Not Fearful of You, online publication September 2:

http://antisemitism.org.il/article/63205/public-opinion-poll-jew-i-am-not-fearfulyou.

Eurobarometer (2000). Percentage in Favor of Potential Candidate Countries, http://ec.europa.eu/public_opinion/index_en.htm, accessed 16 May 2016. 
Forum for Dialogue Among Nations (2016). Polish-Jewish Exchange Program, http://www.dialog.org.pl/en/polish-jewish_exchange_program.html, accessed 16 May 2016.

Foundation for the Preservation of Jewish Heritage in Poland (2016). About Us, http://fodz.pl/?d=3\&l=en, accessed on 18 May 2016.

Grollmus, Denise (2012). Poland's Real Jewish Revival, Tablet, online publication November 26: http://www.tabletmag.com/jewish-life-andreligion/116890/polands-real-jewish-revival.

Inside-Poland (2013). Krakow's Festival of Jewish Culture - 25 Years on, online publication 25 June, http://inside-poland.com/t/krakows-festival-of-jewishculture-25-years-on/, accessed 18 May 2016.

Institute of National Remembrance (2016a). About the Institute of National Remembrance, http://ipn.gov.pl/en/about-the-institute/institute-of-nationalremembrance-commission-for-the-prose, accessed on 10 May 2016.

Institute of National Remembrance (2016b). Act on the Institute of National Remembrance, http://ipn.gov.pl/en/about-the-institute/documents/institutedocuments/the-act-on-the-institute-of-national-remembrance, accessed on 10 May 2016.

Institute of National Remembrance (2016c). Amendments to the Act on the Institute of National Remembrance, http://ipn.gov.pl/najwazniejsze-wiadomosci/zmiany-wustawie-o-instytucie-pamieci-narodowej-oraz-w-ustawie-o-ujawnianiu-info, accessed on 10 May 2016.

Jarosz, Andy (2013). New Life in Krakow's Jewish Quarter, BBC, online publication February 17: http://www.bbc.com/travel/feature/20130126-new-life-in-krakowsjewish-quarter.

Jewish Community Center (2012). Building a Jewish Future in Krakow, https://jewsofkrakow.wordpress.com/tag/jews-in-poland/, accessed 18 July 2013.

Jewish Community Center of Krakow (2013). Our Story, http://www.jcckrakow.org/subpages/1, accessed 16 July 2013.

Jewish Heritage Europe (2016). Poland: More Funding for Przysucha Synagogue Restoration, http://www.jewish-heritage-europe.eu/2016/03/23/poland-morefunding-for-przysucha-synagogue-restoration/ $\% \mathrm{E} 2 \% 80 \% 9 \mathrm{D}$, accessed on 18 May 2016. 
Jewish Telegraphic Agency (2016). Polish Jewry Museum Wins European Museum of the Year Award, http://www.jta.org/2016/04/10/news-opinion/world/polishjewry-museum-wins-european-museum-of-the-year-award, accessed on 19 May 2016.

Jewish Virtual Library (2016). Virtual Jewish History Tour: Poland, http://www.jewishvirtuallibrary.org/jsource/vjw/Poland.html, accessed 13 May 2016.

Kulczycki, John (2005). Eastern Europe in Western Civilization Textbooks: The Example of Poland, The History Teacher 38 (2): 163-167.

Museum of the History of Polish Jews (2016). About the Museum, http://www.jewishmuseum.org.pl/en/about-museum, accessed 15 May 2016.

Nye, Joseph (2008). Public Diplomacy and Soft Power, Annals of the American Academy of Political and Social Science 616: 94-109.

Ociepka, Beata and Marta Ryniejska (2005). Public Diplomacy and EU Enlargement: The Case of Poland, Netherlands Institute of International Relations, http://www.clingendael.nl/sites/default/files/20050800_cli_paper_dip_issue99.pdf

Olins, Wally (2000). Trading Identities: Why Countries and Companies Are Taking on Each Others' Roles, London: Foreign Policy Centre.

Polish Ministry of Culture (2009). Construction Begins on the Museum of the History of Polish Jews, http://mkidn.gov.pl/pages/posts/rozpoczeto_budowe_muzeum_historii_zydow_po lskich-196.php, accessed on 19 May 2016.

Polish Ministry of Culture (2015). Cultural Seasons and Major Events, http://www.mkidn.gov.pl/pages/the-ministry-of-culture-and-nationalheritage/cultural-seasons-and-major-events.php, accessed 20 May 2015.

Polish Ministry of Foreign Affairs (2011). Public Diplomacy 2011, http://broszury.msz.gov.pl/dp_en/, accessed 17 May 2016.

Polish Ministry of Foreign Affairs (2016a). Against Polish Camps, http://www.msz.gov.pl/en/foreign_policy/against_polish_camps/, accessed 17 May 2016.

Polish Ministry of Foreign Affairs (2016b). Polish Diaspora, http://www.msz.gov.pl/en/foreign_policy/polish_diaspora/, accessed 17 May 2016. 
Polish Ministry of Foreign Affairs (2016c). Public Diplomacy, http://www.msz.gov.pl/en/foreign_policy/public_diplomacy/, accessed 18 May 2016.

Polish Ministry of the Interior (2016). The Repatriation of 9 November 2000, https://mswia.gov.pl/en/document/the-repatriation-act-o/28,The-Repatriation-Actof-9-November-2000.html, accessed 13 May 2016.

Polish Penal Code (1997). The Penal Code, https://www.imolin.org/doc/amlid/Poland_Penal_Code1.pdf, accessed on 11 May 2016

Polish Sejm (2016). The Constitution of the Republic of Poland of April 2, 1997, http://www.sejm.gov.pl/prawo/konst/angielski/kon1.htm, accessed on May 9, 2016.

Schaechter, Rukhl (2007). Krakow Jewish Fest Features Notable Absence: Jews, The Jewish Daily, online publication July 13:

http://forward.com/articles/11142/krakow-jewish-fest-features-notable-absencejews/.

Tzur, Nissan (2012). Recent Converts Offer a Glimpse of Judaism's Appeal in Poland, The Times of Israel, online publication November 4: http://www.timesofisrael.com/recent-converts-offer-a-glimpse-of-judaismsappeal-in-poland/.

UNESCO (2007). World Heritage Committee Approves Auschwitz Name Change, http://whc.unesco.org/en/news/363/, accessed on 20 May 2015.

Union of Jewish Religious Communities in Poland (2016). About the Organization, http://www.izrael.badacz.org/zydzi_w_polsce/org_zwiazek.html, accessed on 17 May 2016.

U.S. Department of State (2011). International Religions Freedom Report for 2011 Poland, http://www.state.gov/documents/organization/193061.pdf, accessed on 17 May 2016.

van Ham, Peter (2008). Place Branding: The State of the Art, Annals of the American Academy of Political and Social Science 616: 126-149.

World Jewish Restitution Organization (2016a). Timeline: Private Property Restitution in Poland, http://wjro.org.il/our-work/restitution-by-country/poland/timelinepoland/, accessed on 20 May 2016. 
World Jewish Restitution Organization (2016b). Polish Benefits for Holocaust Victims of Polish Origin, http://wjro.org.il/polish-benefits/, accessed on 21 May 2016.

Yivo Institute for Jewish Studies (2016). Poland Since 1939, http://www.yivoencyclopedia.org/article.aspx/poland/poland_since_1939, accessed 13 May 2016.

Zubrzycki, Genevieve (2012). Religion, Religious Tradition, and Nationalism: Jewish Revival in Poland and 'Religious Heritage' in Quebec, Journal for the Scientific Study of Religion 51 (3): 442-455.

Zychowicz, Peter (2005). Interview with the Minister of Foreign Affairs of the Republic of Poland, Prof. Adam Daniel Rotfeld. Rzeczpospolita, online publication January 25: http://www.msz.gov.pl/gallery/serwis/rot_rzecz_1251.html. 


\section{CHAPTER VI}

\section{EVALUATING THE EFFECTIVENESS IN GERMANY}

This chapter will present data on a number of indicators of anti-Semitism and consequently evaluate the effectiveness of state policies toward anti-Semitism in Germany. The data used to evaluate the effectiveness of these policies include: membership in far right groups; election results for far right political parties; anti-Semitic attitudes, violent attacks, and crimes; and perceptions of anti-Semitism from the domestic Jewish community. Each of these indicators helps to evaluate the effectiveness of the state policies explained in previous chapters by demonstrating trends over time. In analyzing these data, one is able to develop a better understanding of the areas where these policies have been most and least effective. Particularly important to note are changes in the data following policy implementation. As explained in previous chapters, the first policies implemented were increasing Jewish immigration (1991) and a ban on Holocaust denial (1994). The public diplomacy initiatives in Germany were launched following the publication of the Konzeption 2000 by the Federal Foreign Office in 1999. Shortly thereafter, Judaism was granted full legal status and increased benefits from the German government in 2003. This timeline of policy implementation will be essential with regard to this chapter's data analysis.

\section{a. The Influence of Far Right Groups}

As was mentioned in Chapter 3, many of the German legal and public diplomacy responses to anti-Semitism focus on countering far right extremist groups. Groups classified as far right include Neo-Nazis, skinheads, and certain political parties, such as the NPD (National Democratic Party of Germany), Die Republikaner, the former DVU 
(German People's Union), and other groups with similar ideologies. As will be demonstrated later, these groups are responsible for approximately $93 \%$ of all antiSemitic crimes and $87 \%$ of violent anti-Semitic attacks. Consequently, countering these groups has been a top priority of the German response to anti-Semitism. Germany's Federal Office for Protection of the Constitution tracks membership in such groups and releases the data via annual reports on extremism. Figure 5.1 graphs some of these membership data.

\section{Figure 5.1}

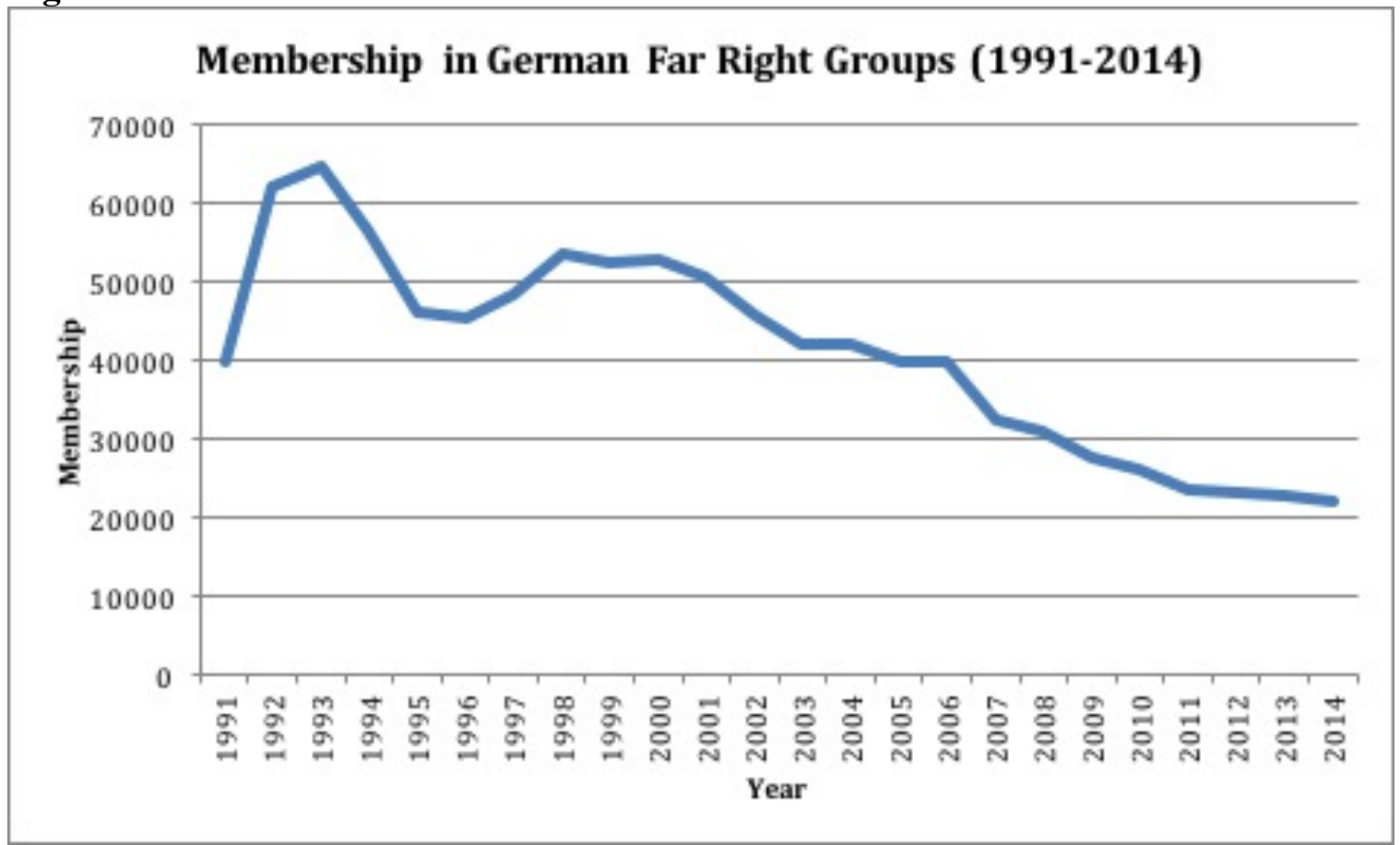

Source: Federal Office for Protection of the Constitution, available at https://www.verfassungsschutz.de/de/oeffentlichkeitsarbeit/publikationen/verfassungssch utzberichte

Figure 5.1 shows that membership in far right groups reached its peak in the early 1990's and has generally declined since that time. These data indicate that efforts to counter far right groups have been effective in terms of decreasing membership and the ability of such groups to recruit new members. This decrease is especially notable after 
2000 - the year in which Germany's public diplomacy campaign was launched. It was also around this time that civil society organizations, such as the Center for Democratic Culture (ZDK) and Amadeu Antonio Foundation (AAS), were established and began implementing strategies to counter the influence of the far right. Prior to 2000, far right group membership tended to be more volatile, but since that time the data has shown steady declines in membership. As of 2014, membership in German far right groups has decreased by approximately two-thirds from their highpoint in 1993. While it is true that membership in German political parties overall also declined over this period - with an average decline of $27 \%$ from 1993 to 2014 - far right groups have experienced a $66 \%$ decrease over the same period (Niedermayer, 2016: 2). This discrepancy indicates that there are likely additional factors influencing the sharp declines in far right group membership. Particularly since these declines were sharpest after the year 2000, it is likely that public diplomacy initiatives were a contributing factor.

However, while the data shows that membership in far right groups as a whole has declined, the success of far right parties in national and local elections has not necessarily reflected the same trend (see Figure 5.2). 
Figure 5.2

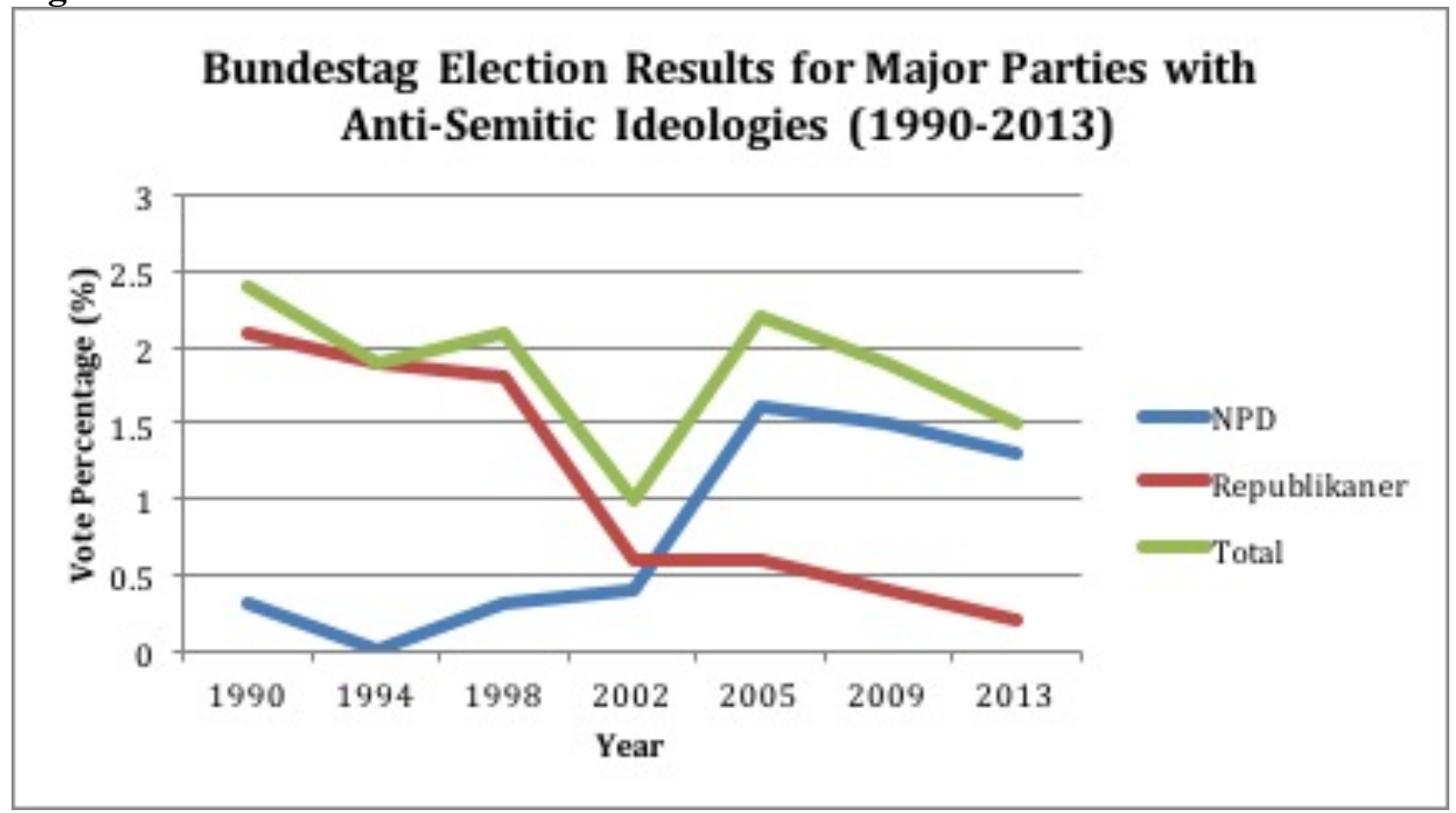

Source: Wahlrecht.de (2016). Election Results, available at http://www.wahlrecht.de/ergebnisse/index.htm

With the exception of 2002, aggregate electoral support for the two major far right parties, the NPD and die Republikaner, in national Bundestag elections has remained between $1.5 \%$ and $2.5 \%$. These results show that while die Republikaner have declined in national electoral support since 1990, the NPD has gained over the same period. 2002 was a rare year in which both parties' vote percentage remained under $1 \%$. Since German reunification in 1990 , neither party has achieved the requisite $5 \%$ of the vote necessary to have seats in the Bundestag, but the fact that electoral support for these parties has generally remained within the same $1.5 \%$ to $2.5 \%$ range is notable. This trend differs from the data in Figure 5.1 showing far right group membership as a whole declining over time. So while efforts to counter the influence of far right groups in the country appear to have been relatively successful with regard to reducing membership, these 
efforts do not appear to have had similar effects on total electoral support for the two major far right political parties.

Although neither of the major far right parties has achieved national representation in the Bundestag, there have been two state legislatures where the NPD has been successful in winning seats. The NPD was able to break the $5 \%$ threshold necessary for representation in the Saxon Landestag in 2004 and the MecklenburgVorpommern Landestag in 2006, as shown in Table 5.1.

\section{Table 5.1}

\begin{tabular}{|c|c|c|c|c|c|}
\hline \multicolumn{7}{|c|}{ NPD Landestag Election Results } \\
\hline Year & Vote \% & Seats & Year & Vote \% & Seats \\
\hline $\mathbf{1 9 9 0}$ & 0.7 & 0 & $\mathbf{1 9 9 0}$ & 0.2 & 0 \\
\hline $\mathbf{1 9 9 4}$ & 0 & 0 & $\mathbf{1 9 9 4}$ & 0.1 & 0 \\
\hline $\mathbf{1 9 9 9}$ & 1.4 & 0 & $\mathbf{1 9 9 8}$ & 1.1 & 0 \\
\hline $\mathbf{2 0 0 4}$ & 9.2 & 12 & $\mathbf{2 0 0 2}$ & 0.8 & 0 \\
\hline $\mathbf{2 0 0 9}$ & 5.6 & 8 & $\mathbf{2 0 0 6}$ & 7.3 & 6 \\
\hline $\mathbf{2 0 1 4}$ & 4.95 & 0 & $\mathbf{2 0 1 1}$ & 6 & 5 \\
\hline
\end{tabular}

Source: Wahlrecht.de (2016). Election Results, available at http://www.wahlrecht.de/ergebnisse/index.htm

In 2004, the NPD achieved its largest electoral victory in reunified Germany winning $9.2 \%$ of the vote and gaining twelve seats in the Saxon Landestag election. The party has lost support in subsequent elections, losing four seats and only earning $5.6 \%$ of the vote in 2009 , and then in 2014 the party was unable to reach the 5\% threshold and consequently lost its representation in the Landestag. In Mecklenburg-Vorpommern, the NPD experienced a sharp rise in support to $7.3 \%$ of the vote in 2006 from $0.8 \%$ in the previous election in 2002 . The party consequently won six seats in the Landestag. 
Although losing one seat in 2011 , the party did indeed meet the requisite threshold to keep representation and earned $6 \%$ allowing it to hold five of its previous six seats.

These results are notable, because they demonstrate that while membership in far right groups as whole has decreased and total electoral support of the NPD has remained below $1.5 \%$ in national elections since 1990 , the NPD has had greater success in some state elections in the former East Germany. It is also notable that the party was unable to achieve such success until 2004. These factors indicate mixed results in regard to the success of German policy and public diplomacy responses to counter far right groups and political parties. While overall membership in such groups has indeed declined, national electoral results have remained relatively consistent, and in some state elections these parties have in fact achieved even greater success than they had in the 1990's. Therefore, the data suggest that efforts to counter the influence of far right groups have been more successful in terms of reducing overall membership, but less successful in reducing the support of far right parties in elections.

\section{b. Anti-Semitic Attitudes}

While many of the German efforts to counter anti-Semitism are focused on far right groups, it is also important to evaluate these policies' effectiveness on the general German population. As noted in Chapter 3, Germany has attempted to demonstrate progress on the issue of anti-Semitism through its public diplomacy messaging. In order to do so, these efforts have required a substantial amount of domestic engagement, both with NGOs and governmental agencies. A number of programs and legal measures have been adopted to facilitate such engagement and reduce the influence and prevalence of anti-Semitic ideologies and attitudes. Although there has not been a reliable and 
consistent survey tracking data on anti-Semitic attitudes in Germany since 1990, the University of Leipzig in conjunction with the Friedrich Ebert Stiftung has been collecting such data since 2002. The survey data from these organizations does not provide a complete picture of anti-Semitism since reunification, but nonetheless does provide insight with regard to recent trends. Figure 5.3 displays these survey results since $2002-$ tracking not only attitudes of the general German population, but also the differences in attitudes between the states of the former East Germany and West Germany.

\section{Figure 5.3}

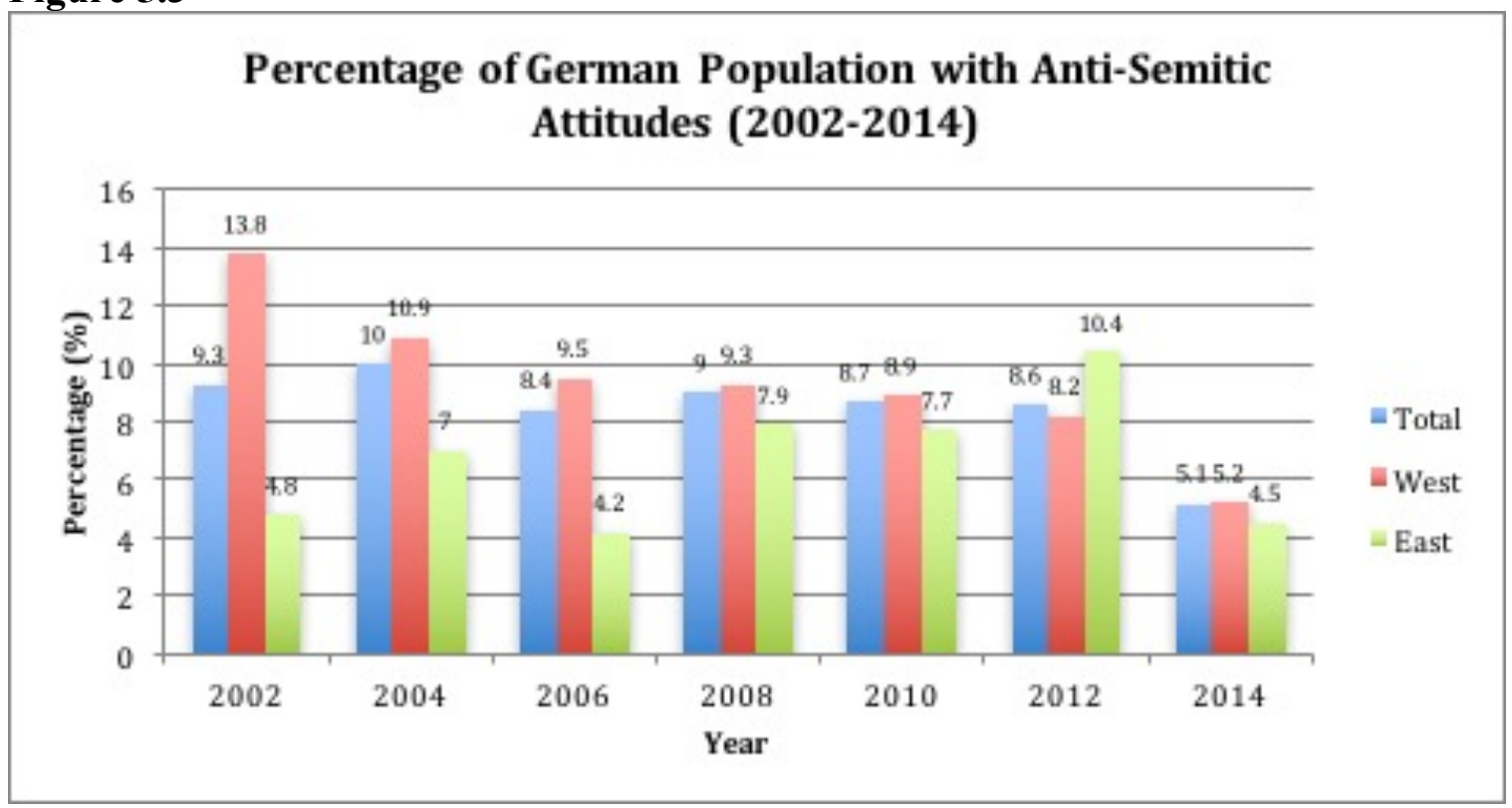

Source: Decker, 2014

The data show that total anti-Semitic attitudes in Germany have decreased in each biannual survey since 2002 , falling from $13.8 \%$ in 2002 to $5.2 \%$ in 2014 . These trends tend to mirror the data in Figure 5.1 that showed membership in far right groups decreasing over the same period. Such results indicate that German policy responses to anti-Semitism have been effective in reducing anti-Semitic attitudes among the general German population. 
Also notable from Figure 5.3 is that, with the exception of 2012, anti-Semitic attitudes in the states of the former East Germany (although more volatile) have been lower than in the states of the former West Germany. These data would seem counterintuitive considering the electoral successes and relative strength of the NPD and other far right parties and groups in the states of the former GDR. However, one likely explanation for this seeming discrepancy is that anti-Semitism may not be the primary motivating factor for individuals to join far right groups or vote for far right parties. The data in Figure 5.4 may help to provide some additional insight.

\section{Figure 5.4}

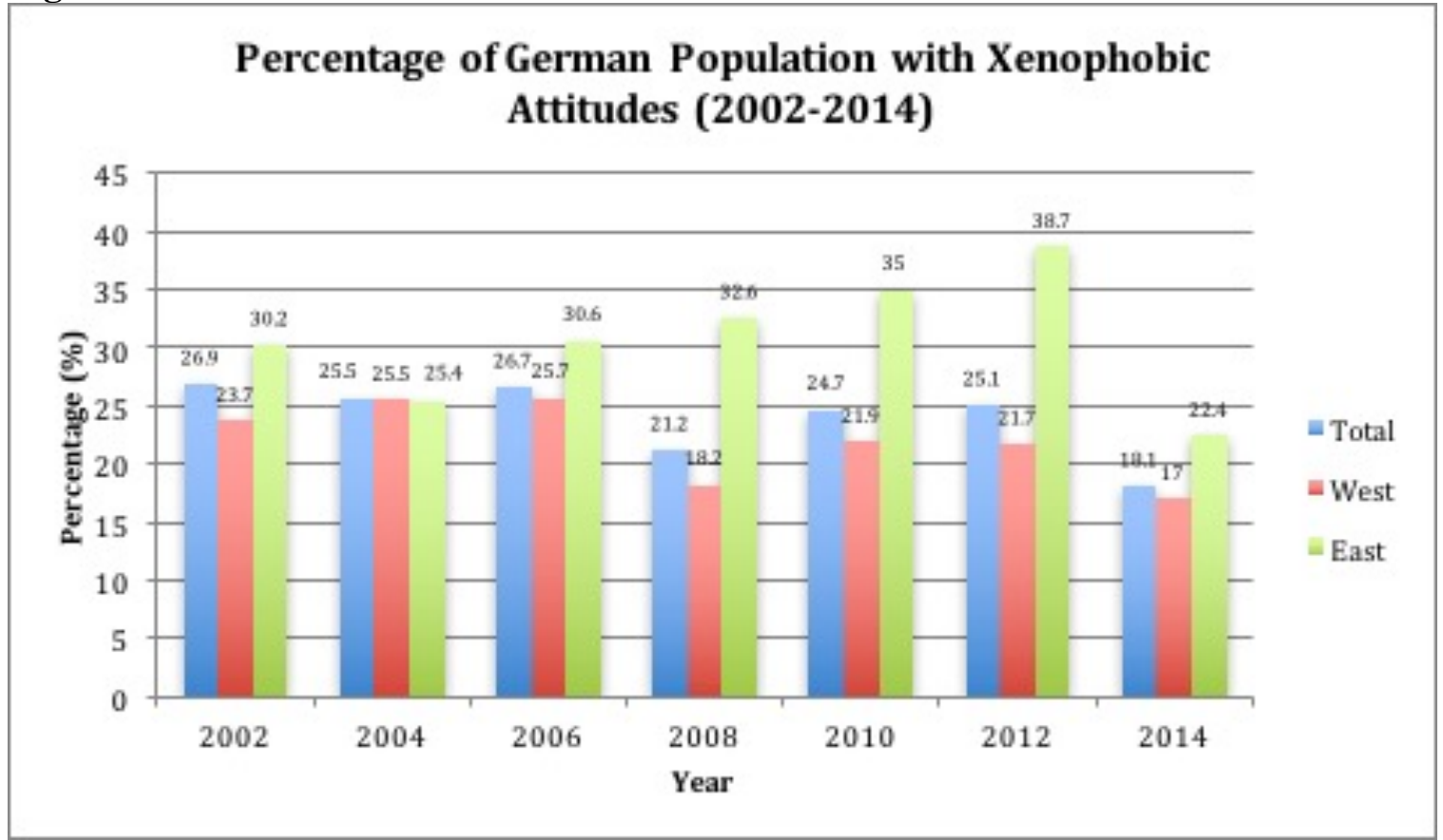

Source: Decker, 2014

Figure 5.4 shows that although the states of the former East Germany may tend to have lower levels of anti-Semitism, these states tend to have higher levels of xenophobic attitudes than Western Germany and the general German population. This dynamic may help to explain the relative successes of far right parties in this region of the country. 
While anti-Semitism is certainly a common element in the platforms of many far right parties and groups, it may not be as prevalent of a motivation as xenophobia for those who decide to join or vote for such parties and groups. Levels of xenophobic attitudes have shown to be generally two to three times more prevalent in each category than antiSemitic attitudes over the period measured. However, given that approximately $90 \%$ of German Jews are also immigrants, there may indeed be an area of overlap between antiSemitic and xenophobic attitudes (Ben-Rafael, 2015: 57). In other words, hatred directed toward members of Germany's Jewish community may not be entirely anti-Semitic, as the prevalence of xenophobic attitudes may also lead to hatred and discrimination toward members of the community.

Although data on the subject has not been collected consistently, survey research has shown that anti-Semitic attitudes have tended to be higher among Germany's Muslim population than the general or Christian populations. A 2006 survey conducted by Pew Research showed that $44 \%$ of German Muslims viewed Jews either very unfavorably (31\%) or somewhat unfavorably (13\%). These levels were higher than for the general German population, in which $22 \%$ viewed Jews either very unfavorably $(5 \%)$ or somewhat unfavorably (17\%) (Pew Research Center, 2006). Another survey in 2013 showed similar results in which $28 \%$ of German Muslims stated they could not trust a Jewish person compared to $10.5 \%$ for German Christians (Jikeli, 2015). It is not possible to demonstrate a trend with these data, given that the questions asked differ, but the results do indeed demonstrate a difference with regard to religious anti-Semitism in Germany. The data suggest that the German responses to anti-Semitism tend to have less salience in terms of reaching and influencing the country's Muslim population. 
Another important indicator of anti-Semitism is the prevalence of attacks and crimes committed with an anti-Semitic motive. As described in earlier chapters, Germany has adopted certain hate crimes legislation regarding anti-Semitism (first adopted in 1960 and expanded in 1994) and the Ministry of the Interior in fact maintains data on the number of anti-Semitic violent attacks and overall anti-Semitic crimes committed. Behavior intended to physically harm another person or persons are considered to be violent attacks, whereas the data representing total anti-Semitic crimes includes violent attacks, hate speech, and intentional damage to property. Figure 5.5 represents violent anti-Semitic attacks in Germany from 1991 to 2015 and Figure 5.6 represents the total number of anti-Semitic crimes from 1991 to 2014. 


\section{Figure 5.5}

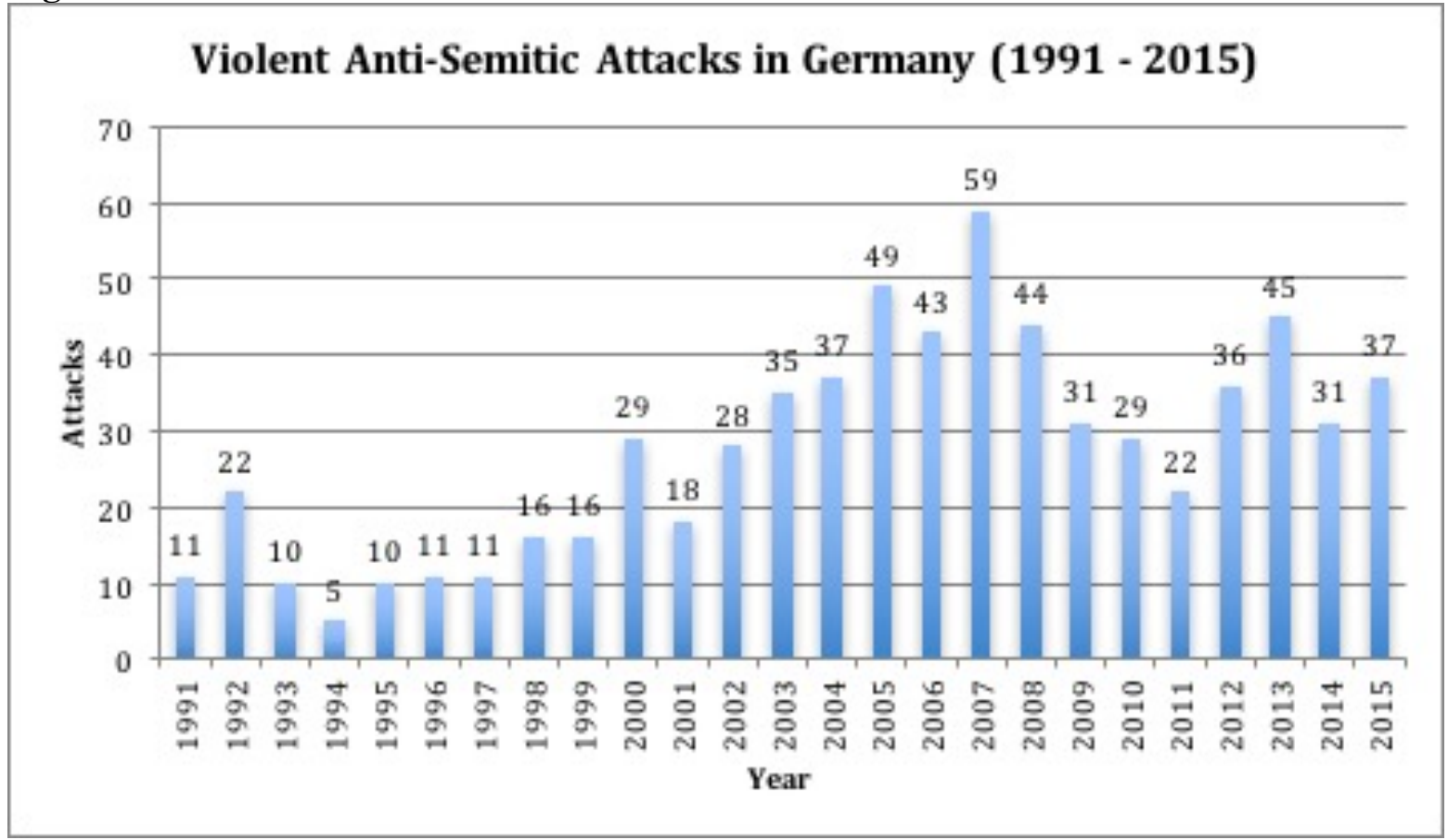

Source: Federal Office for Protection of the Constitution, available at https://www.verfassungsschutz.de/de/oeffentlichkeitsarbeit/publikationen/verfassungssch utzberichte

As Figure 5.5 shows, the number of violent anti-Semitic attacks in Germany has not followed a linear trend. The number of attacks recorded tended to be lower in the 1990's, increasing to a highpoint in 2007, and has generally, but not consistently, declined since that time. There are a number of possible explanations for these numbers. One potential explanation for the relatively low number of violent anti-Semitic attacks during the 1990's is that the Jewish population in Germany was much smaller than in the years since 2000. According to the Central Council of Jews in Germany, the country's Jewish population tripled from 28,000 in 1990 to 88,000 in 2000 (Klusmeyer and Papademetriou, 2013: 190). Consequently, since 2000 there have simply been more German Jews who could be potential victims of attacks. A second possible explanation is that external events may lead to increased attacks in particular years. Controversy over 
foreign policies, particularly with regard to Israel, as well as other economic, political, social, religious and other developments all have the potential to stoke the primary manifestations of anti-Semitism that have long played a role in Germany's history and affairs. A third possible explanation is that the state responses to anti-Semitism have not been consistently successful in preventing violent attacks. Figures 5.1 and 5.3 showed that membership in far right groups and anti-Semitic attitudes have tended to consistently decline since at least 2002. This has not been the case with violent attacks. After that, the frequency of occurrence of such violence has been up and down, following no particular trend. Thus, these data do not offer clear and sufficient evidence for a reduction in the number of violent anti-Semitic attacks in Germany.

In order to paint a more complete picture of levels of anti-Semitism, it is also important to examine the overall number of anti-Semitic crimes over time. The numbers in Figure 5.6 include violent anti-Semitic attacks, but also those crimes involving hate speech and damage to property. The numbers show that only about $2.1 \%$ of all antiSemitic crimes since 1991 are violent attacks against others; the vast majority of antiSemitic crime is categorized into the latter categories of hate speech and damage to property. 
Figure 5.6

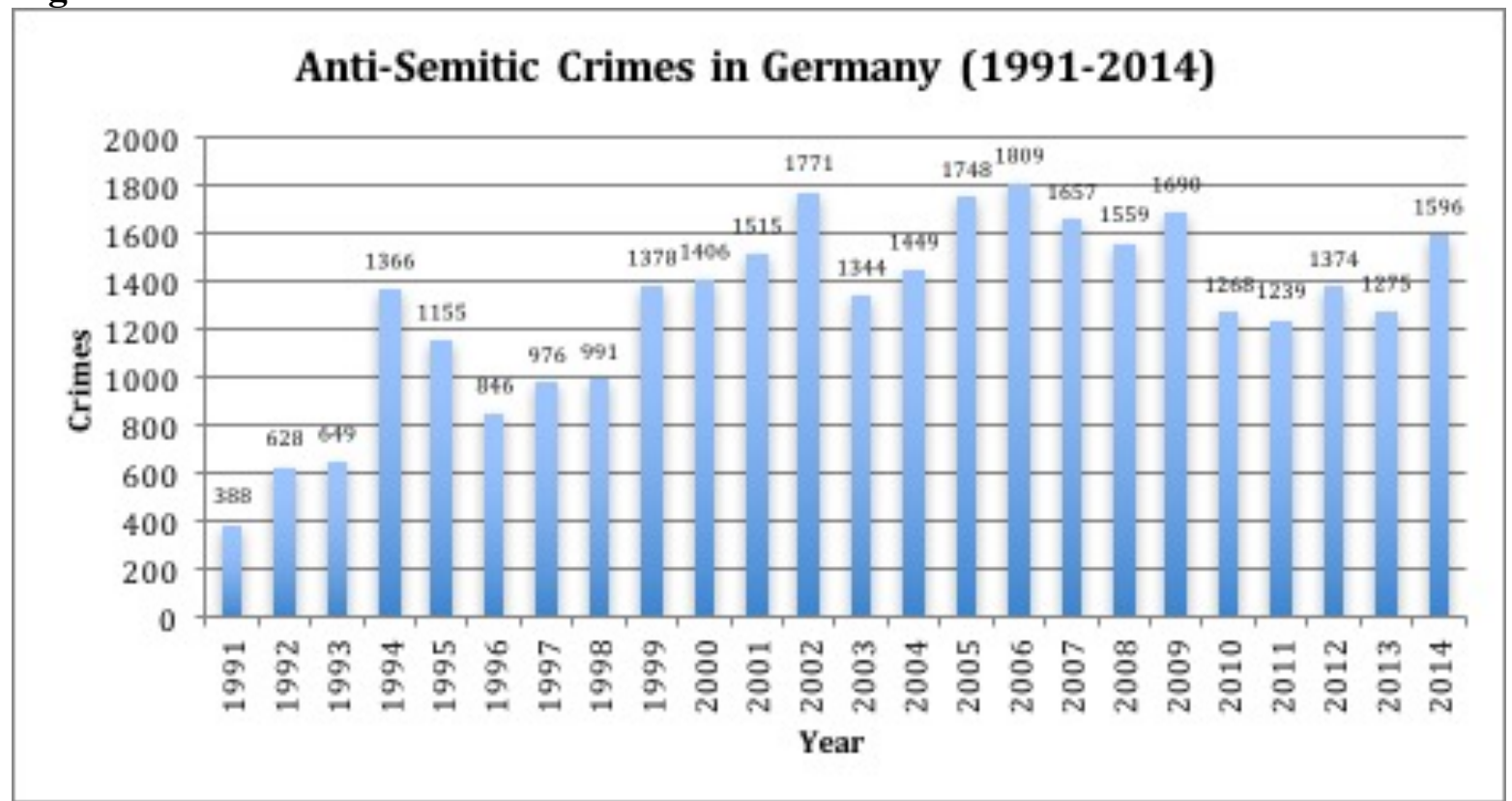

Source: German Ministry of the Interior, available at http://www.bmi.bund.de/DE/Themen/Sicherheit/Kriminalitaetsbekaempfung/Politischmotivierte-Kriminalitaet/politisch-motivierte-kriminalitaet_node.html accessed on 5 June 2016

Nonetheless, the statistics on total anti-Semitic crimes in Figure 5.6 seem to resemble those on violent attacks (Figure 5.5). Both indicators rose during the 1990's, reaching a peak in either 2006 or 2007, before an overall, but not consistent, decline in subsequent years. Similar to Figure 5.5, a rise in the domestic Jewish population, the role of external events, and an inability of state policies to consistently prevent anti-Semitic crime each serve as possible explanations for the trends revealed by the data in Figure 5.6. What this empirical evidence suggests is that while the group holding anti-Semitic views shrank in size (Figure 5.3), its motivation to engage in radical actions did not weaken.

Beyond the aggregate crime numbers, it is also important to note the perpetrators of such crimes in order to more fully understand the trends. The European Union 
Fundamental Rights Agency (EU FRA) has collected such data from Germany since 2002 and released the numbers in the agency's annual reports on anti-Semitism. Table 5.2 shows the data relating to violent anti-Semitic attacks and Table 5.3 reports the total numbers of anti-Semitic crimes committed.

Table 5.2

\begin{tabular}{|c|c|c|c|c|c|}
\hline \multicolumn{7}{|c|}{ Violent Anti-Semitic Attacks by Perpetrator (2002-2014) } \\
\hline Year & $\begin{array}{c}\text { Violent } \\
\text { Anti- } \\
\text { Semitic } \\
\text { Attacks }\end{array}$ & Right-Wing & Left-Wing & Foreigner & Other \\
\hline $\mathbf{2 0 0 2}$ & 39 & 30 & 1 & 7 & 1 \\
\hline $\mathbf{2 0 0 3}$ & 46 & 38 & 0 & 7 & 1 \\
\hline $\mathbf{2 0 0 4}$ & 45 & 40 & 1 & 3 & 1 \\
\hline $\mathbf{2 0 0 5}$ & 56 & 50 & 1 & 3 & 2 \\
\hline $\mathbf{2 0 0 6}$ & 51 & 44 & 0 & 7 & 0 \\
\hline $\mathbf{2 0 0 7}$ & 64 & 61 & 0 & 3 & 0 \\
\hline $\mathbf{2 0 0 8}$ & 47 & 44 & 2 & 1 & 0 \\
\hline $\mathbf{2 0 0 9}$ & 41 & 31 & 0 & 9 & 1 \\
\hline $\mathbf{2 0 1 0}$ & 37 & 31 & 0 & 6 & 0 \\
\hline $\mathbf{2 0 1 1}$ & 29 & 26 & 1 & 2 & 0 \\
\hline $\mathbf{2 0 1 2}$ & 41 & 37 & 0 & 4 & 0 \\
\hline $\mathbf{2 0 1 3}$ & 51 & 46 & 0 & 4 & 1 \\
\hline $\mathbf{2 0 1 4}$ & 48 & 35 & 1 & 12 & 0 \\
\hline
\end{tabular}

Source: EU Fundamental Rights Agency, Various Years, available at http://fra.europa.eu/sites/default/files/fra_uploads/fra-2015-antisemitism-update_en.pdf

The numbers in Tables 5.2 and 5.3 may differ somewhat from those in Figures 5.5 and 5.6, given that the data come from different sources. Nonetheless, the trends shown are similar, and the EU FRA data is more detailed in terms of identifying the ideological motivations behind the perpetrators of such crimes. According to the data in Table 5.2, right-wing ideologies were responsible for $87 \%$ of all violent anti-Semitic attacks between 2002 and 2014, even though the numbers of far right group membership has declined substantially over the same period. Left-wing ideologies only accounted for $1.3 \%$ of all violent attacks, and perpetrators of foreign origin account for approximately 
12\%. 2014 is a notable year, in that there was a sharp spike in the number of violent attacks committed by perpetrators of foreign origin. A likely explanation for this increase is the external events relating to the Israel-Gaza conflict, which took place in the summer of that year and sparked international controversy. Even so, right-wing ideology has accounted for the clear majority of anti-Semitic attacks each year since 2002.

Table 5.3

\begin{tabular}{|c|c|c|c|c|c|}
\hline \multicolumn{7}{|c|}{ Anti-Semitic Crimes by Perpetrator (2002-2014) } \\
\hline Year & $\begin{array}{c}\text { Anti- } \\
\text { Semitic } \\
\text { Crimes }\end{array}$ & Right-Wing & Left-Wing & Foreigner & Other \\
\hline $\mathbf{2 0 0 2}$ & 1771 & 1594 & 6 & 89 & 82 \\
\hline $\mathbf{2 0 0 3}$ & 1344 & 1226 & 6 & 53 & 59 \\
\hline $\mathbf{2 0 0 4}$ & 1449 & 1346 & 4 & 46 & 53 \\
\hline $\mathbf{2 0 0 5}$ & 1748 & 1682 & 7 & 33 & 26 \\
\hline $\mathbf{2 0 0 6}$ & 1809 & 1662 & 4 & 89 & 54 \\
\hline $\mathbf{2 0 0 7}$ & 1657 & 1561 & 1 & 59 & 36 \\
\hline $\mathbf{2 0 0 8}$ & 1559 & 1496 & 5 & 41 & 17 \\
\hline $\mathbf{2 0 0 9}$ & 1690 & 1520 & 4 & 101 & 65 \\
\hline $\mathbf{2 0 1 0}$ & 1268 & 1192 & 1 & 53 & 22 \\
\hline $\mathbf{2 0 1 1}$ & 1239 & 1188 & 6 & 24 & 21 \\
\hline $\mathbf{2 0 1 2}$ & 1374 & 1314 & 3 & 38 & 19 \\
\hline $\mathbf{2 0 1 3}$ & 1275 & 1218 & 0 & 31 & 26 \\
\hline $\mathbf{2 0 1 4}$ & 1596 & 1342 & 7 & 176 & 71 \\
\hline
\end{tabular}

Source: EU Fundamental Rights Agency, Various Years, available at http://fra.europa.eu/sites/default/files/fra_uploads/fra-2015-antisemitism-update_en.pdf

The data in Table 5.3 reflects similar trends to those in Table 5.2, in that both show that right wing ideology tends to be the predominant ideology of perpetrators of anti-Semitic crime. As previously stated, right wing perpetrators commit $87 \%$ of violent anti-Semitic attacks, and an even higher percentage of total anti-Semitic crimes at 93\%. The data indeed show that from 2010 to 2013, the number of anti-Semitic crimes tended to be lower than in previous years for most categories of perpetrator, including those of right wing ideology. Nonetheless, despite far right group membership steadily declining, 
this has not necessarily been the same trend for anti-Semitic crimes committed. 2014 stands out as a five-year highpoint in anti-Semitic crimes, and perhaps most notable is the sharp increase in crimes committed by perpetrators of foreign origin. Anti-Semitic crimes committed by those of foreign origin increased more than 500\% from 31 in 2013 to 176 in 2014. One can cite numerous potential explanations for this increase; however, most plausible is, again, perhaps the role of the Israel-Gaza conflict in the summer of that year stoking manifestations of anti-Semitism. So while opposition to Israeli policy itself may not be considered anti-Semitism, controversy surrounding the state of Israel can indeed play into anti-Semitic narratives resulting in violence or crime against even non-Israeli Jews. The data in Table 5.3 shows moderate decreases in anti-Semitic crime, particularly in the years 2010 to 2013, so one can argue that indeed state policies against antiSemitism have shown some signs of success in reducing anti-Semitic crime, but these successes are not necessarily consistent and there are other variables that can influence such trends as well.

The data in this section show that anti-Semitic violent attacks and crimes in Germany have not followed linear trends and suggest that the policies aimed to counter anti-Semitism have had mixed results. While the numbers of attacks and crimes tended to increase until 2007, these numbers have relatively, but not consistently, declined since that time. Of course, there are other variables that may also account for these trends, such as size of the domestic Jewish population and external events, but the relative declines since 2007 do nonetheless suggest that there has been moderate progress in reducing antiSemitic attacks and crime in recent years. Although right wing ideologies tend to be responsible for a vast majority of anti-Semitic incidents in Germany, the data for 
perpetrators of foreign origin tend to be especially volatile in particular years. German policies countering anti-Semitism have shown clearer trends in terms of decreasing right wing group membership and general anti-Semitic attitudes, but this has not necessarily been reflected in the crime data. A possible explanation for this is that while state policies may be successful in driving some away from anti-Semitic ideologies, they have been less successful with regard to influencing those individuals motivated enough to commit acts of violence or other crimes. Monitoring these trends further into the future will naturally provide more insight into the policy successes long-term, but as of 2016 the impacts on violent attacks and crime overall appear to be mixed and do not show as much success as in other areas.

\section{d. Jewish Perceptions and Revival}

In order to fully understand the situation for Jewish communities in Germany, it is important to look not only at the raw numbers of anti-Semitic groups, attitudes, and incidents, but also take into account the perceptions and vibrancy of the domestic Jewish population. A fundamental aspect to many of the German policies to counter antiSemitism has been to in essence rebuild much of the Jewish life in the country that had been lost to the Holocaust and persecution of Jews more generally. As explained in previous chapters, this has been attempted through various means, such as encouraging Jewish immigration, engaging Jewish groups and other NGOs, and providing funding and other support to cultural and even some religious institutions. Yet despite these efforts, as Table 5.4 shows, many German Jews continue to perceive anti-Semitism as an increasing problem in Germany. The data in Table 5.4 was collected in 2013 and reflects the 
opinions of German Jews as to whether or not they believe anti-Semitism in the country had increased or decreased over the preceding five-year period.

Table 5.4

\begin{tabular}{|l|c|c|c|c|}
\hline \multicolumn{5}{|c|}{ Perceptions of Anti-Semitism Among German Jews, 2008-2013 } \\
\hline & $\begin{array}{c}\text { \% Has } \\
\text { increased }\end{array}$ & $\begin{array}{c}\text { \% Stayed } \\
\text { the same }\end{array}$ & $\begin{array}{c}\text { \% Has } \\
\text { decreased }\end{array}$ & $\begin{array}{c}\text { \% Do not } \\
\text { know }\end{array}$ \\
\hline Anti-Semitism in general & 68 & 23 & 5 & 4 \\
\hline $\begin{array}{l}\text { Anti-Semitism in the } \\
\text { media }\end{array}$ & 48 & 34 & 8 & 10 \\
\hline $\begin{array}{l}\text { Anti-Semitism in political } \\
\text { life }\end{array}$ & 37 & 41 & 9 & 12 \\
\hline $\begin{array}{l}\text { Anti-Semitism on the } \\
\text { internet }\end{array}$ & 64 & 16 & 3 & 16 \\
\hline Anti-Semitic graffiti & 26 & 46 & 8 & 21 \\
\hline $\begin{array}{l}\text { Desecration of Jewish } \\
\text { cemeteries }\end{array}$ & 30 & 46 & 10 & 15 \\
\hline $\begin{array}{l}\text { Vandalism of Jewish } \\
\text { buildings or institutions }\end{array}$ & 28 & 46 & 9 & 9 \\
\hline $\begin{array}{l}\text { Expressions of hostility } \\
\text { towards Jews in the street } \\
\text { or other public places }\end{array}$ & 57 & 28 & 5 & \\
\hline
\end{tabular}

Source: EU Fundamental Rights Agency, 2013, available at http://fra.europa.eu/en/publications-and-resources/data-and-maps/survey-data-explorerdiscrimination-and-hate-crime-against

Even as anti-Semitic crimes decreased by $18 \%$ over this period (Federal Office for Protection of the Constitution, Various Years) and anti-Semitic attitudes decreased by 12\% from 2008 to 2012 (Decker, 2014), 68\% of German Jews still had the perception that general anti-Semitism was an increasing problem in the country. In fact, a majority of German Jews either believed that anti-Semitism had increased or stayed the same for every category measured as part of the EU Fundamental Rights Agency survey. These results indicate that while German policies may have reduced anti-Semitic indicators in some areas, such as right wing group membership and general anti-Semitic attitudes, 
many Jews continue to believe that expressions of hostility and anti-Semitism in general have increased, at least during the time period measured.

There have, nonetheless, been some indications of a Jewish revival in the country since 1990, despite the reported negative perceptions among many German Jews. Since 1990, Germany has become home to the world's fastest growing Jewish population (Crossland, 2012). This is in part due to the country's loosening of immigration law for Jewish immigrants - 90\% of German Jews are, in fact, immigrants (Ben-Rafael, 2015: 57). In 1990, there were fewer than 30,000 Jews in Germany, but, as of 2012, there were over 100,000 who belonged to Jewish religious communities, and a total population with a Jewish background estimated to be over 200,000. Included in these increases are some 20,000 Israeli Jews who have immigrated to Germany (Crossland, 2012). These increases mean that Germany, as of 2015, has not only the fastest growing, but also the third largest Jewish population in Europe following France and the United Kingdom (Ben-Rafael, 2015: 59).

With the increases in Germany's Jewish population, the number of Jewish institutions and representations of the religion have also been on the rise within a number of German cities. Since 1990, the number of synagogues in Germany has risen from only a handful to 130 as of 2015 (Deutsche Welle, 2015). While this number is still far less that the 2,800 synagogues that were in the country in 1933 , there has nonetheless been a notable increase since German reunification. Cities, such as Mainz, Dresden, Essen, and others, whose synagogues were either destroyed or heavily damaged by the Nazis or fighting in World War II have only since 2000 had these structures rebuilt (ibid.). 
One city that perhaps best represents the revival of Jewish life in contemporary Germany is the Eastern German city of Leipzig. Leipzig historically had one of the most active Jewish populations on German lands since at least the thirteenth century, as it served as a central location for Jewish traders throughout Europe. In 1935, Leipzig's Jewish community consisted of some 11,500 members, making it the sixth largest Jewish community in Germany at the time. But by February 1945, all Jews in the city had either emigrated or were killed or deported (Virtual Jewish Library, 2008). In the following decades, Leipzig's Jewish community was virtually non-existent with a total of only 30 reported members in 1989. However, largely through increased immigration from the former Soviet Union, the city's Jewish community increased to some 1,300 members by 2010 (Deutsche Welle, 2010). The majority of Leipzig's Jews are indeed immigrants, as are the city's leading rabbis who immigrated from Lithuania and Uzbekistan (ibid.). As has been mentioned, 90\% of Germany's contemporary Jewish community are immigrants, so the revival in Leipzig is indeed a reflection of the growth in Jewish communities across the country. And although $68 \%$ of German Jews in the EU Fundamental Rights Agency survey perceived anti-Semitism as an increasing problem in the country, Germany has remained an attractive destination for many Jewish migrants worldwide. One potential explanation for this is that Jews outside Germany may perceive anti-Semitism in Germany to be less of a problem than they are likely to face elsewhere. There may also be additional economic and social reasons that tend to attract Jewish migrants to Germany beyond simply perceptions of anti-Semitism. Nonetheless, Jewish migration to Germany has in many cities led to a revival of Jewish culture and religion. 
In order to serve these growing Jewish communities throughout the country, both Jewish organizations and even the German government have placed an emphasis on bolstering the country's theology schools to train a greater number of rabbis domestically. In 2013 , on the $75^{\text {th }}$ anniversary of Kristallnacht, the University of Potsdam opened the first state-funded Jewish theology school in Europe. At the school's opening, German President Joachim Gauck stated, "In Germany, of all places, where the Jewish intelligentsia ... was expelled and murdered, Jewish theology is finally being given its proper role" (Ferber, 2014). The theology school opened with fifty students and six newly appointed professors focusing on the subjects of Jewish liturgy and history. An important motivation behind opening the school has been to help put Judaism in Germany on equal footing with Christianity and Islam, in order to both help revive the religion within the country and create new opportunities for interfaith dialogue (ibid.). In addition to the opening of new synagogues, Jewish cultural institutions, and an increasing Jewish population, the country's first modern school of Jewish theology is an important marker in the country's wider Jewish revival.

\section{Conclusion}

The data from the German case indicates that the state policies employed to counter anti-Semitism in the country have had greater effectiveness in some areas than others. As mentioned in previous chapters, many of the German legal and public diplomacy responses have targeted far right groups, in large part due to the fact that such groups commit an overwhelming majority of anti-Semitic crimes and violent attacks. The data indicate that these policies have largely been effective in terms of reducing far right group membership, as membership in such groups fell approximately two-thirds from the 
early 1990 's to 2014 . Nonetheless, far right party support has increased in certain states, such as Mecklenburg-Vorpommern and Saxony, although such support decreased in the most recent elections in both states. Nationally, the two main far right parties, the NPD and die Republikaner, have obtained less than $2.5 \%$ of the votes cast in Bundestag elections since reunification. So while far right group membership as a whole has decreased, support for far right political parties has not necessarily followed the same trend.

Survey data indicate that anti-Semitic attitudes have consistently fallen in Germany since 2002. Generally, the data shows that anti-Semitic attitudes have been more prevalent in Western Germany, although the results in Eastern Germany tend to be more volatile over time. These data indicate that policies toward anti-Semitism have been relatively effective in terms of decreasing general anti-Semitic attitudes within the country. However, whereas anti-Semitic attitudes have declined over time, xenophobic attitudes have tended to be more prevalent, especially in Eastern Germany. These data are important considering that $90 \%$ of German Jews are immigrants. Therefore, members of Germany's Jewish community may potentially face hostility for either reason and one may not be able to always decipher the precise motivation in such cases. So while antiSemitic attitudes may have decreased in the country since 2002 , the prevalence of xenophobic attitudes in the country also pose a threat to the domestic Jewish community's well-being.

Anti-Semitic crimes and violent attacks regularly increased in Germany from 1991 to 2007, but have tended to decrease in recent years. There are a few possible explanations for these trends. First, large increases in Germany's Jewish population led to 
more anti-Semitic attacks and crimes, in part because there were simply more Jews who could potentially become targeted for such acts. Second, external events may at times stoke anti-Semitic attitudes and behavior, thus lead to a higher number of attacks and crimes. And third, state policies countering anti-Semitism may not have been consistently successful in preventing attacks or influencing potential perpetrators. The data also demonstrate that far right ideologies and groups tend to be responsible for the vast majority of anti-Semitic attacks and crimes. Right wing groups were responsible for $87 \%$ of anti-Semitic violent attacks and $93 \%$ of all anti-Semitic crimes. At the same time, the number of crimes and attacks committed by foreigners has shown to be volatile and reached a high point in 2014. These data indicate that since 2007 state policies against anti-Semitism may have had moderate effects on the number of anti-Semitic violent attacks and crime, but these results have not been as pronounced as in other areas, such as the drastic decreases in far right group membership.

Even as indicators of anti-Semitism have decreased in recent years, $68 \%$ of German Jews perceive that anti-Semitism in general is increasing. So while state policies against anti-Semitism have demonstrated effectiveness in some areas, a majority of the country's Jewish population reports increasing levels of hostility in public places. Nonetheless, Germany has since 1990 had the world's fastest growing Jewish population. Germany's Jewish population has more than tripled over this period of time. Consequently, the country has shown signs of a Jewish revival since reunification with increases in not only population, but also the number of Jewish religious, cultural, and educational institutions. These factors indicate that while many German Jews report antiSemitism as an increasing problem, Germany also remains an attractive destination for 
many Jews worldwide. The next chapter will evaluate the effectiveness of similar policies

in Poland and help draw comparisons to these findings in the German case.

\section{References}

Ben-Rafael, Eliezer (2015). Germany's Russian Speaking Jews, in Being Jewish in $21^{\text {st }}$ Century Germany, (eds.) Olaf Glöckner and Haim Fireberg. Berlin: de Gruyter.

Crossland, David (2012). We Can Resume Our Common History: New Paper Covers Revival of German Jewish Life, Der Spiegel. 4 January, http://www.spiegel.de/international/germany/we-can-resume-our-commonhistory-new-paper-covers-revival-of-german-jewish-life-a-807118.html, accessed on 7 September 2016.

Decker, Oliver, Johannes Kiess and Elmar Brähler (2014). Die Stabilisierte Mitte Rechtsextreme Einstellung in Deutschland 2014. Leipzig: University of Leipzig, $\mathrm{http} / / /$ research.uni-leipzig.de/kredo/Mitte_Leipzig_Internet.pdf accessed on 5 June 2016.

Deutsche Welle (2010). Mainz Synagogue Highlights Revival of Jewish Life in Germany, 9 April, http://www.jewishvirtuallibrary.org/jsource/judaica/ejud_0002_0012_0_12095.ht $\mathrm{ml}$, accessed on 8 September 2016.

Deutsche Welle (2015). Synagogues in Germany. http://www.dw.com/en/synagogues-ingermany/g-18208619, accessed on 8 September 2016.

EU Fundamental Rights Agency (Various Years). Antisemitism: Overview of Data Available in the European Union, http://fra.europa.eu/sites/default/files/fra_uploads/fra-2015-antisemitismupdate_en.pdf, accessed on 28 May $201 \overline{6}$.

EU Fundamental Rights Agency (2013). Survey Data Explorer - Discrimination and Hate Crime against Jews in EU: Experiences and Perceptions of Antisemitism, http://fra.europa.eu/en/publications-and-resources/data-and-maps/survey-dataexplorer-discrimination-and-hate-crime-against, accessed on 4 June 2016.

Federal Office for Protection of the Constitution (Various Years). Annual Report from the Federal Office for Protection of the Constitution (Verfassungsschutzbericht), https://www.verfassungsschutz.de/de/oeffentlichkeitsarbeit/publikationen/verfass ungsschutzberichte, accessed on 2 June 2016. 
Ferber, Alona (2014). Historical Milestone: Theology School Symbol of Revival of Jewish Life, Der Spiegel, 20 February:

http://www.spiegel.de/international/germany/german-jewish-theology-schoolsymbolizes-revival-of-judaism-a-954599.html, accessed on 8 September 2016.

German Ministry of the Interior (Various Years). Annual Report on Politically Motivated Crime (Politische Motivierte Kriminalität), http://www.bmi.bund.de/DE/Themen/Sicherheit/Kriminalitaetsbekaempfung/Polit isch-motivierte-Kriminalitaet/politisch-motivierte-kriminalitaet_node.html accessed on 5 June 2016.

Jewish Community of Berlin (2016). "Integration," http://www.jg-berlin.org/en/institutions/integration.html, accessed on 16 February 2016.

Jikeli, Günther (2015). Antisemitic Attitudes among Muslims in Europe: A Survey Review, Institute for the Study of Global Antisemitism and Policy, May: http://isgap.org/wpcontent/uploads/2015/05/Jikeli_Antisemitic_Attitudes_among_Muslims_in_Euro pe1.pdf, accessed on 7 June 2016 .

Klusmeyer, Douglas and Demetrios Papademetriou (2013). Immigration Policy in the Federal Republic of Germany. New York: Berghahn.

Niedermayer, Oskar (2016). Parteimitglieder in Deutschland: Version 2016, Freie Universität Berlin: http://www.polsoz.fuberlin.de/polwiss/forschung/systeme/empsoz/schriften/Arbeitshefte/P-PM16NEU.pdf, accessed on 27 October 2016.

Pew Research Center (2006). Global Attitudes and Trends, http://www.pewglobal.org/category/datasets/2006/?download=12029, accessed on 7 June 2006.

Virtual Jewish Library (2008). Virtual Jewish World: Leipzig, Germany, http://www.jewishvirtuallibrary.org/jsource/judaica/ejud_0002_0012_0_12095.ht $\mathrm{ml}$, accessed on 9 September 2016.

Wahlrecht.de (2016). Election Results, http://www.wahlrecht.de/ergebnisse/index.htm accessed on 3 June 2016. 


\section{CHAPTER VII}

\section{EVALUATING THE EFFECTIVENESS IN POLAND}

The goal of this chapter will be to empirically evaluate the effectiveness of the state policies toward anti-Semitism in contemporary Poland. The data used to evaluate the effectiveness of these policies include: support for far right parties/groups; levels of anti-Semitic attitudes and hate crimes; and the vibrancy of the domestic Jewish community. Each of these indicators helps to evaluate the success of the state policies explained in previous chapters by demonstrating trends over time. In analyzing such data, one is able to develop a better understanding of the areas where these policies have been most and least effective. Particularly important to note is whether there have been changes in the data after the policy was adopted. As explained in previous chapters, the first policies implemented were the legal measures introduced with the adoption of the country's constitution and penal code of 1997. The public diplomacy initiatives in Poland were implemented in two parts. First, Poland focused on correcting mischaracterizations of the country's history with the adoption of the 'Framework Program' in 2002. Later, these efforts were expanded and began to include a more direct emphasis on domestic engagement beginning in 2005. This timeline of policy implementation will be essential with regard to the analysis in this chapter.

\section{a. The Influence of Far Right Groups}

As mentioned in the previous chapter, German policies toward anti-Semitism have shown effectiveness with regard to decreasing the membership and influence of far right groups in the country over time. In Poland, the policies developed to counter antiSemitism have been less focused on such groups. Although Poland's Human Rights 
Protection Team did monitor hate crimes in the country, the Polish government does not track membership statistics for far right nor anti-Semitic groups. This makes it difficult to directly compare the size and influence of such groups in these two countries over time. Nonetheless, one area where a more direct comparison can be made is in the realm of electoral politics. While Poland does not have reliable statistics for total far right and anti-Semitic group membership, election results in the country provide some indications of the influence and support for groups with such ideology.

Poland has a few parties that emphasize an anti-Semitic ideology, including the National Rebirth of Poland (NOP - registered in 1992), National Radical Camp (ONR registered in 1993), and the Polish National Party (PNP - registered in 2004). These parties, while known for their media campaigns, have not consistently run candidates for parliamentary nor regional elections. In fact, none of these parties have received above $0.3 \%$ of the vote in any parliamentary election since their founding - far short of the $5 \%$ threshold needed to attain representation in the Sejm or Senat. The most electorally successful year for anti-Semitic parties in Poland was 2005, in which the PNP received 34,127 total votes $(0.29 \%)$ and the National Rebirth of Poland received 7,376 total votes $(0.06 \%)$. None of these parties have appeared on national parliamentary ballots since that time (National Electoral Commission of Poland, 2016).

These data suggest that parties with an overt anti-Semitic ideology tend to be less successful in Polish electoral politics than similar parties in Germany. Nonetheless, there are segments in other nationalist parties that have expressed anti-Semitic views, although these views are not necessarily embraced by the party as whole. This is particularly the case with more nationalistic parties, which often ascribe to a Catholic nationalist 
ideology. For example, Polish Defense Minister and Deputy Leader of the Law and Justice (PiS) party, Antoni Macierewicz, has expressed his belief that the Jewish conspiracy laid out in The Protocols of the Elders of Zion could be real. Macierewicz told a listener during a 2002 Radio Maryja interview that "experience shows that there are such groups in Jewish circles" when asked about the conspiracy (Syal, 2015). Another member of Law and Justice, Senator Dorota Arciszewska-Mielewczyk, controversially stated that "Polish Jews are represented by the Knesset and not the Polish parliament" in January 2014 in response to a report on anti-Semitism that was delivered to the Polish parliament (Coordination Forum for Countering Anti-Semitism, 2014). These statements demonstrate that while overtly anti-Semitic parties in Poland may not achieve widespread electoral success, there are indeed elements within, particularly nationalist parties, that have expressed anti-Semitic beliefs.

Given the lack of reliable data on far right and anti-Semitic groups in Poland, it is difficult to fully evaluate the extent that policies toward anti-Semitism have had on these groups over time. Those overtly anti-Semitic groups that have been organized and registered as political parties tend to be rather minor and have not achieved significant success in modern elections. However, this does not necessarily mean that general antiSemitic attitudes are at a lower level in Poland, only that anti-Semitic ideology has not been particularly influential as an organized, distinct movement in Polish politics. Those leaders who have expressed anti-Semitic beliefs have tended to be within nationalist elements of other major parties that do not necessarily have anti-Semitism as a core tenet of their platform, thus making them more difficult to identify as a distinct, organized group. This lack of clearly defined, popular anti-Semitic and far right groups in Poland 
makes it more difficult to target policies toward such groups, as is often done in the German case. In order to achieve a better understanding of the results in Poland, it may be more beneficial to examine more general survey data on anti-Semitic attitudes, which tend to be more frequently collected and reliable.

\section{b. Anti-Semitic Attitudes}

The data most consistently collected in Poland with regard to anti-Semitism since the end of communist rule has been attitude surveys. Since 1993, the Public Opinion Research Center based in Warsaw has collected annual survey data on the sympathy and antipathy among Poles toward Jews. These data are displayed in Figure 6.1.

Figure 6.1

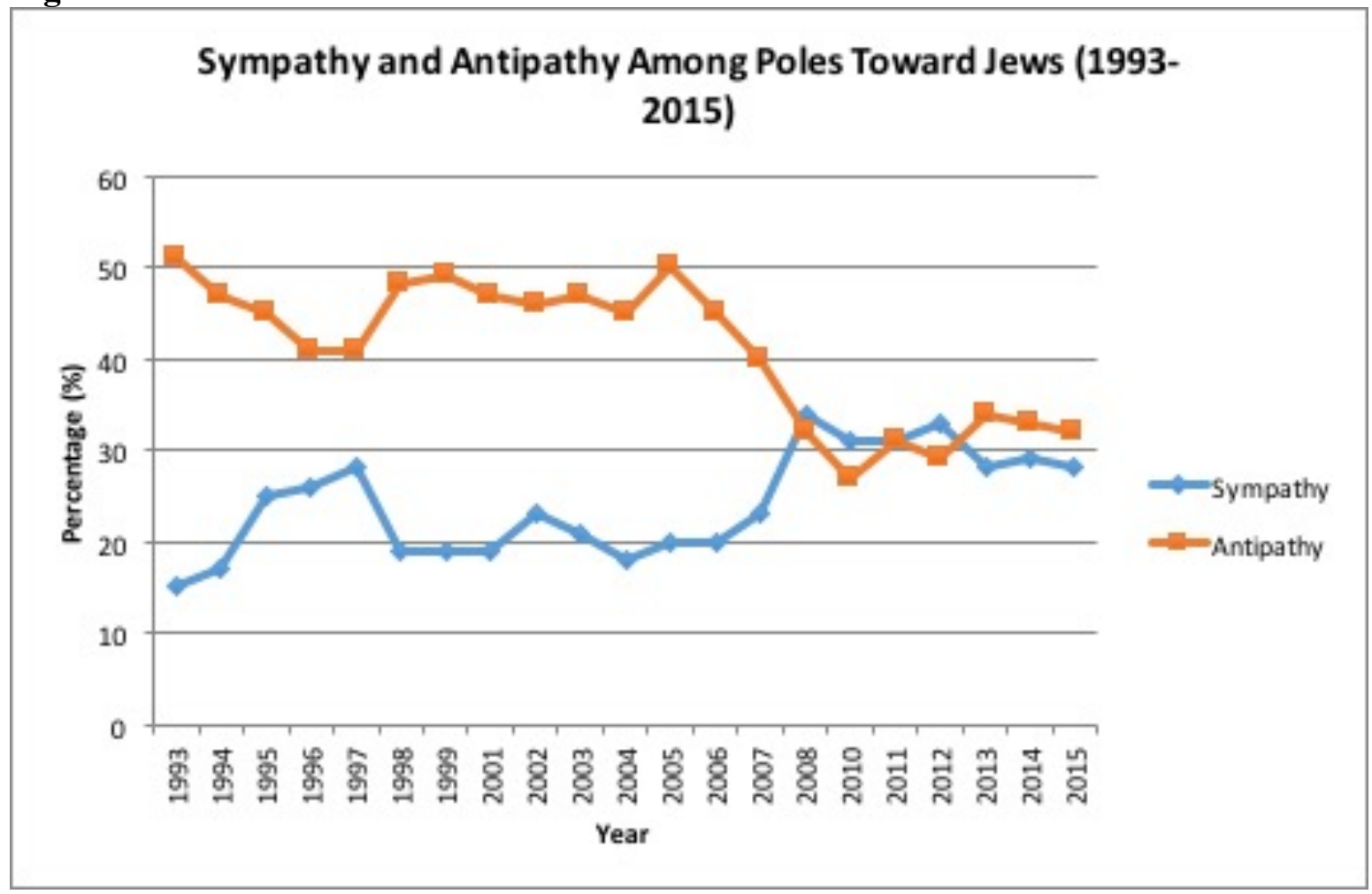

Source: Public Opinion Research Center, available at http://www.cbos.pl/SPISKOM.POL/2015/K_014_15.PDF 
As the data show, sympathy toward Jews was lowest among Poles in the first year for which data was collected (1993) at only 15\%, while antipathy was also at its highest level in the same year at over $50 \%$. With a few exceptions, the data remained relatively consistent until about 2005 when sympathy began to increase and antipathy began to decrease. This change is especially notable, because this is the time period in which many of Poland's policies to counter anti-Semitism had become fully implemented. As noted in previous chapters, Poland's legal response to anti-Semitism began in 1997 with the adoption of the country's constitution and penal codes, both of which include punishments for hate crimes against Jews and other groups based on nationality, ethnicity, race, or religion. However, there was little to no immediate impact on Polish attitudes toward Jews in the years following the adoption and implementation of these laws. In fact, attitudes toward Jews tended to become more negative in the years following 1997 (sympathy dropped by about 10\% in 1998). One possible explanation for this is that these legal measures were more intended to prevent expressions of violence against Jews than attitudes specifically. These legal measures were largely intended to provide a deterrent to those who may commit acts of violence or promote hateful speech, and less to change the attitudes of those who may not act violently, but yet have antipathy toward Jews.

Another aspect of Poland's legal response was the establishment of the Institute for National Remembrance (IPN), which was founded in 1998 and began operation in 2000 (Institute for National Remembrance, 2017). It is important to remember that the IPN is not merely limited to prosecuting crimes relating to Nazism and communism, but also determining the facts with regard to Nazi and communist crimes, such as the 
Holocaust. These latter tasks are carried out through the Bureau of Provision and Archivization of Documents, so while the IPN is indeed a part of Poland's legal response to anti-Semitism, it also engages in debates and corrects misinformation about a number of groups, including Jews, and the crimes committed against them. In this way, one may consider the IPN as an organization that straddles the lines between the legal and public diplomacy responses, as the organization is engaged in both the prosecution of hate crimes and influencing public opinion and knowledge. As the data show, the IPN did not have an immediate effect on Polish attitudes toward Jews in the five years following its establishment in 2000. However, the sorts of historical research and educational goals of the organization are likely to take time to develop, so one may expect these measures not to have immediate impacts on public opinion, it is possible, however, that such measures have made an impact in the long term.

The most noticeable declines in antipathy toward Jews and increases in sympathy toward Jews began after 2005. While it is true that Poland's public diplomacy campaign had its roots in 2002 with the establishment of the Framework Program, these early initiatives were primarily concerned with correcting mischaracterizations abroad in order to gain support for Polish accession to the EU. It was not until 2005, after Poland had achieved EU accession, that the public diplomacy initiatives became more internally focused. This internal focus included the promotion of Jewish cultural events, educational initiatives, dialogical forums, and greater outreach to Jewish communities. It is indeed noteworthy that the most pronounced shift with regard to positive attitudes toward Jews began shortly after the implementation of such programs. In 2005, approximately $50 \%$ of Poles had antipathy toward Jews, but by 2010 this number was reduced by nearly half to 
$27 \%$. It is also worth noting that 2008 was the first time recorded in which Poles had more sympathy toward Jews than antipathy. Since that time, levels of sympathy and antipathy have been relatively even, whereas in most years prior to the public diplomacy campaign the levels of antipathy toward Jews were nearly twice the levels of sympathy. This chronology suggests that the implementation of a domestically focused public diplomacy campaign led to more positive attitudes among Poles toward Jews.

These assertions are reflected in other survey research covering the same period as well. In 2002, before the public diplomacy components focusing on domestic factors were fully implemented, $20 \%$ of Poles believed that Jews were responsible for conspiring to negatively influence Polish politics. That figure was reduced to only $6 \%$ by 2011 (Borger and Vasagar, 2011). In 2002, 43\% of Poles said that Jews have too much influence within Polish society; that number was decreased to 22\% by 2010 (Sulek, 2012). Perhaps most encouraging for the future of Poland's domestic environment, survey data from 2008 showed that levels of anti-Semitism among Polish youth are quite low. According to Ireneusz Krzeminski's scale of modern anti-Semitism, only 5\% of 17 18-year-old Polish students held strongly anti-Semitic beliefs whereas 27\% of Polish adults held such beliefs (Ambrosewicz-Jacobs, 2013).

Measuring more general perceptions toward discrimination, Eurobarometer collected survey data in 2012 that suggests Poles tend to view discrimination as less of a problem in their country than the EU average. As Table 6.1 shows, only $21 \%$ of Poles view religious discrimination as a widespread domestic problem compared to $39 \%$ for the EU as a whole (Eurobarometer, 2012). 
Table 6.1

\begin{tabular}{|l|l|l|l|l|}
\hline \multicolumn{5}{|c|}{ Perceptions of Religious Discrimination (2012) } \\
\hline & Widespread & Rare & Non-Existent & Do Not Know \\
\hline EU & 39 & 51 & 5 & 5 \\
\hline Poland & 21 & 57 & 14 & 8 \\
\hline
\end{tabular}

Source: Eurobarometer, available at

http://ec.europa.eu/public_opinion/archives/ebs/ebs_393_fact_pl_en.pdf

Similarly, when asked the question "Using a scale from 1 to 10, how would you feel about having someone of a different religion than the majority of the population in the highest political position in your country? 1 means that you would feel 'very uncomfortable' and 10 means you would feel 'very comfortable,'” the average Pole answered 8 compared to 6.7 for the EU as a whole (ibid.). When asked whether or not the expression of one's religious beliefs, such as wearing a visible religious symbol, would negatively affect one's employment prospects, only 9\% of Poles answered "yes" compared to $23 \%$ for the EU average (ibid.). It is worth noting that this data was collected to measure Polish public opinion generally, and not necessarily represent the views of religious minority groups, who would most likely be the target of discrimination. So while such data do not necessarily demonstrate that religious discrimination is less of a problem in Poland than the EU generally, the data does suggest that Poles tend to view their country as more tolerant.

Although sympathetic attitudes toward Jews have generally increased in Poland since the 1990's, recent data has shown increases in particular strains of anti-Semitism, particularly religious and economic anti-Semitism. Figures 6.2 and 6.3 show survey data from 2009 and 2013 regarding two of the most common beliefs in religious antiSemitism - Jewish responsibility for the death of Jesus Christ and accusations of blood libel. 


\section{Figure 6.2}

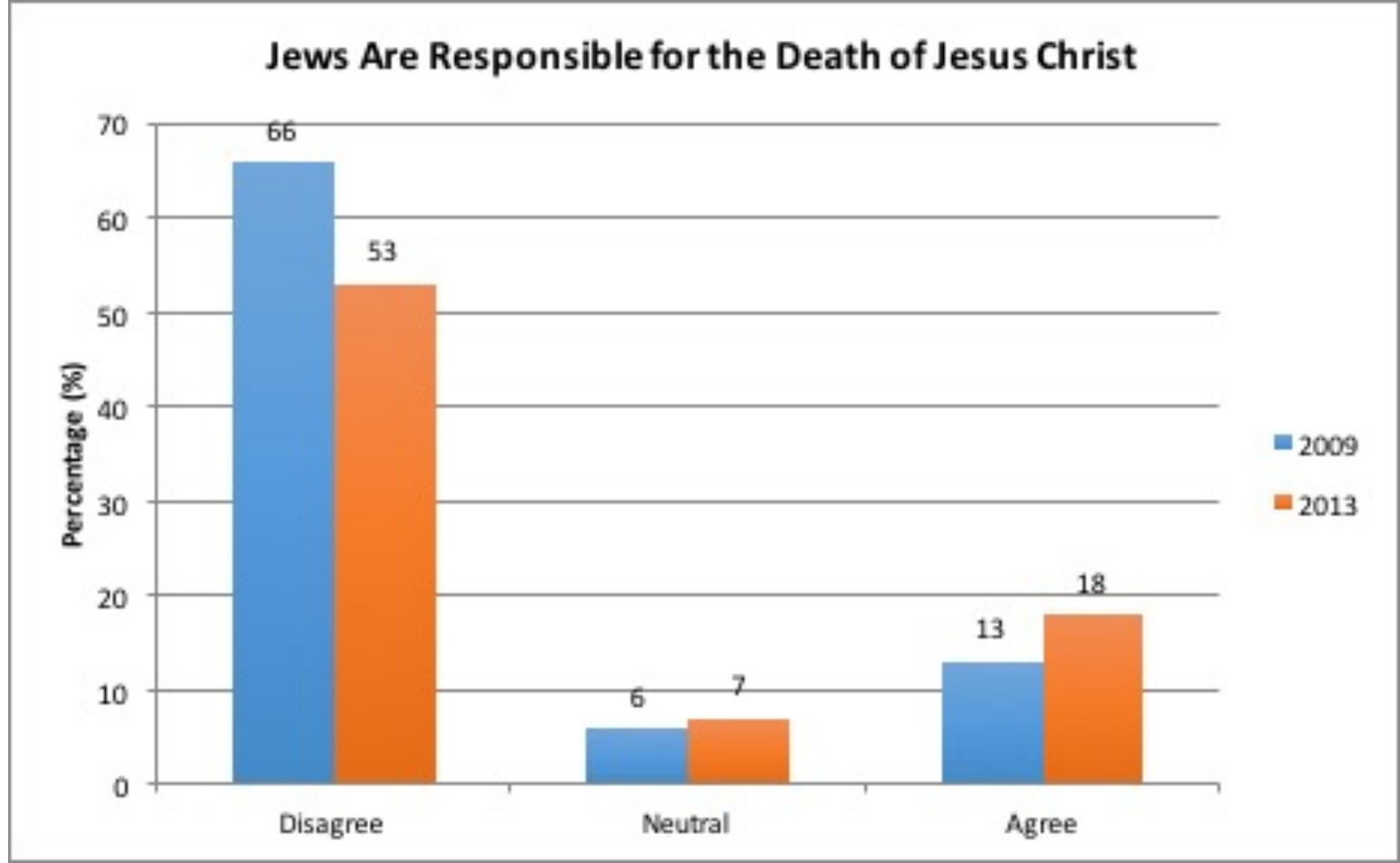

Source: Center for Research on Prejudice, available at http://cbu.psychologia.pl/uploads/f_winiewski/PPS2\%20raporty/raport_antysemityzm_an g.pdf

While a majority of Poles disagree with the statement that Jews are responsible for the death of Christ, the data show that the anti-Semitic belief in deicide had greater resonance in 2013 than in 2009 . Whereas $66 \%$ disagreed with the claims in 2009 , only $53 \%$ disagreed in 2013 . And whereas only $13 \%$ believed such claims in 2009 , that number increased to $18 \%$ in 2013 . These data do not, however, necessarily contradict the data in Figure 6.1, which did show an approximately 5\% increase in antipathy toward Jews from 2010 to 2013.

Figure 6.3 demonstrates that belief in blood libel also increased from 2009 to 2013. 


\section{Figure 6.3}

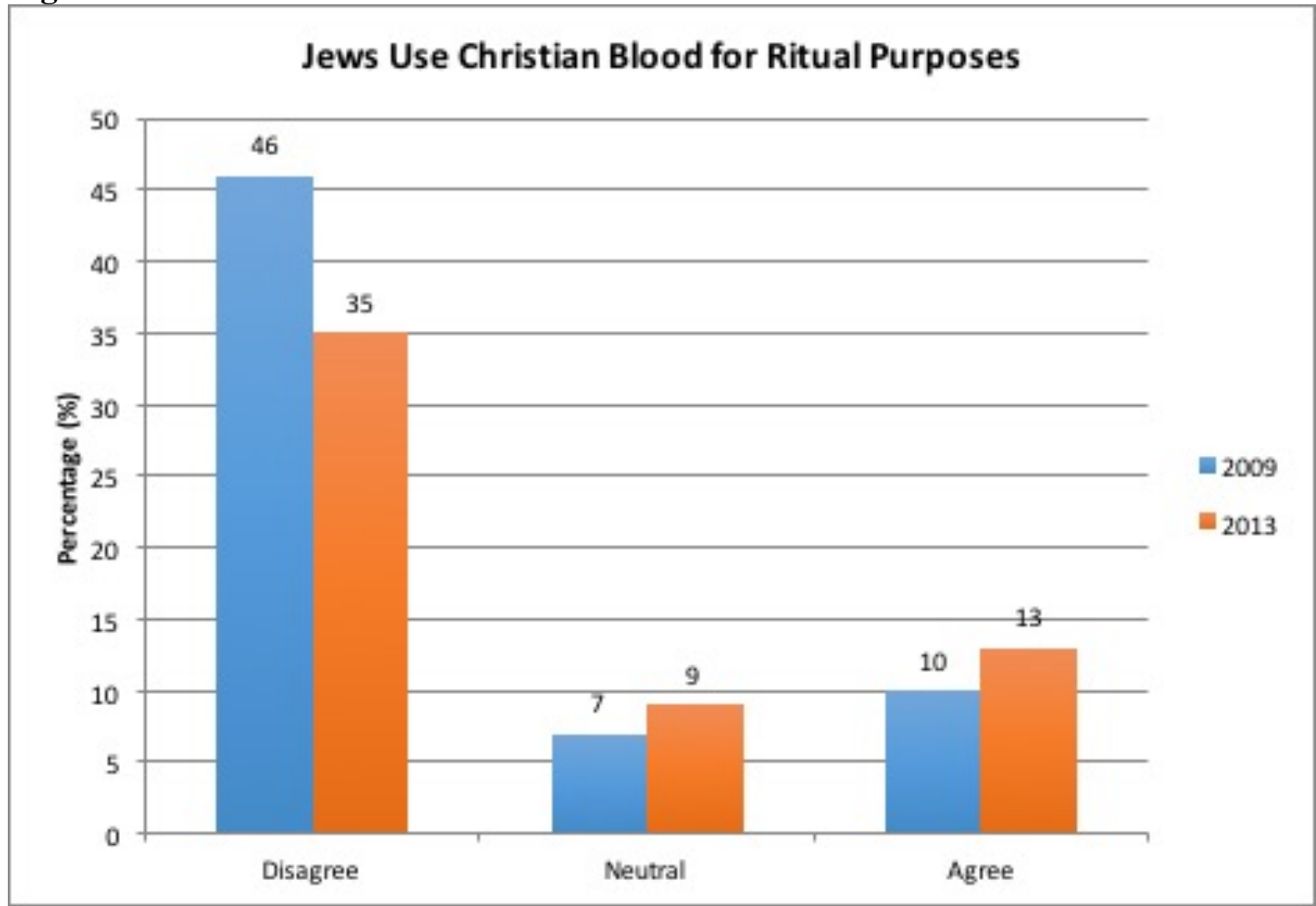

Source: Center for Research on Prejudice, available at

http://cbu.psychologia.pl/uploads/f_winiewski/PPS2\%20raporty/raport_antysemityzm_an g.pdf

Whereas $46 \%$ of Poles in 2009 disagreed with the claim that Jews use Christian blood for ritual purposes, only $35 \%$ disagreed with such a statement in 2013 . The number who agreed increased from $10 \%$ in 2009 to $13 \%$ in 2013 . These data indicate that although general attitudes regarding sympathy and antipathy toward Jews have improved since the 1990's, there are still elements of anti-Semitism that remain prevalent and have even increased in recent years. The periods measured in Figures 6.2 and 6.3 are after the most prominent legal and public diplomacy measures combatting anti-Semitism were implemented, so these data suggest that the policies were not entirely effective in reducing certain strains of anti-Semitism, in this case religious anti-Semitism. While the 
legal measures implemented in the 1990's do provide punishments for anti-Semitic behavior, these measures are not necessarily designed to directly influence attitudes. Influencing attitudes is more in the domain of the public diplomacy responses, which have shown some effectiveness in terms of reducing antipathy toward Jews, but have not necessarily been as effective in reducing the prevalence of certain religiously anti-Semitic myths.

Another strain of anti-Semitism that has long existed in Poland, as it has elsewhere, is that of economic anti-Semitism. As explained in earlier chapters, ever since their arrival in Poland in the tenth century, Jews have played an integral role in the development of the Polish economy. Educated Jews from neighboring lands who faced persecution were often invited by Polish kings for their expertise in obtaining capital and financial resources to develop industry and agriculture. However, the relative success of many Jews in the Polish economy contributed to a feeling of grievance and resentment among some Poles. These grievances were exploited throughout history, especially during the twentieth century by the National Democratic Party in the 1920's and 1930's, the Nazis during their occupation of Poland, and the post-war communist government led by the Soviet Union. Jews had often been cited as a scapegoat to deflect attention from each of these regimes' numerous failures. This deep rooted history of economic antiSemitism perpetuated for generations by various governments would seem difficult to counter.

One may assume that as Poland has improved its economy since the fall of communism in 1989, economically-driven anti-Semitism would decline; yet, the data in Figure 6.4 show that this does not seem to be the case. The number of Poles who agree 
with the statement that "Jews have too much economic influence" has increased in most years measured from 1992 to 2011.

Figure 6.4

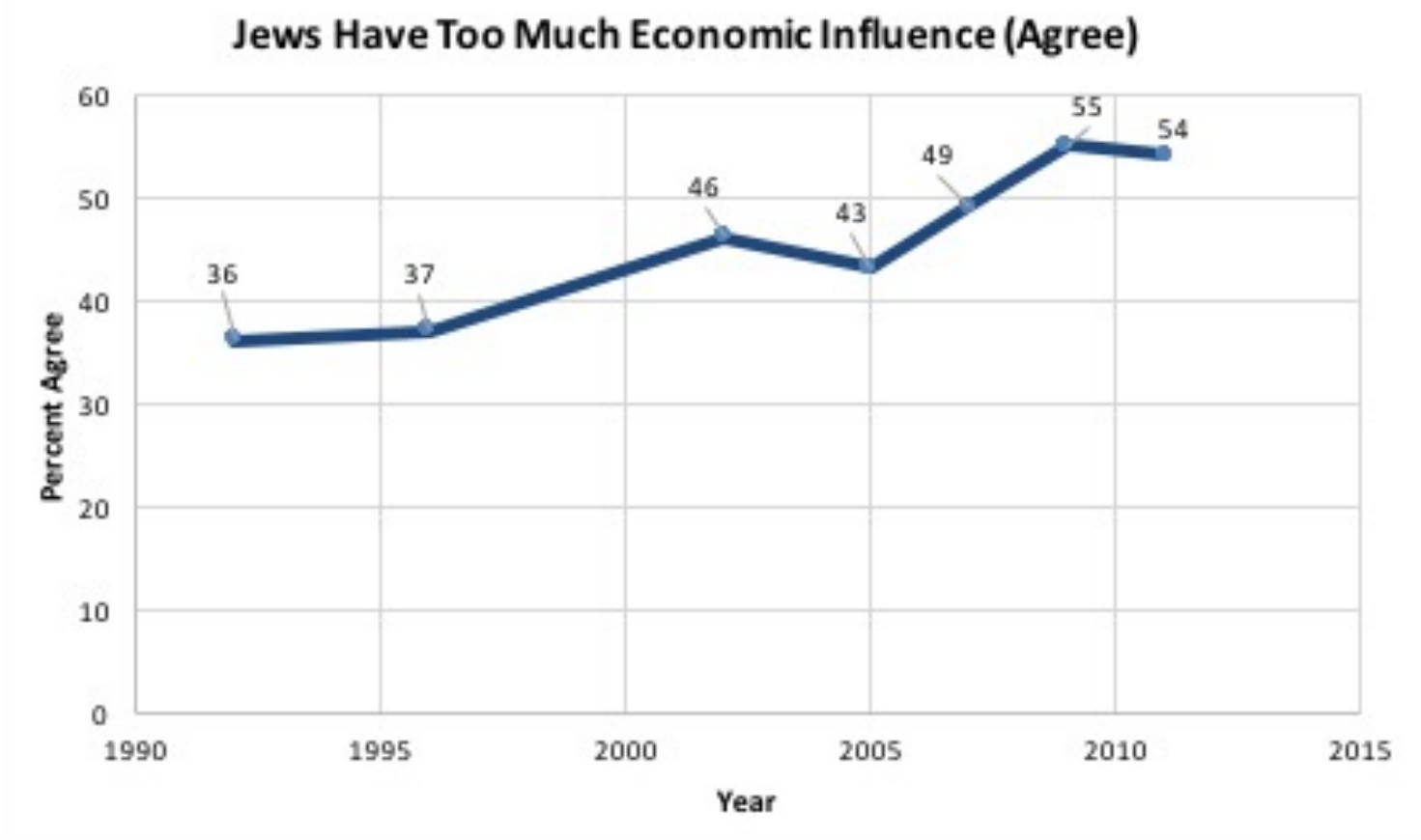

Source: Bilewicz, 2012

Of the years measured, 1992 had the lowest level of those asserting economically antiSemitic attitudes at $36 \%$ and rising to $55 \%$ in 2009 . One may expect that the economic hardships related to the shock therapy approach to marketization and liberalization of the Polish economy in the 1990's would have triggered more negative attitudes toward Jews in terms of their economic influence. As data before 1992 is unavailable, it is not possible to fully examine this hypothesis, but the data in Figure 6.4 does show that economic antiSemitism did indeed increase in the 2000's - even after market liberalization was largely accomplished. It is also worth noting that the periods from 2005-2007 and 2007-2009 each experienced rather large 6\% increases in economic anti-Semitism. From 2005-2007, the government was controlled by the more right-wing, national-conservative Law and 
Justice party, and, from 2007-2009, the government was controlled by the more centerright Civic Platform. Therefore, these same 6\% increases occurred regardless of government ideology. One may expect events such as the 2008 global economic recession to increase economic grievances, and although economic anti-Semitism did rise in the following years, such attitudes have generally increased over a nearly twenty-year period. Consequently, the data suggest that neither the legal nor public diplomacy responses to anti-Semitism have been particularly effective in reducing attitudes reflecting economic anti-Semitism.

The data in this section demonstrate that although general Polish sympathy toward Jews has increased since the end of the Cold War, levels of religious and economic anti-Semitism have not reflected such improvement - and, in fact, seem to have worsened. In terms of general Polish attitudes toward Jews, the changes reflecting more positive attitudes became most pronounced following the implementation of public diplomacy strategies in 2005. The implementation of legal policies in the 1990's seemed to have far less of an effect, which may be in large part be due to the fact that such policies are more intended to prevent certain violent behaviors, rather than alter perceptions and attitudes - a goal more closely associated with public diplomacy strategy.

Perhaps one explanation as to why Poles tended to have greater sympathy toward Jews over time, yet increasing levels of religious and economic anti-Semitism, is the messaging used in the public diplomacy campaigns. As explained in previous chapters, the primary emphasis of Poland's public diplomacy campaign has been to focus on common connections between Poles and Jews. This has been done via initiatives, such as 
promoting Jewish cultural events and institutions, dialogical forums, educational programs, and other similar measures. There has not been a similar emphasis on dispelling anti-Semitic myths, in particular those relating to religion and the economy. This focus within Poland's public diplomacy messaging may help to explain why Poles have over time developed more sympathetic attitudes towards Jews, yet have an increasing number accept certain religious and economic myths. This discrepancy may expose one of the flaws in Poland's public diplomacy strategy and an area for future improvement.

\section{c. Victimhood Competition}

A unique aspect of anti-Semitism in Poland, that is related to the issue of Holocaust denial, is what is known as victimhood competition. Victimhood competition describes the argument between groups, often ethnic groups, over which group suffered worse during a particular period in history - in this case World War II and the Holocaust. As explained in earlier chapters, some Poles tend to view sympathy regarding the Holocaust as a zero-sum game - either Poles suffered or Jews, but not both. This controversy has become increasingly prominent since 1989 when activists began placing crosses at Auschwitz-Birkenau. By 1998, there were over 240 crosses placed at the site. Proponents of the cross placement argued that the crosses were meant to honor the 100,000 Poles killed at the camp, while critics argued that the crosses were intended to discount the more than one million Jews killed there (Zubrzycki, 2006).

The example of the crosses at Auschwitz-Birkenau is emblematic of the larger issue of victimhood competition in Poland that many psychologists argue spurs ethnic conflict and animosity. Many argue that competitive victimhood reduces trust and 
empathy toward outgroup members (Noor, Brown, and Prentice, 2008). Michal Bilewicz of the University of Warsaw found that Poles who consider their nation an eternal victim of aggression from foreign powers tended to possess anti-Semitic attitudes more often. Bilewicz also found that those who perceived Poles to be more victimized in the past than Jews had significantly more anti-Jewish attitudes (Bilewicz, 2012: 2813).

Notably, this issue of victimhood competition appears to have been increasing in Poland over time. Data show that the number of Poles who acknowledge Jews as the most numerous victims of the wartime period in Poland has decreased since 1992. In $1992,46 \%$ of Poles agreed that Jews were the most numerous victims of WWII and the Holocaust, $38 \%$ in 2002 , and by 2010 only $28 \%$ agreed. Over the same period, the number of Poles who think that ethnic Poles were the most numerous victims of WWII and the Holocaust has increased. In 1992, only $6 \%$ agreed with this claim, this increased to $9 \%$ in 2002 , and up to $15 \%$ in 2010 (ibid.). Bilewicz attributes these numbers to two things. First, the generation of people who remember the Nazi occupation of Poland has been disappearing from Polish society. More than seventy years removed from the Holocaust and WWII, many who directly experienced the period are no longer available to provide first-hand accounts. Second, Holocaust education in the country has not been particularly effective in conveying the extent of destruction to the Jewish community and dispelling myths (ibid.).

These trends are particularly worrisome among Polish youth, a substantial portion of which tend to believe that Jews exploit the Holocaust for their own purposes. Survey results from 2012 showed that $30 \%$ of Polish youth think that Jews abuse Polish feelings of guilt and more than $40 \%$ believe that Jews would like to receive compensation from 
Poland for the Nazi atrocities (ibid.). These accusations tend to align with historical antiSemitic fears of Jews exploiting the Polish people. An important aspect of post-war antiSemitism to remember is that not only Holocaust denial, but also specific evaluations of the Holocaust may be used as a tool to communicate anti-Semitic beliefs or attitudes. Survey results show that there is a portion of Poles who appreciate the fact that the Holocaust ended the thousand-year existence of a large-scale Jewish community in Poland. In a 2010 study, $19.6 \%$ of Poles surveyed agreed with the statement that "Although the Holocaust was a great tragedy, one good thing about it is that there are no more Jews living currently in Poland" (Kucia, 2010). These results demonstrate that while general sympathy among Poles toward Jews has increased since the early 1990's, there are areas of post-war anti-Semitism, and particularly as it relates to victimhood competition, that have increased. These results are particularly noticeable among Polish youth and shows that there is significant room for improvement with regard to Poland's Holocaust education efforts.

\section{d. Anti-Semitic Crimes}

As has been mentioned, the legal responses intended to quell anti-Semitic behavior and hate crimes in Poland have been in place since 1997 with the adoption of the country's modern constitution and penal code. These laws were established with the intent to punish hate speech, incitement, and violence against groups on the basis of religion, ethnicity, nationality, or race. The laws have been in place for approximately two decades, but there has not yet been a study evaluating their actual effects on antiSemitic hate crimes within the country. Perhaps one such reason for this is that Poland lacks credible reporting mechanisms with regard to hate crimes and those data sets that 
exist do not tend to show consistent trends. In the German case, the frequency of antiSemitic crimes and violent attacks has been up and down, following no particular trend over time, but even though this is the case the data from different sources tends to be consistent. The data from the EU Fundamental Rights Agency (EU FRA) and the Ministry of the Interior tended to mirror one another. This has not been the case with regard to Poland. The two main sources of anti-Semitic hate crime data in Poland have been the EU FRA and the Foundation for the Preservation of Jewish Heritage in Poland (FODZ), which submits incident reports on anti-Semitic crimes to Polish authorities. As Figure 6.5 shows, the EU FRA has only been reporting data on anti-Semitic hate crimes in Poland since 2010. This relatively short reporting period makes it difficult to draw concrete conclusions regarding trends in the data.

\section{Figure 6.5}

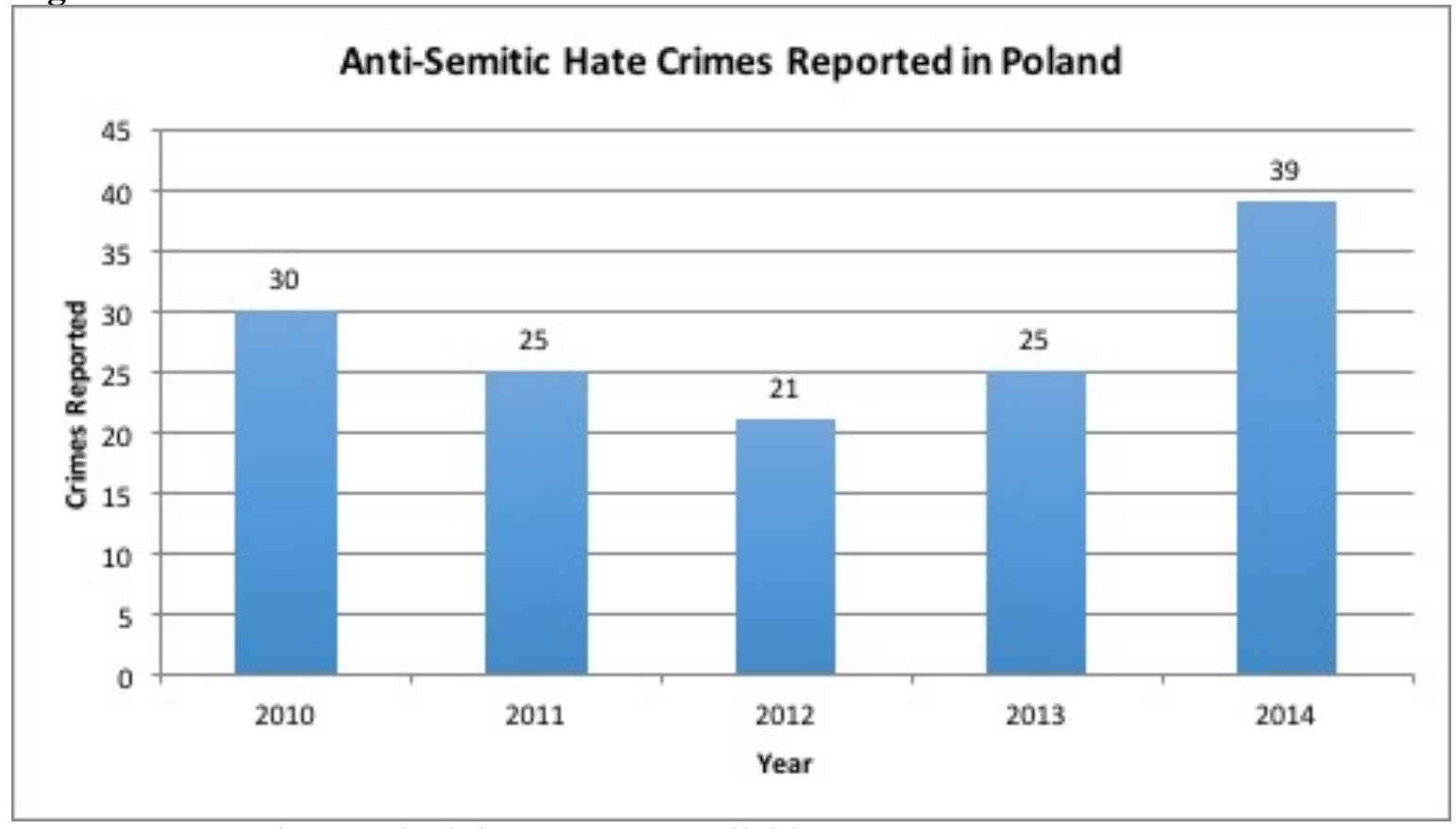

Source: EU Fundamental Rights Agency, available at http://fra.europa.eu/sites/default/files/fra_uploads/fra-2015-antisemitism-update_en.pdf 
The data in Figure 6.5 show that anti-Semitic crimes in Poland decreased from 30 in 2010 to 21 in 2012, but then increased to 39 by 2014. The data collected for these five years do not show any clear trend, perhaps in part due to the relatively short time interval over which the data was collected. Notably, the data in Poland reported by the EU FRA shows a similar spike in anti-Semitic attacks in 2014 to that in Germany. Once again, a likely explanation for this sharp increase is external events, in particular the Israel-Gaza War that took place in the summer of that year. The reporting of anti-Semitic hate crimes in Poland does not categorize perpetrators by ideology, as was the case with the data on Germany, which makes this a difficult area of comparison.

However, it is important to note that the quantity of anti-Semitic crimes reported in Poland is far lower than that in Germany. From 2010 to 2014, Poland experienced between 21 to 39 anti-Semitic hate crimes in a given year - this includes violent attacks, vandalism, and hate speech. In Germany, there were over one thousand anti-Semitic crimes committed in each year over the same time period. There are three likely explanations for this difference in quantity of anti-Semitic crimes. First, Poland has a much smaller Jewish population than Germany. Poland has an estimated Jewish population of between 3,200 and 10,000, whereas Germany has over 100,000 people who belong to Jewish religious communities and an estimated population of over 200,000 who have a Jewish background (Jewish Community Center, 2012) (Crossland, 2012). Consequently, there are simply more Jews in Germany who may be targeted for antiSemitic crimes. Second, definitions of what constitutes an anti-Semitic attack and the ways that data are collected may differ. Definitions of anti-Semitic attacks are indeed subjective and dependent upon the agency or individuals collecting such data. It is 
possible that officials in Poland may be more hesitant to label incidents as anti-Semitic than their counterparts in Germany. Third, it is also possible that the Polish policy responses to anti-Semitism have been more effective in deterring crimes than those in Germany. This last explanation is more difficult to substantiate, because Poland did not track data as far back in time as Germany, and thus it is more difficult to determine the likely effects of public policy on the trends regarding anti-Semitic hate crimes. Nonetheless, at least since 2010, Poland has shown a far lower number of total antiSemitic crimes. Each of these four explanations may contribute to the vast differences in the total number of anti-Semitic crimes in each country.

In addition to the EU FRA, the FODZ also reports data on anti-Semitic incidents in the country. The data from the FODZ is depicted in Figure 6.6. The data from the foundation does go back further in time than that from the EU FRA; however, in the years in which both sources collected data their results differed greatly. 
Figure 6.6

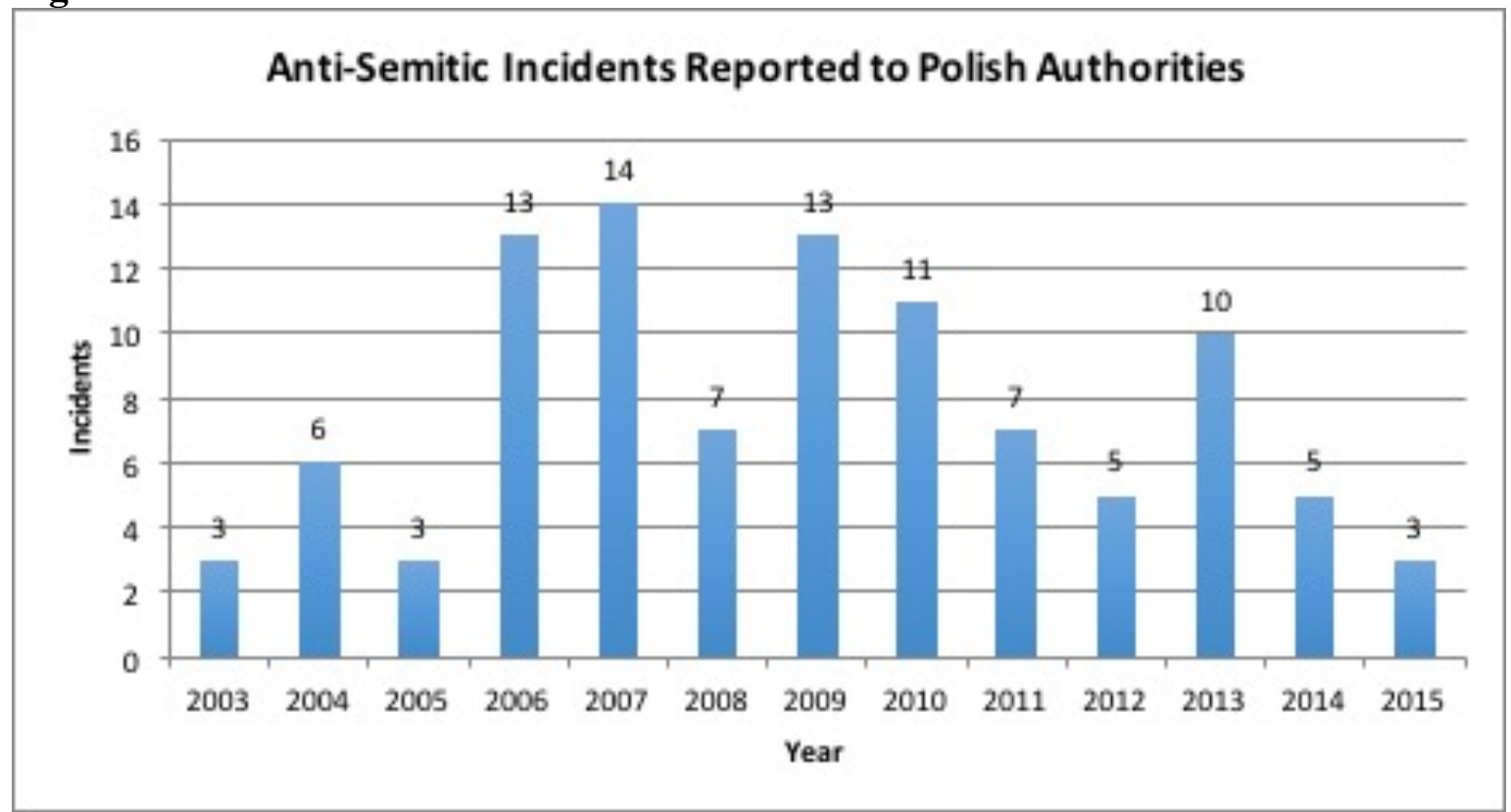

Source: Foundation for the Preservation of Jewish Heritage in Poland, available at http://fodz.pl/?d=5\&id=79\&l=pl

The data from the FODZ tends to report fewer instances of anti-Semitism and this is especially noticeable in 2014 where the EU FRA reported 39 incidents of anti-Semitism and the FODZ only reported 5 such incidents. The general trend from 2010 to 2013 for both groups appears to coincide, but given the vast differences in the data, it is not possible to make definitive statements regarding the numbers or trends of anti-Semitic incidents in the country.

The lack of credible reporting data with regard to anti-Semitic hate crimes in Poland makes it difficult to make a clear determination as to the policy responses' effectiveness in terms of preventing such crimes. There was in fact no central agency tasked with collecting such data, and the data that was collected tended to lack consistency. Recently, however, the Polish government has taken note of these shortcomings and has indeed developed a central agency with the goals of more 
accurately monitoring and reporting on domestic hate crimes. In December 2011, the Ministry of the Interior established the Human Rights Protection Team, which has specifically stated monitoring and reporting domestic hate crimes as part of its central mission (Polish Ministry of the Interior, 2013). A 2014 Human Rights Report by the Polish government stated the purposes of the newly created agency by writing "The key purpose of the activities will be to acquire more detailed information than that obtained so far concerning the specific nature of the monitored incidents, actions taken by law enforcement authorities and the penalties and punitive measures applied. The information gathered will be subject to statistical analysis to provide a detailed picture of the phenomena of racism, xenophobia and hate crimes" (Polish Ministry of Foreign Affairs, 2014). As of 2016, the Human Rights Protection Team had not publicly released reports on these matters. With the eventual release of such data, one would be able to better evaluate the policies toward anti-Semitism and their effects on domestic hate crime incidents. However, in November 2016, the Polish government led by the Law and Justice party dissolved the Human Rights Protection Team and moved its resources into other agencies focusing on European migration and anti-trafficking (Warso and Godzisz, 2016: 4).

\section{e. Revival of Judaism}

As has been the case in Germany, one of the measures taken by the Polish government to improve Polish-Jewish relations and demonstrate progress internationally has been to facilitate, and in some ways even promote, the revival of Judaism within the country. However, it is important to note that the Jewish revival in Poland should not be measured through population increases, but instead by the increase in Jewish cultural 
expression and institutions. This is an important distinction to make. Estimates of Poland's Jewish population have ranged from 3,2000 - 10,000 since the end of the Cold War (Jewish Virtual Library, 2013). Nonetheless, there has been an empirically verifiable increase in Jewish cultural events and organizations since 2000. Some may argue that Polish civil society as a whole has increased in recent years and the increase in Jewish institutions is simply a reflection of this phenomenon. This argument has some validity, however, the Jewish revival is unique due to the role of the Ministry of Foreign Affairs, other government agencies, and international NGOs. No other segment of Polish civil society has been nearly as much of an emphasis of public diplomacy efforts or experienced an increase in cultural activities, institutions, and influence so high compared to a group's proportion of the population.

Poland's emphasis on Polish-Jewish relations in its public diplomacy has not necessarily had increasing the Jewish population as its goal, but rather rejecting the image of Poland representing a Jewish graveyard. This is precisely why the vibrancy of Poland's existing Jewish community and its relationship with Jewish diaspora has been important for the national brand. The promotion of Polish-Jewish relations and the progress that has been made is perhaps best represented through evidence of the vibrancy of today's Jewish culture in Poland and the honoring of Jewish contributions to Polish society as well as the shared history and identity of Poles and Jews. Because of this, Polish agencies have been actively involved in the promotion of the Jewish revival as a means to both enhance relationships abroad and establish credibility to the message that Poland is a modern country that embraces, rather than discourages, diversity. 
One of the most visible examples of the Jewish revival has been in Krakow with noticeable increases in attendance and funding for the annual Krakow Jewish Cultural Festival. The festival actually began in 1988 when twenty-eight-year-old Janusz Makuch, a collector of films about Israel and traditional Jewish music, decided to gather with friends from the local Jewish community at Krakow's Mikro movie theater for a film screening and series of lectures. In its early years, the event lacked funding and could only be held every other year. However, Poland's Ministry of Culture eventually discovered the public diplomacy potential of the event and began offering funding to make the event an annual affair (Tzur, 2013). Since then, the festival has gradually added donors and partner organizations, and in 2009 began organizing year-round workshops, presentations, and concerts (Inside-Poland, 2013). The festival itself is held annually in June with approximately 30,000 people attending, a remarkable number given the fact that Poland's entire Jewish community is only estimated to be between 3,2000 - 10,000. The 2013 budget for the festival reached $\$ 1$ million with most contributions coming from the Polish government and international Jewish organizations (Tzur, 2013) - a partnership strengthened through public diplomacy initiatives. Jewish cultural festivals have, however, not been limited to Krakow. There are now some 16 Jewish cultural festivals in 13 cities throughout Poland (Zubryzycki, 2012: 447). Krakow has nonetheless become the center of the recent Jewish revival with other organizations being created and building off the success of the cultural festival.

Interestingly, these events have not been targeted exclusively toward Polish Jews, but more generally toward anyone with an interest in Jewish culture. In fact, an estimated $85 \%$ of attendees at the Krakow cultural festival are non-Jews (Schaechter, 2007). This 
recent popularity of Jewish culture has also led to increases in Jewish businesses as Poland has become increasingly commercialized. Before World War II, Jewish cafes and markets were a common sight throughout Poland, but after decades of Nazi and communist rule, this was no longer the case. In the early 1990's, Krakow's historically Jewish Kazimierz District had no businesses with roots in Jewish culture or tradition. The first Jewish café opened in 1992, but had little indication of any other Jewish themed establishments in the surrounding area in the years following. This changed, however, as the Jewish Cultural Festival has gained in popularity. By 2012, there were over a dozen Jewish establishments in the Kazimierz District alone (Grollmus, 2012).

These efforts have been notable in terms of returning Jewish culture to a prominent place within Poland's post-communist identity, and, as has been argued, increases in Jewish populations do not tell the full story regarding Poland's Jewish revival, nonetheless there have been notable increases in conversions to Judaism in the past decade. In Warsaw, Beit Warsaw, a Reformist Judaism congregation, has overseen over 100 conversions since it began offering courses in 2003 with another 80 members with Jewish roots considering conversion (Tzur, 2012). Some congregations have begun offering "Judaism Step-by-Step" courses that allow Poles to learn about Judaism with a possibility to convert. According to Jewish leaders, conversion rates have been on the increase, and, as Krakow Jewish Community Center director Jonathan Ornstein describes, the increases in conversion to Judaism has been dubbed the "Jewish Jewish Revival." Ornstein goes on to state "You are talking about a community that was frozen. It went underground. And now it's reemerging" (Grollmus, 2012). Many of those who have converted or are considering conversion are those Poles who have discovered 
Jewish roots in their own families that their parents or grandparents may have masked during the Holocaust or communist rule. So as there have not yet been remarkable increases in Poland's total Jewish population, the increased prevalence of Jewish culture may likely lead to increases in conversions and consequently growing the population and religiosity of Jewish believers.

\section{Conclusion}

The data from this chapter demonstrate that in some areas where the Polish government has placed the greatest emphasis in terms of healing Polish-Jewish relations, there have been positive results, in particular improving general Polish attitudes toward Jews. The general theme of Poland's public diplomacy campaign since 2005 has been to emphasize common connections between Poles and Jews - both historically and culturally. This has been done through cultural exchanges, holding dialogical forums, promoting Jewish cultural events, and emphasizing Jewish contributions to Polish society. The data in Figure 6.1 showed that since the implementation of this strategy, survey results of Poles have begun to reflect greater sympathy and less antipathy toward Jews. However, despite these improvements in general attitudes, other survey data has shown increases in religious and economic anti-Semitism within the country. This discrepancy indicates that while the focus on common connections between Poles and Jews may have made Poles more sympathetic toward Jews, the public diplomacy campaign has not necessarily been successful, or well-focused enough, with regard to dispelling anti-Semitic myths that have been perpetuated in the country for centuries. Thus, the public diplomacy campaign could be improved with more emphasis on such issues. 
Another area where Poland's public diplomacy could be improved is in addressing the concept of victimhood competition. Survey data has shown since 1992 that greater percentages of Poles have been downplaying the effects of the Holocaust on the Jewish community. This may in part be due to inadequacies in the country's Holocaust education efforts. Also worrisome are survey data among the country's youth that show $30 \%$ believe Jews abuse feelings of Polish guilt. This concept of victimhood competition has not been specifically addressed in Poland's public diplomacy despite the fact that this has been an important aspect of post-war anti-Semitism in the country.

From the available data, it is difficult to ascertain the effectiveness of Poland's policies with regard to anti-Semitic crimes committed in the country, as these data have not been collected reliably nor consistently over a long enough period. Without a central agency to collect such data by applying the same hate crime definition, and given that the data from two main sources currently available vary widely, it is not possible to draw concrete conclusions in this area. While the Polish government appeared to have taken note of this inadequacy and in 2014 tasked the Human Rights Protection Team within the Ministry of the Interior to monitor hate crimes in the country and report credible statistics, this agency was dissolved in November 2016 by the ruling Law and Justice government. As of 2017, no such reports have been published making it difficult to fully evaluate policy effectiveness with regard to anti-Semitic crimes (Warso and Godzisz, 2017: 4).

As with the German case, Poland has also experienced a recent revival of Judaism within the country. However, the Jewish revival in Poland is less defined by increases in the actual Jewish population, but rather an increase in Jewish cultural expression and 
institutions. The revival can most clearly be seen in the increases in cultural festivals, Jewish community centers, and Jewish-themed businesses. And although the revival is primarily defined by these cultural expressions and institutions, there has also been evidence of some Poles converting to Judaism due to factors such as increased interest in the religion's history in Poland and discoveries of Jewish roots within many families.

Taken together, the information in this chapter indicates that Poland's policies toward anti-Semitism have made progress in some areas, such as increased sympathy among Poles toward Jews, as well as increases in Jewish cultural expression and institutions. This chapter has also revealed certain limitations to Poland's approach and potential areas for improvement, including greater emphasis on dispelling anti-Semitic myths, addressing the issue of victimhood competition, and consistently collecting data on anti-Semitic hate crimes. The following Discussion and Conclusion will offer some final insights as to the connections between the German and Polish cases and areas where further investigation is needed.

\section{References}

Ambrosewicz-Jacobs, Jolanta (2013). Antisemitism and Attitudes Toward the Holocaust: Empirical Studies from Poland. Proceedings of the Antisemitism in Europe Today: the Phenomena, the Conflicts Conference; 8-9 November, Berlin. Jewish Museum of Berlin, pp. 1-9.

Bilewicz, Michal (2012). Anti-Semitism in Poland: Economic, Religious, and Historical Aspects, Journal for the Study of Anti-Semitism (4): 2801-2820.

Borger, Julian and Jeevan Vasagar (2011). A Jewish Renaissance in Poland, The Guardian, online publication April 6: http://www.guardian.co.uk/world/2011/apr/07/jewish-renaissance-poland. 
Center for Research on Prejudice (2013). Anti-Semitism in Poland 2013: Research Report based on Polish Prejudice Survey II, http://cbu.psychologia.pl/uploads/f_winiewski/PPS2\%20raporty/raport_antysemit yzm_ang.pdf accessed on 2 November 2016.

Coordination Forum for Countering Anti-Semitism (2014). Poland Poll Reveals Stubborn Anti-Semitism Amid Jewish Revival Hopes, 18 January: http://antisemitism.org.il/article/84353/poland-poll-reveals-stubbornantisemitism-amid-jewish-revival-hopes accessed on 22 October 2016.

Crossland, David (2012). We Can Resume Our Common History: New Paper Covers Revival of German Jewish Life, Der Spiegel. 4 January, http://www.spiegel.de/international/germany/we-can-resume-our-commonhistory-new-paper-covers-revival-of-german-jewish-life-a-807118.html, accessed on 7 September 2016.

EU Fundamental Rights Agency (Various Years). Antisemitism: Overview of Data Available in the European Union, http://fra.europa.eu/sites/default/files/fra_uploads/fra-2015-antisemitismupdate_en.pdf, accessed on 28 May $201 \overline{6}$.

Eurobarometer (2012). Discrimination in the EU in 2012, http://ec.europa.eu/public_opinion/archives/ebs/ebs_393_fact_pl_en.pdf accessed on 2 November 2016.

Foundation for the Preservation of Jewish Heritage in Poland (Various Years). Monitoring of Anti-Semitism in Poland, http://fodz.pl/?d=5\&id=79\&l=pl accessed on 2 November 2016.

Grollmus, Denise (2012). Poland's Real Jewish Revival, Tablet, online publication November 26: http://www.tabletmag.com/jewish-life-andreligion/116890/polands-real-jewish-revival, accessed 18 November 2016.

Inside-Poland (2013). Krakow's Festival of Jewish Culture - 25 Years on, http://insidepoland.com/t/krakows-festival-of-jewish-culture-25-years-on/, accessed 18 November 2016.

Jarosz, Andy (2013). New Life in Krakow's Jewish Quarter, BBC, online publication February 17: http://www.bbc.com/travel/feature/20130126-new-life-in-krakowsjewish-quarter, accessed 18 November 2016.

Jewish Community Center (2012). Building a Jewish Future in Krakow, https://jewsofkrakow.wordpress.com/tag/jews-in-poland/, accessed 18 July 2013. 
Jewish Virtual Library (2013). Virtual Jewish History Tour: Poland, http://www.jewishvirtuallibrary.org/jsource/vjw/Poland.html, accessed 18 November 2016.

Kucia, M. (2010). Antysemityzm w Polsce a.d. 2010 [Antisemitism in Poland A.D.2010]. Warsaw: OBOP

Institute for National Remembrance (2017). Home Page, https://ipn.gov.pl/en, accessed 1 February 2017.

Museum of the History of Polish Jews (2013). About the Museum, http://www.jewishmuseum.org.pl/en/about-museum, accessed 19 November 2016.

National Electoral Commission of Poland (2016). Election Results, http://pkw.gov.pl/ accessed on 22 October 2016.

Noor, M., Brown, J. R., \& Prentice, G. (2008). Precursors and mediators of intergroup reconciliation in Northern Ireland: A new model. British Journal of Social Psychology 47, 481-495.

Polish Ministry of the Interior (2013). Human Rights Protection Team, https://mswia.gov.pl/en/document/ways-of-acquiring-poli/865,Human-RightsProtection-Team.html, accessed 25 November 2016.

Polish Ministry of Foreign Affairs (2014). Universal Periodic Review - Human Rights Council $25^{\text {th }}$ Session, https://www.msz.gov.pl/resource/428cdaf1-aa94-425f-ac11f19f7da349bd:JCR, accessed on 25 November 2016.

Public Opinion Research Center (2015). Annual Public Opinion Survey, http://www.cbos.pl/SPISKOM.POL/2015/K_014_15.PDF accessed on 1 November 2016.

Schaechter, Rukhl (2007). Krakow Jewish Fest Features Notable Absence: Jews, The Jewish Daily, online publication July 13: http://forward.com/articles/11142/krakow-jewish-fest-features-notable-absencejews/, accessed 18 November 2016.

Sulek, Antoni (2012). Ordinary Poles Look at the Jews, Eastern European Politics and Society 26 (2): 425-444.

Syal, Rajeev (2015). Polish Defence Minister Condemned over Jewish Conspiracy Theory, The Guardian, 10 November: https://www.theguardian.com/world/2015/nov/10/polish-defence-ministercondemned-over-jewish-conspiracy-theory accessed on 22 October 2016. 
Tzur, Nissan (2012). Recent Converts Offer a Glimpse of Judaism's Appeal in Poland, The Times of Israel, online publication November 4: http://www.timesofisrael.com/recent-converts-offer-a-glimpse-of-judaismsappeal-in-poland/, accessed 19 November 2016.

Tzur, Nissan (2013). 25 ${ }^{\text {th }}$ Jewish Culture Festival Brings Sabra Style to Krakow, Jerusalem Post, online publication June 30: http://www.jpost.com/Arts-andCulture/Arts/25th-Jewish-Culture-Festival-brings-sabra-style-to-Krakow-Poland318257 , accessed 18 November 2016.

Warso, Zuzanna and Piotr Godzisz (2017). Information on the Recent Challenges Faced by Human Rights Defenders and Civil Society in Poland. Helsinki Foundation for Human Rights, online publication November: http://www.hfhr.pl/wpcontent/uploads/2016/11/HRD-report-30112016-FIN.pdf, accessed 1 February 2017.

Zubrzycki, Genevieve (2006). The Crosses of Auschwitz: Nationalism and Religion in Post-Communist Poland. Chicago: University of Chicago Press.

Zubrzycki, Genevieve (2012). Religion, Religious Tradition, and Nationalism: Jewish Revival in Poland and 'Religious Heritage' in Quebec, Journal for the Scientific Study of Religion 51 (3): 442-455. 


\section{CHAPTER VIII}

\section{CONCLUSION}

This dissertation has sought to answer the question: Have state policies been effective in reducing levels of anti-Semitic attitudes and incidents in Germany and Poland? It has attempted to do so by addressing the historical problem of anti-Semitism in both countries, examining the contemporary policies employed to counter the problem, and, finally, evaluating the effectiveness of the measures taken. The preceding chapters have covered these issues in detail through historical and policy analysis. This section will discuss some of the major themes in the two cases, provide analysis of the theoretical and practical implications of the study, as well as propose avenues for future research.

\section{Major Themes and Patterns}

The historical development of anti-Semitism in both the German and Polish cases followed similar paths of development with each country experiencing the four primary manifestations of anti-Semitism over time. In both cases, religious anti-Semitism preceded all other forms. Accusations of blood libel and deicide, along with other misunderstandings of Jewish religious practices, motivated many of the early persecutions of Jews in Central Europe. Following the First Crusade, Jews in Central Europe were often restricted to employment in socially inferior sectors such as moneylending and tax collection - in large part due to Catholic prohibitions on usury. This development led to an often adversarial relationship between Christian debtors and Jewish creditors forming the basis for the next manifestation - economic anti-Semitism. Therefore, economic anti-Semitism was, in a way, borne out of religious anti-Semitism. The depiction of greedy Jewish bankers among many Germans and Poles from the 
Middle Ages onward has often led to resentment and scapegoating for various societal ills. Such attitudes have been a continuing source of conspiracy theories, such as The Protocols of the Elders of Zion, and provided a common justification for Jewish persecution during times of economic turmoil.

In the nineteenth century, a combination of pseudo-scientific theories, such as eugenics, and a rise in ethnic nationalism led to a new manifestation of anti-Semitism taking shape - racial anti-Semitism. At the core of racial anti-Semitism is the belief that one's Jewishness is not only determined by one's beliefs, but also one's blood. In many of the pseudo-scientific theories of the time, the Jewish race was often considered inferior. After World War I, many Germans, in particular the Nazi Party, scapegoated Jews for their loss in the war and propagated ideas of an ideal, ethnically homogenous state - an ideal that did not include Jews. At the same time, many Catholic nationalists in the newly created independent Polish state sought to establish a Catholic state - an ideal that also did not include Jews. These factors played a major role in sparking the violent anti-Semitism that led to expelling great numbers of Jews and eventually exterminating millions in the Holocaust.

The fourth and most recent manifestation of anti-Semitism, also present in both countries, is political anti-Semitism. Political anti-Semitism includes numerous conspiracy theories, many relating to Zionist plots to undermine governments, as well as Holocaust denial and, particularly in Poland, the notion of victimhood competition. This manifestation often perpetuates theories that depict Jews as attempting to achieve gains by illegitimate means, such as exaggerating, or even making up, the Holocaust to receive international sympathy for the Zionist movement or undermining governments through 
various means. These manifestations have centuries long histories in both countries, have led to long periods of violence and persecution, and have become a problem that both the German and Polish governments have recently decided to address to help improve their respective country's international reputation and standing.

In the post-Cold War period, both Germany and Poland had motivations to address both the accusations and realities of historical and modern anti-Semitism. Each country has taken a similar approach in terms of implementing both legal and public diplomacy measures to counter the problem; however, the methods and chronology tend to differ in a few ways. In the German case, legal measures have included punishments for certain forms of hate speech, incitement, and Holocaust denial, easing immigration restrictions on Eastern European Jews, and granting Judaism full legal status with certain protections. Germany's public diplomacy measures include assisting Jewish civil society organizations, promoting education initiatives for youth, and countering far right group messaging and membership. Legal measures in Poland have included punishments for certain forms of hate speech, incitement, and Holocaust denial, establishing a central organization to investigate such crimes, allowing some Jews of Polish origin to return, and granting Judaism full legal status. Poland's public diplomacy has been primarily concerned with emphasizing a message demonstrating historical connections between Poles and Jews, providing support to Jewish cultural organizations, and correcting mischaracterizations regarding the Holocaust.

The initiatives listed above provide the contours of each country's strategy to counter anti-Semitism. The strategies overlap in a number of ways: both countries have laws prohibiting certain anti-Semitic speech, incitement, and Holocaust denial; provide 
various means of support to domestic Jewish communities; and partner state and civil society organizations through public diplomacy initiatives. These strategies also differ in two major of ways: whereas Germany has eased Jewish immigration restrictions to help rebuild domestic Jewish communities, Poland has not done so to near the same extent; and while Germany has focused on countering right wing ideology and membership, Poland has focused on emphasizing common connections between Poles and Jews. In analyzing the effectiveness of each state's policies, one is able to see a few important patterns.

Perhaps the most notable result from both the German and Polish cases has been the overall decline in general anti-Semitic attitudes in both countries. This was especially evident in Figures 5.3 and 6.1. General anti-Semitic attitudes in each country have declined by nearly half in each case since the early 2000 's. In Germany, this was accompanied by a consistent decline in far right group membership over time. The data in other areas is less definitive. The crime data in both cases tends to vacillate from year to year and does not follow any particular trend. Consequently, the results in this area tend to be mixed and less successful than in other areas, such as attitudes.

Both Germany and Poland have experienced recent revivals of their domestic Jewish communities, in part due to certain policy initiatives; however, each revival has one major difference. Whereas the Jewish population in Germany has increased drastically since 1990, in large part due to the easing of restrictions on Jewish immigration from Eastern Europe; the Jewish revival in Poland can be considered more of a cultural revival with a much smaller domestic Jewish population. These different approaches to policy initiatives provide a feasible explanation for this major difference. 
While Germany loosened immigration restrictions on Eastern European Jews with a primary aim of rebuilding a domestic Jewish community that existed for centuries prior to the Holocaust, Poland has focused its public diplomacy on emphasizing common connections between Poles and Jews, which has in turn led to a focus and increased popular interest in Jewish history and culture. So while both countries have experienced increases in the vibrancy of their respective Jewish communities, the German revival is marked primarily by large increases in population, and the Polish revival is marked by large scale increases in the display of Jewish culture.

\section{Theoretical Findings}

Anti-Semitism is a term without a universally agreed upon definition; however, this dissertation has sought to develop a concise definition that takes into account the various manifestations of hatred toward Jews throughout history. The definition proposed in this dissertation is as follows: "hostile attitudes or attacks targeting Jewish people, symbols, or interests based on religious, economic, racial, or political grounds." AntiSemitism is most often measured using survey research assessing attitudes and crime data regarding attacks on Jewish people and property. Furthermore, the historical manifestations of anti-Semitism have developed from religious, economic, racial, and political hatred and grievances. The academic literature on the subject varies in terms of how many and which type of manifestations exist, but, as this dissertation has argued through historical analysis, these four categories most accurately and concisely capture the historical development of the problem. 
The implementation of legal measures to counter anti-Semitism raises some important questions about the role of the state and its interest with regard to minority groups and religions. In both the German and Polish cases, the state decided to enact legislation that placed certain limitations on hate speech and incitement. The language in such legislation is often broad, restricting certain speech that disparages or incites violence against groups based on nationality, race, ethnicity, or religion. In these cases, Germany and Poland also restrict speech that minimizes or denies the crimes committed under National Socialism. This is an important factor and one that is rooted in each country's respective experience and history. The broad nature of this legislation and its tension with the concept of free speech can potentially make such cases difficult to prosecute. Each country has tasked different institutions with investigating and prosecuting such crimes, but in these cases the state has nonetheless determined that it has a vested interest in policing and prosecuting certain forms of speech to counter the propagation of anti-Semitic and National Socialist ideas.

Considering the magnitude of displaced persons due to World War II, the Holocaust, and various other persecutions, issues regarding immigration and repatriation have been complex in the cases of Germany and Poland. In both cases, the state has adopted legislation allowing former citizens who were displaced to regain their citizenship; however, the criteria and motivations for doing so can be ambiguous. In Poland, those who can prove that they are of "Polish origin" may apply for citizenship if they meet certain other conditions. In Germany, former German citizens are offered means of regaining their citizenship; however, German immigration law was loosened in the early 1990's in a way that allowed many Soviet Jews a means of acquiring citizenship 
as well. The German government stated at the time that these measures were implemented in part to help restore domestic Jewish communities and improve relations between Germans and Jews. Consequently, Germany has become one of the primary destinations for immigrant Jews and has experienced dramatic increases in its domestic Jewish population. Poland, on the other hand, has not loosened its immigration laws to the same extent nor has the government proposed using immigration to help restore domestic Jewish communities. The issues surrounding immigration and repatriation can be telling in terms of each state's position on which people are deserving of citizenship and the goals of immigration policy and its relationship to domestic Jewish communities. While Germany has used immigration as a means to help rebuild domestic Jewish communities, this has not been a stated goal in the Polish case.

Granting legal status to Judaism has also been an important legal development in both of these cases. While both Germany and Poland already have constitutional protections in place for freedom of religion, granting full legal status is necessary for a religious community to obtain certain financial and security benefits. In Germany, legal status allows religious communities to reap tax benefits, security resources, as well as state funding for certain selected projects. In Poland, the Jewish community also receives similar benefits in these areas. While neither state has an established state religion, Jewish cultural and religious institutions have benefitted from additional protection and funding since obtaining full legal status.

This dissertation offers a unique theoretical finding with regard to public diplomacy - namely, the importance of domestic engagement when targeted to address an issue such as anti-Semitism. Much of the literature on public diplomacy focuses on the 
concept of "promotion" and a country's efforts to emphasize the positive aspects of its culture, political values, and foreign policies. However, events such as genocide can overwhelm international perceptions about a particular country and thus need to be addressed publicly. In order for international messaging on such issues to be credible, these countries must first demonstrate domestic progress on these issues. This element of credibility is an important link between the domestic and international spheres. The cases of Germany and Poland and their public diplomacy efforts with regard to anti-Semitism are a prime example of this linkage

These countries' approaches to countering anti-Semitism are certainly multifaceted involving numerous organizations - both governmental and nongovernmental. To be sure, the state has played a role in facilitating and financing many of the contemporary efforts, but non-governmental institutions often specialize in particular areas and establish relationships with other groups inside and outside of the country. The concept of domestic engagement in public diplomacy is uncommon in the contemporary literature on the subject, but anti-Semitism is one issue where this has nonetheless been the case.

\section{Practical Implications}

This dissertation has shown that the policies implemented in the German and Polish cases have been more effective in achieving some goals than others. As of 2017, the policies intended to counter anti-Semitism have tended to be more effective in affecting general attitudes toward Jews and helping revive domestic Jewish communities than they have in reducing levels of anti-Semitic crimes. So to answer the central research question, one could say that indeed the state policies toward anti-Semitism have 
been effective in reducing general anti-Semitic attitudes and less so in reducing antiSemitic incidents.

In both cases, general anti-Semitic attitudes declined by approximately half over the time periods measured. These declines, especially in the Polish case, tended to follow the implementation of public diplomacy initiatives that were largely aimed toward achieving this goal. In Germany these declines in general anti-Semitic attitudes were also marked by relatively consistent declines in far right group membership - an area that such campaigns tended to focus. In Poland, while general anti-Semitic attitudes tended to decline over time, there has been less progress in reducing the percentages of the population who believe certain religiously and economically anti-Semitic myths.

Dispelling such myths has not tended to be a focus of the country's public diplomacy and is an area in clear need of improvement.

While Germany has experienced some declines in the numbers of anti-Semitic crimes since around 2006/2007, these declines have not been consistent. An overwhelming number of such incidents have been perpetrated by those from a far right ideology and the country has responded by targeting most initiatives toward such groups. As stated, general anti-Semitic attitudes in the country have declined over time, but the lack of similar progress in preventing crimes shows an area in need of policy improvement. Programs such as Exit-Deutschland have been focused on reaching out to and reforming those most predisposed to committing anti-Semitic crimes and the state has recently engaged in close partnership with the program through both organizational and financial support. Such partnership has only been in place since 2013 and its effectiveness will be important to watch in subsequent years. In Poland, it is more 
difficult to fully evaluate policy effectiveness with regard to anti-Semitic crime due to the scarcity of data on the subject. Such data is necessary to help determine which areas have been most successful and which need more improvement. The Law and Justice government's decision in November 2016 to dissolve the Human Rights Protection Team, which had been tasked with collecting such data, provides a setback in evaluating these policies. Greater attention in this area is necessary to evaluate and offer improvements to the relevant policy initiatives.

In each case, the country has experienced a revival of its domestic Jewish community - Germany primarily in terms of population and Poland primarily in terms of the expression and popularity of Jewish culture. These revivals were not necessarily driven by the state, but each state has in part been responsible for facilitating conditions necessary for a Jewish revival to take place. In Germany, a loosening of immigration laws for Eastern European Jews has allowed the domestic Jewish population to grow rapidly. These measures were taken with an explicit intent to help revive domestic Jewish communities that had been decimated by the Holocaust. In Poland, the government has helped facilitate the revival of Jewish culture by helping finance Jewish cultural festivals, museums, and preserving and renovating Jewish historical sites. Such revivals serve the public diplomacy goals of each country by demonstrating progress and reconciliation with the Jewish community. These efforts have been complemented by more general outreach to Jewish communities not only domestically but abroad as well. German and Polish Jews are potentially credible messengers who can speak to this sort of domestic progress and help heal each country's reputation and image abroad. These sorts of outreach and policy initiatives have been important components to each country's 
relationship with the Jewish community and public diplomacy goals - both domestically and internationally.

\section{Policy Recommendations}

While both countries have demonstrated some progress on the issue of antiSemitism as a result of their existing policies, there are nonetheless areas for potential improvement. As has been stated, the data demonstrates that the policies targeting antiSemitism in each country have been more effective in certain areas than others. On the whole, general anti-Semitic attitudes have declined in each country over time. Each country has also experienced a revival of their respective Jewish communities. But there are still areas where either there is a lack of information or results have been less successful. This section will identify a few areas where policy initiatives can most readily be improved and provide relevant recommendations.

The first area for policy improvement is with regard to data collection. In the Polish case, hate crime data tends to be scarce and unreliable. This makes it difficult to not only evaluate the success of policy initiatives, but also to develop policies that target the most important issues and audiences. And while the data in the German case tends to be more prevalent and reliable, there are still areas in which it is lacking. For example, neither case presents detailed demographic data with regard to hate crimes nor attitudes. The data available only tends to measure general attitudes and does not go in depth with regard to the perpetrators and victims of crimes. This is especially important in a case such as Germany that has an increasingly diverse population. A one-size-fits-all approach to combatting anti-Semitism may not be as effective as one that identifies the subtleties and different manifestations of the problem among different demographic groups. For 
example, the anti-Semitic myths and messaging among Muslim migrants in Germany likely differs from the anti-Semitic myths and messaging among members of far right political parties and groups. Therefore, the state responses would likely be more effective by targeting its own messaging to address these differences. The 2016 decision of the Law and Justice party in Poland to dissolve the Human Rights Protection team has reduced the likelihood for improved data collection in that case, and factors such as privacy concerns in Germany make it difficult to identify variations of anti-Semitism among different demographic audiences. Nonetheless, a stronger base of knowledge and data is the foremost factor in better developing policies that can more directly and effectively address the audiences and manifestations of anti-Semitism in each case.

A better understanding of the underlying problems of anti-Semitism also makes it possible to more carefully and directly target policies to the areas where they will be most effective. While there is certainly more information and study needed on the problem of anti-Semitism in each country, the existing data presents a few areas where the German and Polish states can already improve their policy implementation. In the German case, the data shows general anti-Semitic attitudes declining over time, but xenophobic attitudes tend to be much more prevalent, especially in the former East Germany - a stronghold for far right parties and groups. As has been mentioned, these rates of xenophobia remain a significant concern for Germany's domestic Jewish community as some $90 \%$ are indeed immigrants. Combatting xenophobia is likely to become more difficult and complex in the German case given recent influxes of Middle Eastern refugees and migrants, but ensuring that efforts to combat anti-Semitism go hand-in-hand 
with efforts to combat xenophobia would likely provide a more effective and efficient means to reducing threats to the domestic Jewish community.

In the Polish case, like in the German, data has also shown improvement in terms of reducing general anti-Semitic attitudes. However, there have been notable increases in the percentages of Poles believing in certain anti-Semitic myths relating to blood libel, deicide, and economic anti-Semitism. These myths have been prevalent in Poland for centuries, yet Polish public diplomacy messaging does not tend to focus on countering these myths to any great extent. Poland's messaging often emphasizes common connections between Poles and Jews and this messaging has been accompanied by increasing rates of sympathy toward Jews among Poles. A similar focus on countering anti-Semitic myths is perhaps the most pressing need in terms of addressing anti-Semitic attitudes within the country. Poland has the infrastructure in place to develop and disseminate such messaging through organizations such as the Institute for National Remembrance, the Ministry of Foreign Affairs, and various other cultural institutions such as the Museum of the History of Polish Jews. These organizations already work to correct mischaracterizations of Jewish history in the country and improve Polish-Jewish relations more generally. Improving in this area is perhaps the simplest and most immediate improvement that can be made in the Polish state's approach to countering anti-Semitism within the country.

While both Germany and Poland continue to grapple with the challenges and trauma of the Holocaust, it is notable that each country has tended to take its own individual approach to countering anti-Semitism and coping with the past. Although both countries share a common history in many respects, these two countries tend to have 
competing approaches to these issues rather than collaborative. Both countries share some similar themes in their approach, such as providing Judaism with certain legal protections, passing legislation to combat hate crimes, and engaging with NGOs to conduct public diplomacy; however, there has been little coordination between the two governments. Given the transnational nature of the anti-Semitism problem, there are indeed opportunities for these governments to coordinate on certain issues and demonstrate a unified approach to the problem. Although there remain some lingering tensions between the two countries with regard to World War II and its aftermath, one means of addressing such tensions and opening a dialogue would be the establishment of an exchange program between the two countries for the purposes of addressing the common threats of extremism, anti-Semitism, and xenophobia, finding common ground, and developing potential solutions. Each country already shares exchange agreements with other countries for these purposes, notably the Polish Ministry of Foreign Affairs agreement with the American Jewish Committee, but there is not yet an established program between Germany and Poland for these purposes. Involving influential policymakers, academics, and other public figures in such an arrangement would be an important step in relieving some of the tensions between the countries and developing solutions to a problem that has and continues to deeply affect both.

\section{Avenues for Future Research}

As the policies examined throughout this dissertation remain relatively recent, monitoring them in the future will provide greater insight into their long term effectiveness, especially as data becomes more plentiful in this area. Both countries have organizations actively tracking survey data on anti-Semitic attitudes and Germany has 
rather detailed crime data to evaluate - the lack of hate crimes data in the Polish case tends to be a limitation to this research, so the addition of an agency or NGO tasked with collecting accurate data would be an important step. The dynamism and diversity of organizations and partnerships that make up each country's public diplomacy is an area worthy of further investigation. This dissertation has sought to examine the general approach to each country's public diplomacy, but a closer focus on these organizations and their changes over time provides opportunities for research. Although the legal measures in each country have not experienced many changes since the late 1990's and early 2000 's, this, too, remains an area worthy of future observation.

In addition to examining these two cases, the analysis of other post-genocide counties/regions will help add to the comparative perspective on how to most effectively deal with similar problems. This is true in comparing both the theoretical and practical implications of public diplomacy and legal measures. Countries such as Turkey, Serbia, Cambodia, Guatemala, Rwanda, and others provide areas for comparison in terms of how these countries have attempted to resolve domestic tensions and improve international perceptions. Not all countries have approached these issues in the same way, so it would be useful to examine these differences to help find which measures have been most and least effective over time.

Pursuing these avenues of future research will help develop our understanding of the ways to reduce religious and ethnic hatred more generally. Anti-Semitism has been an historical problem in both the German and Polish cases and has marked each country's history and reputation as a result of the Holocaust. But there are many other forms of religious and ethnic hatred that exist around the world, so further examining their 
manifestations and the measures to combat them may work to strengthen public policy and reduce violence and extremism going forward. This dissertation has offered a thorough examination of the efforts put forth by two countries marked by the deadliest genocide in human history. By examining these cases further and comparing them to other relevant cases around the world, we may discover improved ways to combat and prevent the forms of hatred and violence that continue to remain a problem throughout much of the world. 
VITA

\section{THOMAS JUST}

Born, Milwaukee, Wisconsin

$2005-2009$

B.A., German and International Studies

Baylor University

Waco, Texas

$2009-2011$

M.P.P., International Relations and Economics

Pepperdine University

Malibu, California

$2011-2012$

Legislative Correspondent

United States House of Representatives

Washington, District of Columbia

$2012-2017$

Doctoral Candidate

Florida International University

Miami, Florida

2015

Award, Best Graduate Student Paper

Florida Political Science Association

2017

Award, Dissertation Year Fellowship

Florida International University

2017

Award, Youth Ambassador for Peace

UNESCO

\section{PUBLICATIONS AND PRESENTATIONS}

Just, Thomas (2016). "Promoting Russia Abroad: Russia's Post-Cold War National Identity and Public Diplomacy," Journal of International Communication 22(1): 82-95.

Just, Thomas (2015). "Public Diplomacy and Domestic Engagement: The Jewish Revival in Poland," Place Branding and Public Diplomacy 11(4): 263-275.

Just, Thomas (2015). "Post-Communist Recovery and the State: The Case Studies of Poland and Ukraine," Florida Political Chronicle 24(1): 41-54.

Just, Thomas (2011). "The Political and Economic Implications of Great Lakes Invasive Species,” Pepperdine University Policy Review 5(1): 5-15. 
"Contemporary State Responses to Anti-Semitism in Germany and Poland," International Studies Association Annual Meeting, Baltimore, MD, February 2017.

“The Imagery of Political Extremism," Florida Political Science Association Annual Meeting, Lakeland, FL, April 2016.

“The Public Diplomacy of German-Jewish Relations," International Studies Association Annual Meeting, Atlanta, GA, March 2016.

"The Uneasy Alliance of Anti-Semitism: Radical Islam and the Far Right in Germany," International Studies Association - South, Tampa, FL, October 2015.

"Branding Extremism: Nazi and Contemporary Islamist Movements," Aladdin Project UNESCO International Summer University, Mustafapasa, Turkey, July 2015.

"Post-Communist Recovery and the State: The Case Studies of Poland and Ukraine," Florida Political Science Association Annual Meeting, University of Central Florida, Orlando, FL, March 2015.

"Promoting Russia Abroad: Russia's Post-Cold War National Identity and Public Diplomacy," International Studies Association Annual Meeting, New Orleans, LA, February 2015.

"National Identity and Reconciliation: The Revival of Poland's Jewish Community," International Studies Association - Collegium Civitas Joint Eurasia Conference, Warsaw, Poland, June 2014.

"Public Diplomacy and National Identity Formation: The Jewish Revival in Poland," International Studies Association Annual Meeting, Toronto, Canada, March 2014.

"The Most Powerful Man in the World: Presidential War Powers and the United Nations," Florida Political Science Association Annual Meeting, Flagler College, St. Augustine, FL, March 2014.

"Waging Peace: Leipzig's Peaceful Revolution," Honors Scholar Symposium, Baylor University, Waco, TX, April 2009. 